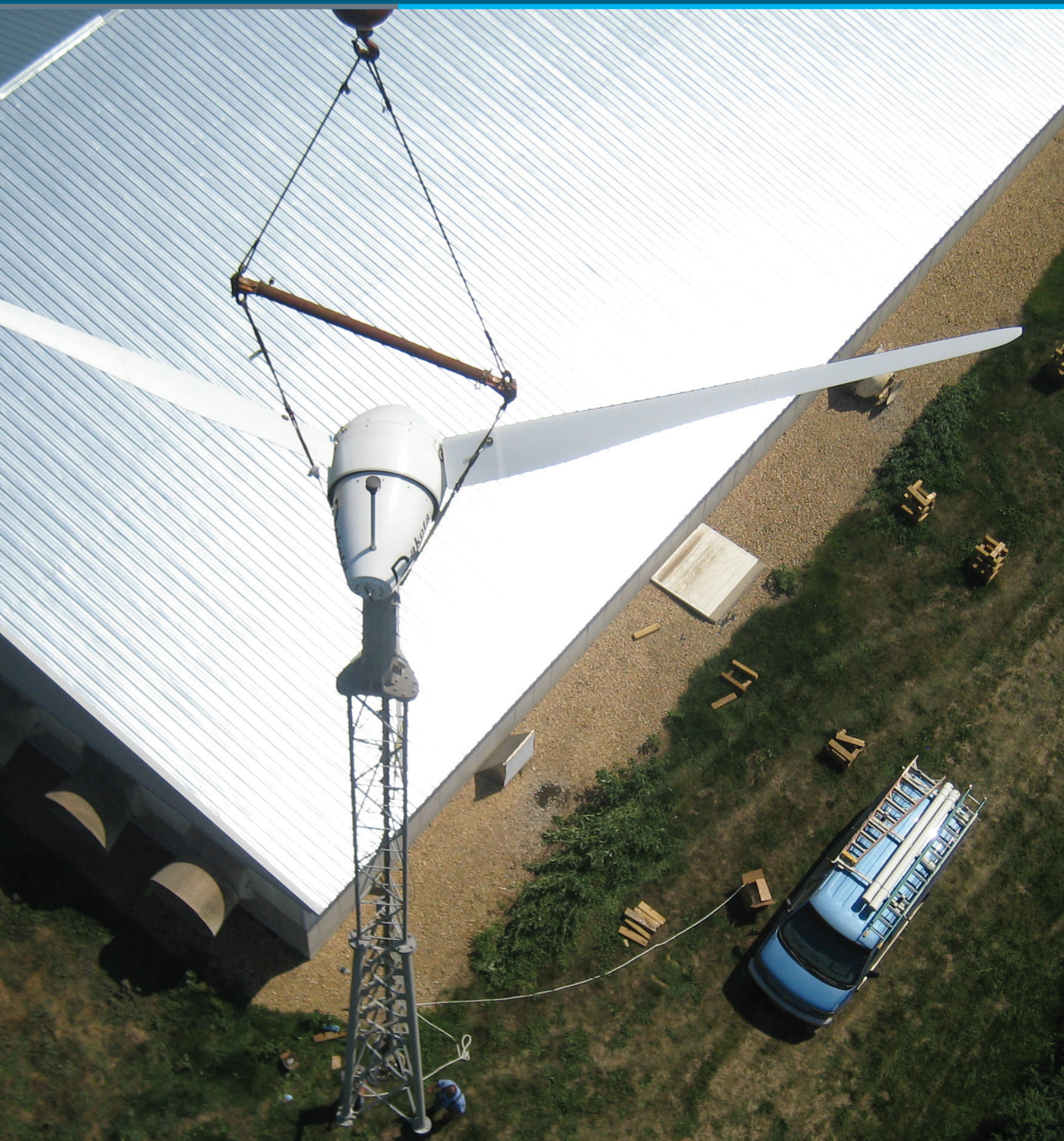




\section{DISCLAIMER}

This report was prepared as an account of work sponsored by an agency of the United States Government. Neither the United States Government nor any agency thereof, nor Battelle Memorial Institute, nor any of their employees, makes any warranty, express or implied, or assumes any legal liability or responsibility for the accuracy, completeness, or usefulness of any information, apparatus, product, or process disclosed, or represents that its use would not infringe privately owned rights. Reference herein to any specific commercial product, process, or service by trade name, trademark, manufacturer, or otherwise does not necessarily constitute or imply its endorsement, recommendation, or favoring by the United States Government or any agency thereof, or Battelle Memorial Institute. The views and opinions of authors expressed herein do not necessarily state or reflect those of the United States Government or any agency thereof.

This report is being disseminated by the U.S. Department of Energy. As such, this document was prepared in compliance with Section 515 of the Treasury and General Government Appropriations Act for Fiscal Year 2001 (Public Law 106-554) and information quality guidelines issued by the U.S. Department of Energy. Though this report does not constitute "influential" information, as that term is defined in the U.S. Department of Energy's Information Quality Guidelines or the Office of Management and Budget's Information Quality Bulletin for Peer Review, the study was reviewed both internally and externally prior to publication. For purposes of external review, the study benefited from the advice and comments from several individuals representing industry trade associations, wind turbine manufacturers, project developers, law firms, and other federal laboratories.

PACIFIC NORTHWEST NATIONAL LABORATORY

operated by

BATTELLE

for the

UNITED STATES DEPARTMENT OF ENERGY

under Contract DE-AC05-76RL01830

Printed in the United States of America

Available to DOE and DOE contractors from the

Office of Scientific and Technical Information,

P.O. Box 62, Oak Ridge, TN 37831-0062;

ph: (865) 576-8401

fax: (865) 576-5728

e-mail: reports@adonis.osti.gov

Available to the public from the National Technical Information

Service

5301 Shawnee Rd., Alexandria, VA 22312

ph: (800) 553-NTIS (6847)

e-mail: orders@ntis.gov http://www.ntis.gov/about/form.aspx

Online ordering: http://www.ntis.gov 


\title{
2015 Distributed Wind Market Report
}

\author{
Authors: \\ Alice C Orrell \\ Nikolas F Foster \\ Contributor: \\ Scott L Morris \\ Juliet S Homer \\ August 2016 \\ Prepared for the \\ U.S. Department of Energy \\ under Contract DE-AC05-76RL01830 \\ Pacific Northwest National Laboratory \\ Richland, Washington 99352
}




\section{EXECUTIVE SUMMARY}

Between 2003 and the end of 2015, over 75,000 wind turbines, totaling $934 \mathrm{MW}$ in cumulative capacity, were deployed in distributed applications across all 50 states, the District of Columbia, Puerto Rico, and the U.S. Virgin Islands. In 2015, 28 states added $28 \mathrm{MW}$ of new distributed wind capacity, representing 1,713 turbine units and $\$ 102$ million in investment. While the number of units installed increased slightly, capacity additions and investments decreased compared to 2014, when 63.6 MW of new distributed wind capacity from nearly 1,700 turbines was added, representing $\$ 170$ million in investment across 24 states.

In 2015, 4.3 MW of small wind (turbines up through $100 \mathrm{~kW}$ ) was deployed in the United States, representing 1,695 units and over \$21 million in investment. This is slightly higher than in 2014 (3.7 MW of small wind, approximately 1,600 units, and \$20 million in investment), but down from 2013 (5.6 MW, approximately 2,700 units, and \$36 million investment). U.S. small wind manufacturers accounted for nearly $100 \%$ of 2015 domestic small wind sales.

A total of 23.7 MW of capacity was installed in 2015 using turbines greater than $100 \mathrm{~kW}$ in distributed applications. Three of the five manufacturers and suppliers of these turbines, representing 9.4 MW and ten turbine units, were not based in the United States. A total of 14.3 MW and eight turbine units were from the two U.S.-based manufacturers or suppliers.

Ohio, Nebraska, and Connecticut led the United States in new distributed wind power capacity additions in 2015 as a result of larger project installations in those states. California, New York, and Minnesota led the nation for small wind capacity deployment in 2015.
U.S. small wind turbine manufacturers continued to focus on international markets as a source of revenue. From 2014 to 2015, exports from U.S.-based small wind turbine manufacturers doubled, from 11.2 MW by seven manufacturers with a value of $\$ 60$ million to $21.5 \mathrm{MW}$ by six manufacturers with a value of $\$ 122$ million.

Based on small wind turbine manufacturers' reports, the overall capacity-weighted average installed cost of 1.6 MW of newly manufactured small wind turbines sold in the United States in 2015 was $\$ 5,760 / \mathrm{kW}$. This is down from $\$ 6,230 / \mathrm{kW}$ in 2014 from $2.8 \mathrm{MW}$ of sales and $\$ 6,940 / \mathrm{kW}$ in 2013 based on 5 MW of sales.

The 2015 estimated capacity-weighted average capacity factor for a small wind sample size of 3.6 MW from 66 projects in 12 states was $32 \%$. In comparison, 120 small wind projects totaling 19.3 MW from 2013 and 2014 in 15 states had a capacity-weighted average capacity factor of $25 \%$. The capacity-weighted average levelized cost of energy, after incentives, for a small wind sample size of 1.24 MW from 50 projects in 2015 is $11 \notin / \mathrm{kWh}$, slightly lower than the $12 \phi / \mathrm{kWh}$ calculated in 2014 for a sample size of $1.45 \mathrm{MW}$ from 73 projects in 2013 and 2014.

A combination of a general downward trend in state and federal incentive funding levels and programs; the relatively low cost of electricity, driven by low natural gas prices; and competition from other technologies, such as solar photovoltaics, are leading to a further market contraction on the supplier side. However, wind lease programs, first adopted by the solar PV industry, are an emerging market driver as more companies adopt this business model. 


\section{EXECUTIVE SUMMARY}

\section{Other highlights of the report include:}

- U.S.-based small wind turbine manufacturers continued to favor U.S. supply chain vendors for most of their wind turbine components. Self-reported domestic content levels for 2015 ranged from $66 \%$ to $100 \%$. U.S. and international small wind manufacturers, operations and maintenance providers, installers, and developers in the distributed wind market interviewed for this report support jobs in 23 states.

- The combined value of federal, state, and utility funding awards given for distributed wind projects in 2015 was $\$ 10.9$ million, excluding the federal investment tax credit. This reflects a significant decrease from 2012, 2013, and 2014, when funding levels were \$100 million, \$15.4 million, and \$20.4 million, respectively. There was an increase in funding from the U.S. Department of Agriculture (USDA) Rural Energy for America Program, which supported 24 wind projects with almost \$1.4 million in grants in 2015 . This reflects a significant increase from 2014 levels, when the USDA provided $\$ 405,442$ in grants for 15 wind projects.

- In 2015, reported U.S. distributed wind projects encompassed 24 different wind turbine models ranging from $160 \mathrm{~W}$ to $2.85 \mathrm{MW}$ from 15 manufacturers and suppliers. In contrast, there were 34 different wind turbine models ranging from $160 \mathrm{~W}$ to $2 \mathrm{MW}$ from 21 manufacturers and suppliers documented in 2014, and 69 different models ranging from $100 \mathrm{~W}$ to $2 \mathrm{MW}$ from 28 manufacturers and suppliers documented in 2013.

- The number of mid-size and large-scale wind turbine manufacturers whose turbines are in distributed wind projects has contracted since 2012. In 2012, 27 manufacturers of mid-size and large-scale turbine models were represented in distributed wind projects. In both 2013 and 2014, there were six manufacturers. And the contraction continued in 2015 with just five manufacturers.

- The number of small wind manufacturers has also contracted. A total of 31 companies reported U.S. sales in 2012 compared to 16 in 2013, 11 in 2014, and 10 in 2015.

- $91 \%$ of turbine units in 2015 distributed wind applications were deployed to power off-grid sites or charge batteries. However, wind turbines connected to the distribution grid, or "grid-tied" applications, accounted for $99 \%$ of the annual distributed wind capacity (in terms of MW).

- Based on surveys of international government and industry publications, total global small wind installed cumulative capacity is estimated to be at least $1.3 \mathrm{GW}$ as of 2015 .

- The average size of wind turbines in distributed applications installed in 2015 was $16 \mathrm{~kW}$, down from $37 \mathrm{~kW}$ in 2014, up from $11 \mathrm{~kW}$ in 2013, and down from $47 \mathrm{~kW}$ in 2012. These jumps in size can be explained by the change in the most commonly used turbines in the given years. In 2012, many mid-size and large-scale turbines were deployed in distributed applications. But in 2013, off-grid wind turbines and smaller units represented a greater portion of projects. In 2014, the number of mid-size and large-scale turbines rebounded, increasing the average wind turbine size used in distributed applications. And in 2015, the number of midsize and large-scale turbine installations declined from 2014 causing the average size to drop again.

- The top five U.S. small wind turbine manufacturers and suppliers, based on 2015 sales in terms of capacity (MWs of domestic sales and exports), were Northern Power Systems of Vermont; Renewtech of Minnesota; Ogin of Massachusetts; Primus Wind Power of Colorado; and Bergey WindPower of Oklahoma.

- Agricultural and residential installations accounted for the majority of 2015 projects ( $46 \%$ and $24 \%$ respectively), but only $13 \%$ of the total distributed wind capacity installed in 2015. Industrial projects, for clients including Ball Corporation, Whirlpool Corporation, Method Manufacturing, and Stafford County Flour Mills, accounted for $37 \%$ of the distributed wind capacity installed in 2015 .

- Building on small wind turbine certification programs initiated in 2012, the certification of small and medium wind turbines continued in 2015. A total of 13 different small turbine models are fully certified to American Wind Energy Association (AWEA) Standard 9.1-2009. Four medium wind turbine models have published power performance and acoustics certifications to International Electrotechnical Commission (IEC) 61400-12-1 (power) and IEC 61400-11 (acoustics). 


\section{ACKNOWLEDGMENTS}

The authors wish to thank the following people for their help in producing this report

Michael Derby, Patrick Gilman, Liz Hartman, and Mark Higgins (U.S. Department of Energy's Wind and Water Power Technologies Office [WWPTO]); Bret Barker, Alex Lemke, and Devan Willemsen (in support of WWPTO); Hannah Hunt (American Wind Energy Association); Jennifer Jenkins (Distributed Wind Energy Association); David Schulz (David Schulz Design Works); Mike Parker (PNNL).

The authors wish to thank the following people for their review and/or contributions to this report

Robert Preus, Ruth Baranowski, Karin Sinclair, Jason Fields (National Renewable Energy Laboratory); Mark Bolinger, Ryan Wiser (Lawrence Berkeley National Laboratory); Brent Summerville (Small Wind Certification Council); Lauren Powell, Jereme Kent (One Energy LLC); Dennis Williams (Williams Power Systems); Justin Baca (Solar Energy Industries Association); Paul Rekow (Iowa small wind expert); Larry Sherwood (Interstate Renewable Energy Council); Hannah Hunt (American Wind Energy Association); James Duffy (Nixon Peabody); Mark Shu (Ogin Energy); Mateo Chaskel (UGE International); Charlie Duo (Asian Development Bank); Hikaru Matsumiya (HikaruWindLab); Terry Spradley (St. John News).

The authors wish to thank the following companies for contributing data, information, and support for this report Advanced Energy Systems, LLC; Aegis Renewable Energy; Bergey Windpower; Black Island Wind Turbines; BTI Energy; Dakota Turbines; Endurance Wind Power; Eocycle Technologies; Ethos Distributed Energy; Gaia-Wind; Ghrepower; Great Rock Windpower; Hire Electric; Kettle View Renewable Energy; Matrix Wind Solutions; Niagara Wind \& Solar; Northern Power Systems; Norvento Enerxia; Ogin; Pika Energy; Primus Wind Power; Renewtech; Skylands Renewable Energy, LLC; Solid Wind Power; Sonkyo Energy; Swet; UGE International; United Wind; Van Wall Energy; Weaver Wind Energy; WES Engineering; Williams Power Systems; Wind Turbine Industries Corporation; Windsine, LLC.

The authors wish to thank representatives from the following utilities and state, federal, and international agencies for contributing data and information for this report

U.S. Treasury; Federal Aviation Administration; Open Energy Information; NREL Wind for Schools; U.S. Department of Agriculture; AEP Southwestern Electric Power Company; Agência Nacional de Energia Elétrica; Alaska Energy Authority; ASSIEME; Australia Clean
Energy Council; Bundesverband WindEnergie; California Energy Commission; Central Lincoln People's Utility District; Chinese Wind Energy Equipment Association; City of San Marcos; Connecticut Clean Energy; Delaware Electric Cooperative; Energinet Denmark; Farmer's Electric Cooperative; Guadalupe Valley Electric Cooperative; Hawaiian Electric Companies; Florida Office of Energy ; Focus on Energy; Holy Cross Energy; Iowa Farmer's Electric Cooperative (Kalona); Iowa Utilities Board; Western Illinois University; Illinois Department of Commerce and Economic Opportunity; Kansas State Energy Office; Kentucky Cabinet for Economic Development, Department of Financial Incentives; Korea Electrotechnology Research Institute; La Plata Electric Association; Massachusetts Clean Energy Center; Minnesota State Energy Office; New Zealand Wind Energy Association; Sustainable Energy Association of New Zealand; Northwest Arctic Borough; Mohave Electric Cooperative; Montana Department of Environmental Quality; Moorhead Public Service Utility; NC GreenPower; New York State Energy Research \& Development; Northern Indiana Public Service Company; NorthWestern Energy; Energy Trust of Oregon; Rhode Island Office of Energy Resources; San Miguel Power Association; Virginia Department of Mines, Minerals, and Energy; Washington D.C. Department of Energy \& Environment; Washington State University Energy Program; United Power Company.

The authors would like to thank representatives from the following utilities and state, federal, and international agencies for their support of this report

U.S. Environmental Protection Agency; U.S. Geological Service; U.S. Energy Information Administration; Arkansas Energy Office; Colorado Energy Office; Georgia Environmental Finance Authority; Hawaii Public Utilities Commission; Idaho Office of Energy Resources; Kansas State University; Kansas Energy Information Network; Kentucky Energy and Environment Cabinet; Korea Institute for Energy Research; Louisiana Department of Natural Resources; Efficiency Maine; Michigan Economic Development Corporation; New Jersey Board of Public Utilities; Ohio Energy Resources Division; Oklahoma Department of Commerce; Pennsylvania Department of Environmental Protection; Reading Municipal Light Department; South Carolina Energy Office; South Dakota Public Utilities Commission; Southeastern Wind Coalition; Sulphur Springs Valley Electric Cooperative, Inc.; TVA Green Power Providers; Texas State Energy Conservation Office; Vermont Clean Energy Development Fund; Virginia Department of Mines, Minerals and Energy; West Virginia Energy Office; Wyoming State Energy Office. 


\section{ACRONYMS AND ABBREVIATIONS}

\begin{tabular}{|c|c|}
\hline AWEA & American Wind Energy Association \\
\hline BEWT & built-environment wind turbine \\
\hline C\&l & commercial and industrial \\
\hline CAGR & compound annual growth rate \\
\hline CIP & Competitiveness Improvement Project \\
\hline DECC & Department of Energy and Climate Change \\
\hline DOE & U.S. Department of Energy \\
\hline DWEA & Distributed Wind Energy Association \\
\hline EC & European Commission \\
\hline EIA & Energy Information Administration \\
\hline FIT & feed-in-tariff \\
\hline GE & General Electric \\
\hline GW & gigawatt \\
\hline IEC & International Electrotechnical Commission \\
\hline IRS & Internal Revenue Service \\
\hline ITC & investment tax credit \\
\hline $\mathrm{kV}$ & kilovolt \\
\hline $\mathrm{kW}$ & kilowatt \\
\hline $\mathrm{kWh}$ & kilowatt-hour \\
\hline LCOE & levelized cost of energy \\
\hline $\mathrm{m}$ & meter \\
\hline$m^{2}$ & square meter \\
\hline MACRS & Modified Accelerated Cost-Recovery System \\
\hline MW & megawatt \\
\hline MWh & megawatt-hour \\
\hline NREL & National Renewable Energy Laboratory \\
\hline NYSERDA & New York State Energy Research and Development Authority \\
\hline O\&M & operations and maintenance \\
\hline OEM & original equipment manufacturer \\
\hline PBI & performance-based incentive \\
\hline PNNL & Pacific Northwest National Laboratory \\
\hline PPA & power purchase agreement \\
\hline PTC & production tax credit \\
\hline PV & photovoltaic \\
\hline REAP & Rural Energy for America Program \\
\hline SMART & Sustainable Manufacturing, Advanced Research \& Technology \\
\hline SWCC & Small Wind Certification Council \\
\hline USDA & U.S. Department of Agriculture \\
\hline USVI & U.S. Virgin Islands \\
\hline VAWT & vertical-axis wind turbine \\
\hline W & watt \\
\hline
\end{tabular}




\section{CONTENTS}

Executive Summary

Acknowledgments

Acronyms and Abbreviations

i

iii

iv

1.0 Introduction

2.0 U.S. Distributed Wind Deployment

3.0 Domestic Sales, Imports, Exports, and the Global Market

4.0 Policy and Market Drivers

5.0 Installed, O\&M, and Soft Costs 25

6.0 Performance 28

7.0 Levelized Cost of Energy 31

8.0 Distributed Wind Markets 34

9.0 Manufacturing, Domestic Supply Chain, and Jobs 39

10.0 Outlook 40

$\begin{array}{lll}11.0 & \text { References } & 41\end{array}$

Appendix A: Wind Turbine Manufacturers and Suppliers 44

Appendix B: Methodology $\quad 44$

\section{TABLES}

1 U.S. Small Wind and the Global Market 10

2 USDA REAP Wind Awards, 2012-2015 16

3 Solar PV and Small Wind Incentive Programs Comparison 19

4 Solar PV and Small Wind Rebate Program 2015 Funding Comparison 20

$5 \quad$ Certified Small and Medium Wind Turbines (IREC 2016) 23

6 Global Small Wind Projections 40 


\section{FIGURES}

1 U.S. Distributed Wind Capacity

2015 U.S. Distributed Wind Capacity Additions by State 3

3 2003-2015 Cumulative U.S. Distributed Wind Capacity by State 4

4 Top States for Distributed Wind Capacity, 2003-2015 5

5 Top States for Small Wind Capacity, 2003-2015 6

$6 \quad$ U.S. Small Wind Turbine Sales and Exports, 2003-2015 8

$7 \quad$ The Shift in U.S. Small Wind Exports and Domestic Sales 9

$8 \quad$ U.S. Small Wind Exports Map 9

92015 U.S. Distributed Wind Incentive Awards 13

10 U.S. Small Wind Turbine Sales and Federal Policies, 2003-2015 14

112014 and 2015 USDA REAP Awards 17

12 Small Wind and Residential Solar PV Installed Costs 22

13 Nominal Newly Manufactured U.S. Installed Small Wind Turbine Costs Reported by Manufacturers 25

142015 Small Wind Project Costs 26

15 Estimated Capacity Factors for Selected 2015 Small Wind Projects 29

162014 Reported Capacity Factors for Selected Distributed Wind Projects using Turbines
Greater than 100 kW

17 Levelized Costs of Energy (after Incentives) for Selected 2015 Small Wind Projects 31

18 Levelized Costs of Energy (after Section 1603 Funding) for Selected Distributed Wind Projects Using Turbines Greater than 100 kW

19 Levelized Costs of Energy and Capacity Factors for Selected Small Wind Projects 33

20 Levelized Costs of Energy and Capacity Factors for Selected Distributed Wind Projects

212015 Distributed Wind Project Types by Capacity and by Project 35

22 U.S. Small Wind Turbine Sales by Turbine Size 36

23 U.S. Distributed Wind Capacity by Type and Average Turbine Size 37

24 Cumulative Wind Farm and Distributed Wind Turbine Units, 2003-2015 38

252015 Wind Farm and Distributed Wind Turbine Units 38 


\subsection{Introduction}

The U.S. Department of Energy's (DOE's) annual Distributed Wind Market Report provides stakeholders with statistics and analysis of the market along with insights into its trends and characteristics. By providing a comprehensive overview of the distributed wind market, this report can help plan and guide future investments and decisions by industry, utilities, federal and state agencies, and other interested parties.

Distributed wind is defined by the wind project's location relative to end-use and power distribution infrastructure, rather than turbine or project size. Distributed wind includes the following:

- wind energy systems, either off-grid' or grid-connected, at homes, farms and ranches, businesses, public and industrial facilities, or other sites to offset all or a portion of the local energy consumption at or near those locations, or

- systems connected directly to the local grid $^{2}$ to support grid operations and local loads.

Distributed wind is differentiated from wholesale power generated at large wind farms and sent via transmission lines to substations for distribution to loads and distant end-users.

Grid-connected distributed wind systems can be located on the distribution grid or on the customer side of the meter, either physically or virtually. Virtual net metering is a billing arrangement that allows multiple energy customers to receive net metering credit from a shared on-site, or remote renewable energy system within the customers' utility service area, as if it was located behind the customer's own meter (Freeing the Grid 2015).

Because the definition of distributed wind depends on where the project is located and how the power is used, the distributed wind market includes wind turbines and projects of many sizes. For example, distributed wind systems can range from a less than $1 \mathrm{~kW}^{3}$ off-grid wind turbine at a remote cabin or well head, to a $10 \mathrm{~kW}$ wind turbine at a home or farm, to several multi-megawatt wind turbines at a university campus, manufacturing facility, or other large facility.

\subsection{Purpose of Report}

The annual Distributed Wind Market Report supports DOE's effort to increase the deployment of distributed wind across the United States, raise the quality of installed distributed wind products, and grow the nation's domestic energy industry. The report provides key information on current market conditions and regulatory environments that will help stakeholders increase the cost competitiveness of distributed wind systems and build better turbines and components, leading to improved grid integration and increased customer and utility confidence in distributed wind systems.

Distributed energy can offer solutions to many of the nation's leading energy supply issues by providing resilience against blackouts and brownouts, mitigating energy security concerns and power-quality issues, meeting tighter emissions standards, reducing transmission bottlenecks, and allowing greater control over energy costs.

Distributed wind also supports the nation's manufacturing economy as U.S.-based small wind turbine manufacturers rely on a largely U.S. supply chain for their wind turbine components. These manufacturers supply the majority of the small wind turbines deployed domestically and are leading exporters to an expanding global market.

\subsection{Wind Turbine Size Classification}

The distributed wind market includes wind turbines and projects of many sizes. When appropriate, this report breaks the market into the following three turbine size segments:

- wind turbines up through $100 \mathrm{~kW}$ (in nominal capacity) referred to in this report as "small wind,"

- mid-size wind turbines $101 \mathrm{~kW}$ to $1 \mathrm{MW}$, and

- large-scale wind turbines greater than $1 \mathrm{MW}$.

The U.S. Internal Revenue Service (IRS) defines small wind as up through $100 \mathrm{~kW}$ for the purpose of federal investment tax credit (ITC) eligibility (see Section 4.1.2). For certification purposes, international and domestic standards define small wind turbines as having rotor swept areas up to $200 \mathrm{~m}^{2}$ (approximately 50 to $65 \mathrm{~kW}$ ) and medium wind turbines as having rotor swept areas greater than $200 \mathrm{~m}^{2}$ (see Table 5). DOE's annual Wind Technologies Market Report (Wiser and Bolinger 2015) concentrates only on U.S. wind projects using turbines greater than $100 \mathrm{~kW}$. This Distributed Wind Market Report specifically analyzes distributed wind projects of all sizes and details the annual U.S. small wind market.

\footnotetext{
${ }^{1}$ Off-grid wind turbine systems directly serve on-site loads and typically include battery backup or other energy storage as they are not connected to the local distribution grid.

${ }^{2}$ The local grid is defined as distribution lines with interconnected electric load(s), typically at a voltage of $34.5 \mathrm{kV}$ or below.

${ }^{3} 1 \mathrm{GW}=1,000 \mathrm{MW} ; 1 \mathrm{MW}=1,000 \mathrm{~kW} ; 1 \mathrm{~kW}=1,000 \mathrm{~W}$.
} 


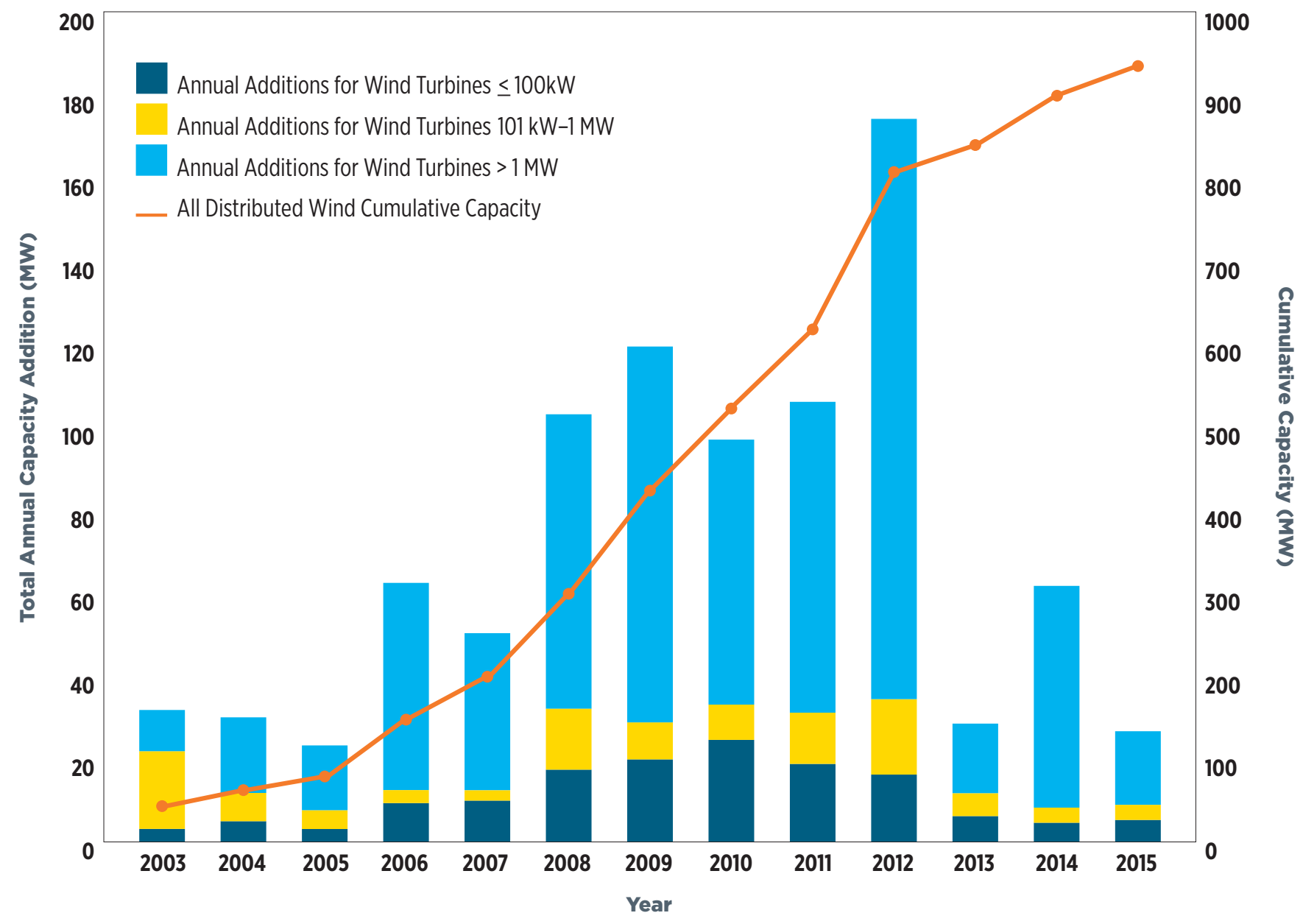

Figure 1. U.S. Distributed Wind Capacity

\subsection{U.S. Distributed Wind Deployment}

Between 2003 and the end of 2015, over 75,000 wind turbines were deployed in distributed applications across all 50 states, Puerto Rico, and the U.S. Virgin Islands (USVI), totaling $934 \mathrm{MW}$ in cumulative capacity (Figure 1). ${ }^{4}$ In 2015, 28 states added $28 \mathrm{MW}$ of new distributed wind capacity, representing 1,713 units and $\$ 102$ million in investment.

In 2015, 4.3 MW of small wind (turbines up through $100 \mathrm{~kW}$ ) was deployed in the United States, representing 1,695 units and over \$21 million in investment. This is slightly higher than 2014, during which the U.S. small wind turbine market deployed 3.7 MW of small wind representing about 1,600 units and $\$ 20$ million in investment, but down from the $5.6 \mathrm{MW}$ and roughly 2,700 units that resulted in the \$36 million investment recorded for 2013.

Of the 8,598 MW of wind project installations in 2015 using turbines greater than $100 \mathrm{~kW}$ (AWEA 2016), $23.7 \mathrm{MW}$ were considered to be installed in distributed applications representing \$81 million in investment. In 2014, this figure was $60 \mathrm{MW}$ out of the overall 4,584 MW of wind capacity installed; in 2013, it was 24.8 MW out of 1,087 MW.

\subsection{Top States for Distributed Wind: Annual and Cumulative Capacity}

New distributed wind projects were documented in 28 states in 2015 (Figure 2) and have been documented in all 50 states, the District of Columbia, Puerto Rico, and the USVI since 2003 (Figure 3).

Ohio, Nebraska, and Connecticut led the United States in new distributed wind power capacity additions in 2015 as a result of larger project installations in those states. California, New York, and Minnesota led the nation for small wind capacity deployment in 2015. All of the small wind in California was deployed in the southern part of the state. ${ }^{5}$ In New York and Minnesota, the majority of the small wind turbine installations reported were at farms and agricultural operations.

\footnotetext{
${ }^{4}$ The data presented in the figures are provided in an accompanying data file available for download at http://energy.gov/eere/wind/downloads/2015-distributed-wind-market-report.

${ }^{5}$ This report tracks small wind turbine sales as part of distributed wind, but the small wind in California may have been installed in projects that do not strictly meet the distributed wind definition.
} 


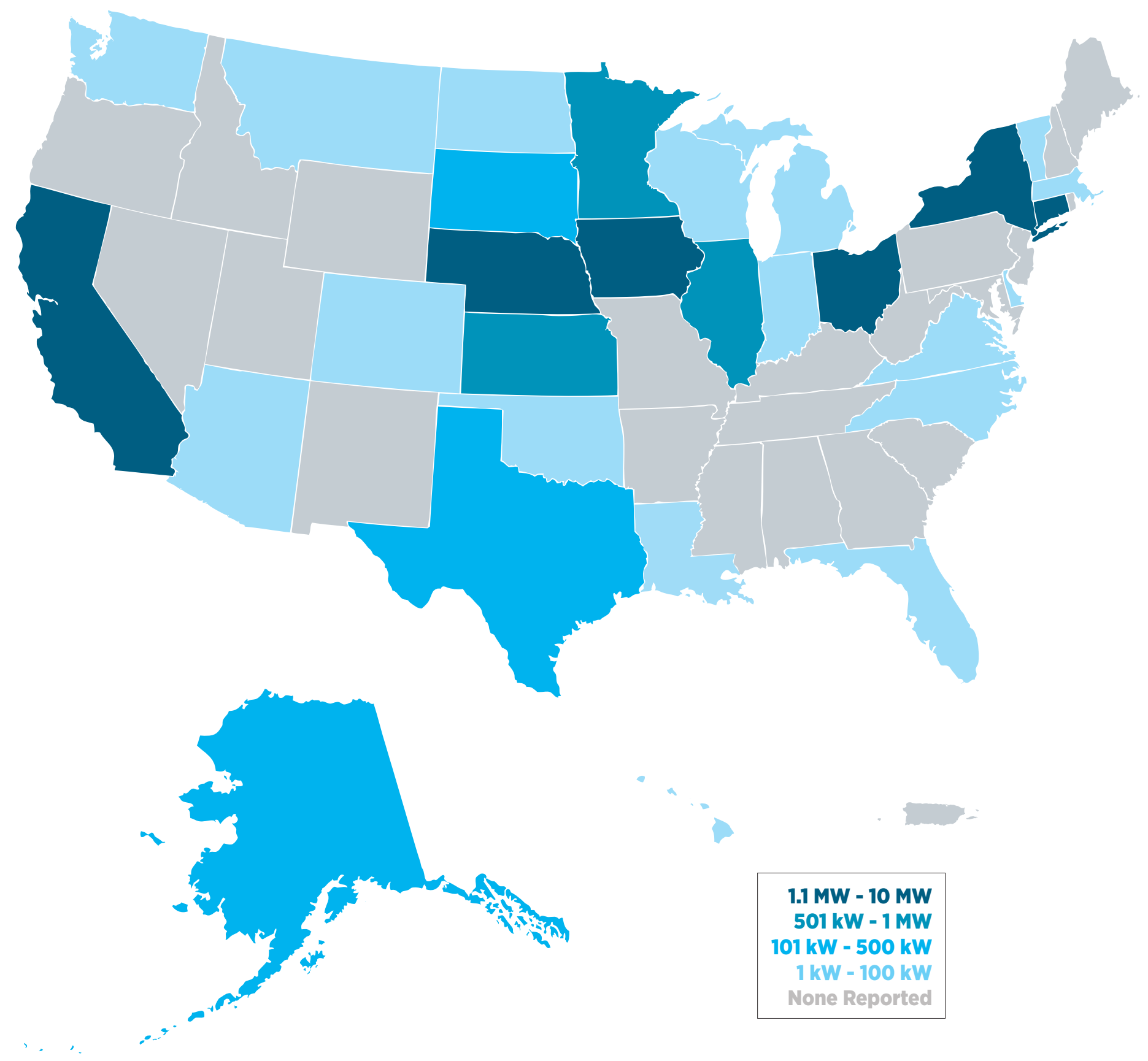

Figure 2. 2015 U.S. Distributed Wind Capacity Additions by State 
Texas, Minnesota, and Iowa retained their top positions for the states with the most distributed wind capacity deployed since 2003 (Figure 3 and Figure 4). With a 6.8 MW project in 2015, Nebraska joined the ranks of states with over $10 \mathrm{MW}$ of distributed wind installed. Iowa, Nevada, and California maintained their leading positions with respect to cumulative installed small wind capacity (Figure 5). Even with no reported small wind installations in 2015, Iowa is still at the top given its significant cumulative lead due to the state's early adoption of and support for wind power.

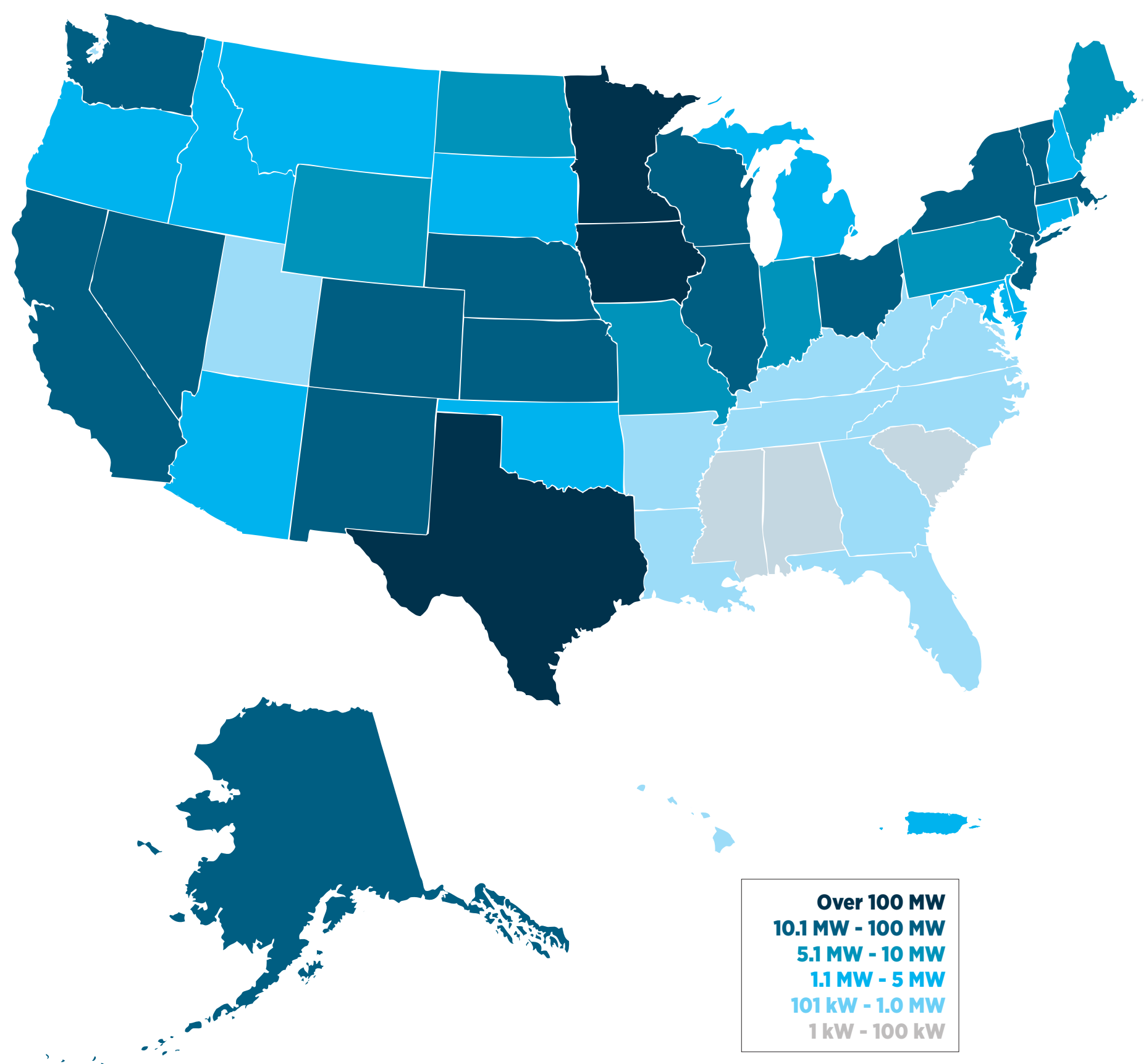

Figure 3. 2003-2015 Cumulative U.S. Distributed Wind Capacity by State 


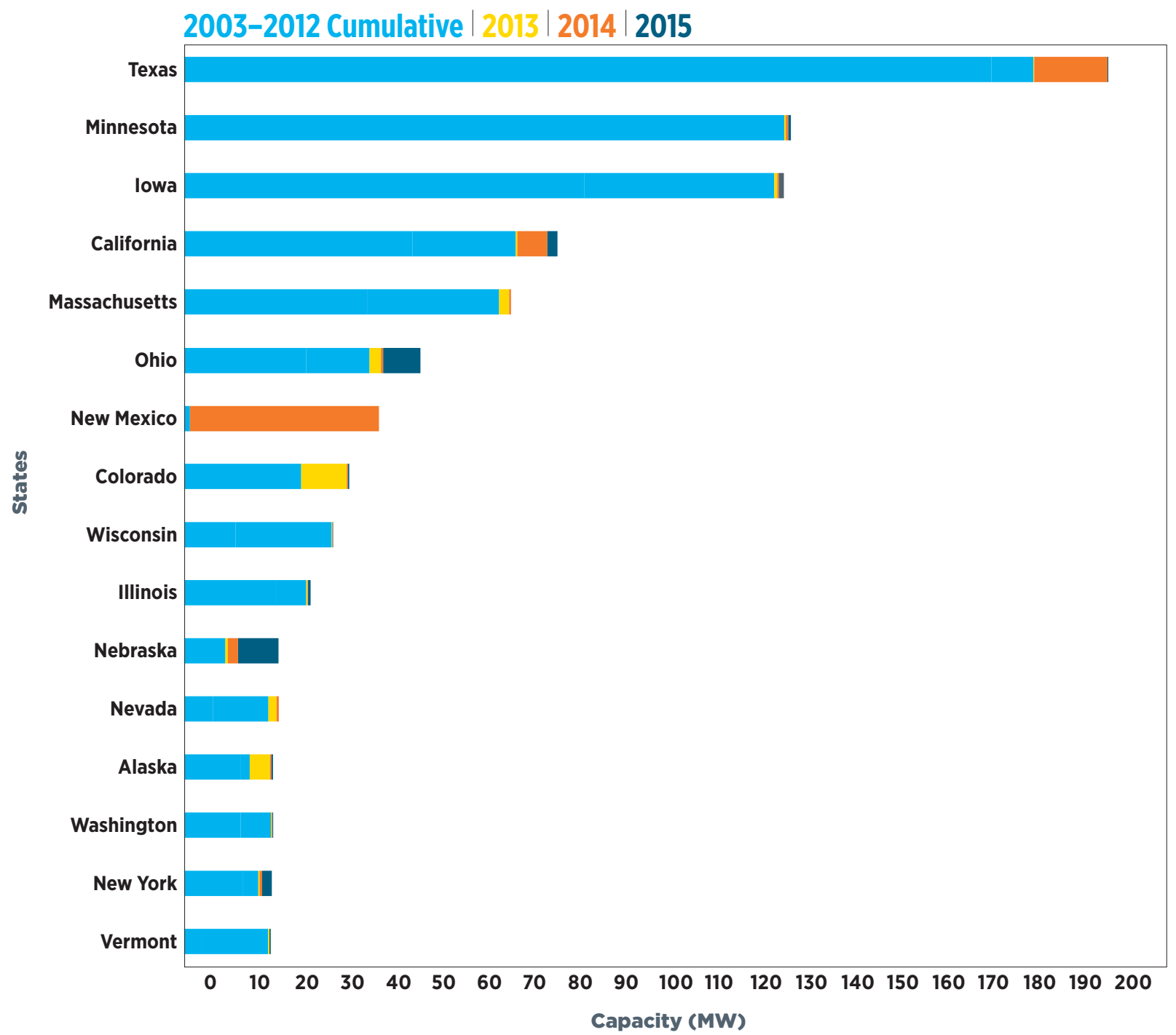

Figure 4. Top States for Distributed Wind Capacity, 2003-2015 


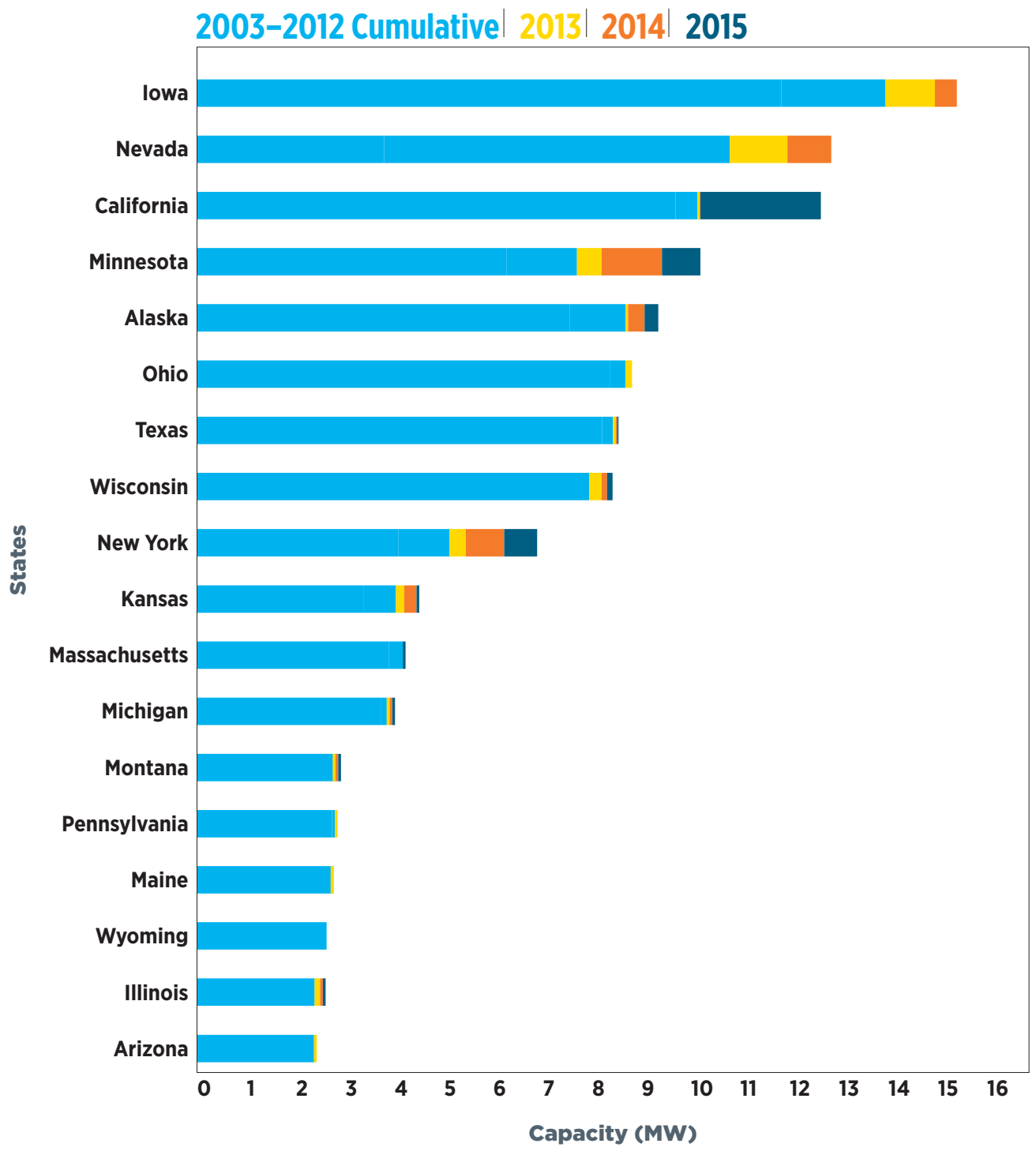

Figure 5. Top States for Small Wind Capacity, 2003-2015 


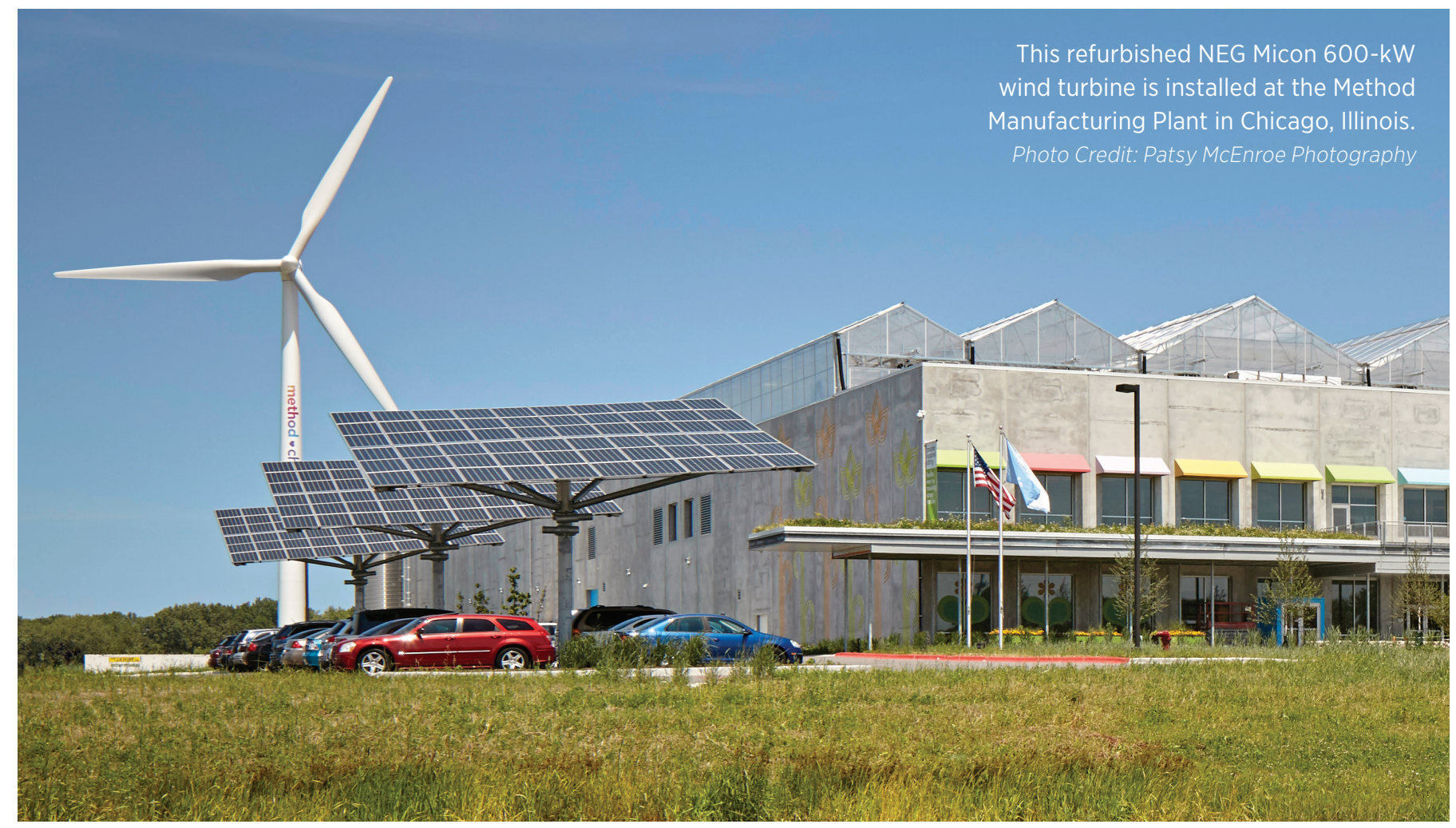

\subsection{Domestic Sales, Imports, Exports, and the Global Market}

The ten small wind turbine manufacturers with a 2015 U.S. sales presence accounted for in this report consist of eight domestic manufacturers headquartered in eight states (Colorado, Maine, Massachusetts, Minnesota, New York, North Dakota, Oklahoma, and Vermont) and two importers.

Similar to last year, there were few responses to the Pacific Northwest National Laboratory's (PNNL's) data request from non-U.S.-based small wind turbine manufacturers. Of the eight foreign manufacturers who replied, only two reported sales in the United States in 2015, Gaia-Wind (United Kingdom) and Sonkyo Energy (Spain), although sales from foreign manufacturers from previous years may have been installed in the United States in 2015.

The top five U.S. small wind turbine manufacturers, based on 2015 sales in terms of capacity (MWs of domestic sales and exports), were Northern Power Systems of Vermont; Renewtech of Minnesota; Ogin of Massachusetts; Primus Wind Power of Colorado; and Bergey WindPower of Oklahoma. Six U.S. small wind turbine manufacturers had exports to outside of the United States. All U.S. small wind manufacturers with sales included in this report are listed in Appendix A.

Five manufacturers and suppliers ${ }^{6}$ of turbines greater than $100 \mathrm{~kW}$ with a 2015 U.S. sales presence are accounted for in this report: one U.S.-based ${ }^{7}$ manufacturer (GE Renewable Energy), three importers (Gamesa, Goldwind, and Vergnet), and one U.S.-based supplier of a refurbished turbine (RockWind Venture Partners).

\subsection{Domestic Sales}

The 4.3 MW of small wind sales recorded in 2015 represent 1,695 units and over $\$ 21$ million in investment. This is slightly higher than in 2014 (3.7 MW deployed, about 1,600 units, and an approximately $\$ 20$ million investment), but down from 2013 (5.6 MW deployed, about 2,700 units, and an approximately $\$ 36$ million investment). No refurbished small wind turbine sales were reported for 2015. U.S. small wind manufacturers accounted for nearly $100 \%$ of the 2015 U.S. domestic small wind sales, as shown in Figure 6. Figure 6 shows annual domestic, export, refurbished, and import sales of small wind turbines.

\subsection{MW of capacity was installed in 2015 using turbines} greater than $100 \mathrm{~kW}$. While U.S. manufacturers dominate the small wind domestic sales, the mid-size and large-scale turbine markets rely more on imports. Three of the five manufacturers or suppliers of turbines greater than $100 \mathrm{~kW}$ with installations in the United States in 2015 were non-U.S.-based representing 9.4 MW and ten turbine units. 14.3 MW and eight turbine units were from U.S.-based manufacturers or suppliers.

\footnotetext{
${ }^{6}$ In relation to manufacturers, suppliers refer to remanufacturers of domestic and imported turbines.

${ }^{7}$ U.S.-based means the manufacturer or supplier is headquartered in the United States.
} 


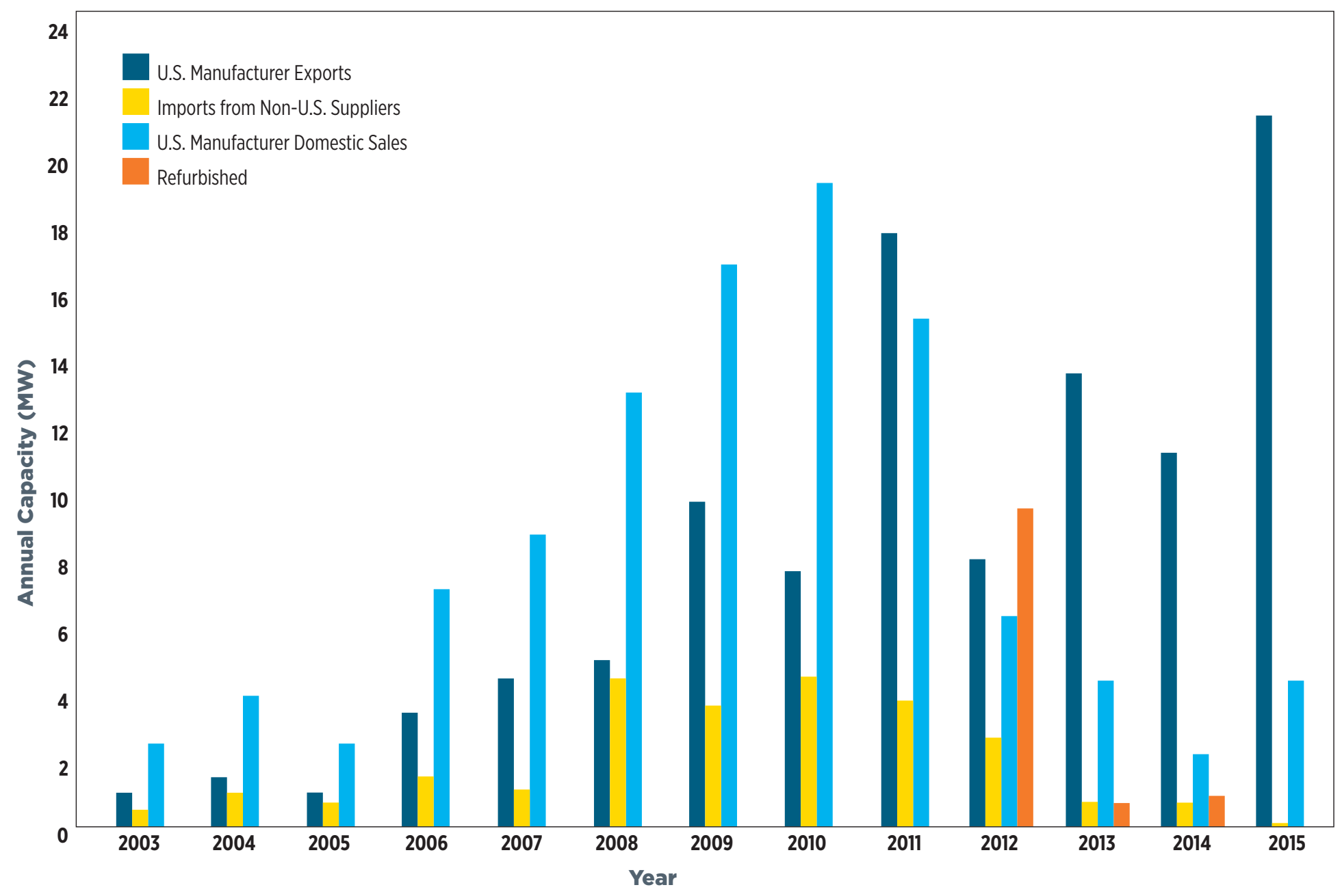

Figure 6. U.S. Small Wind Turbine Sales and Exports, 2003-2015

\subsection{Exports}

U.S. small wind turbine manufacturers continued to focus on international markets as a source of revenue. At 21.5 MW with an estimated value of $\$ 122$ million from six manufacturers, exports from U.S.-based small wind turbine manufacturers in 2015 doubled from 2014 (11.2 MW from seven manufacturers with a value of $\$ 60$ million). As shown in Figure 7, exports represent an increasing amount of U.S. small wind turbine manufacturers' sales capacity. In 2010, exports accounted for

$29 \%$ of U.S. small wind manufacturers sales. In 2015, this increased to $83 \%$. This shift can be explained by changes in domestic support for small wind, such as the ending of the U.S. Department of Treasury's 1603 program grants, and competition from solar photovoltaics (PV). In contrast, other countries, such as the UK and Italy, have seen high sales over the past five years as a result of feed-in tariff (FIT) and other policies that support small wind.

The top reported export markets in terms of capacity were Italy, the United Kingdom, and Japan. Figure 8 shows the primary reported countries that received U.S. small wind exports. 


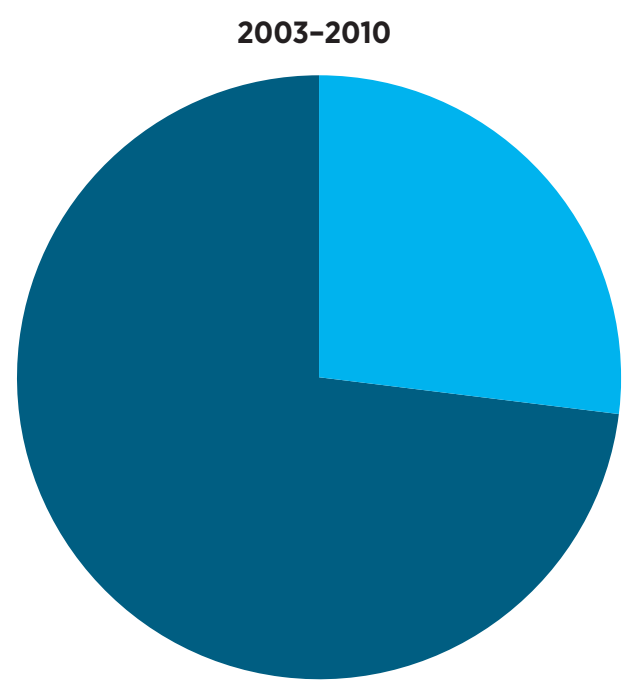

33.7

91.0
Exports (MW)

Domestic Sales (MW)
2011-2015

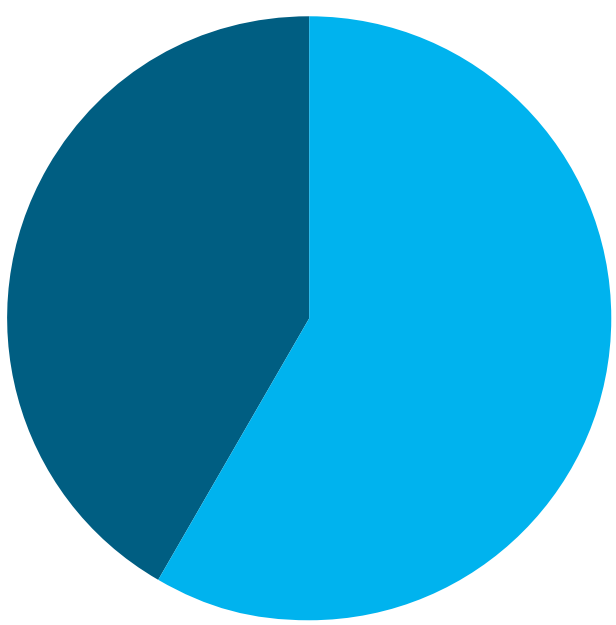

72

51.0

Figure 7. The Shift in U.S. Small Wind Exports and Domestic Sales

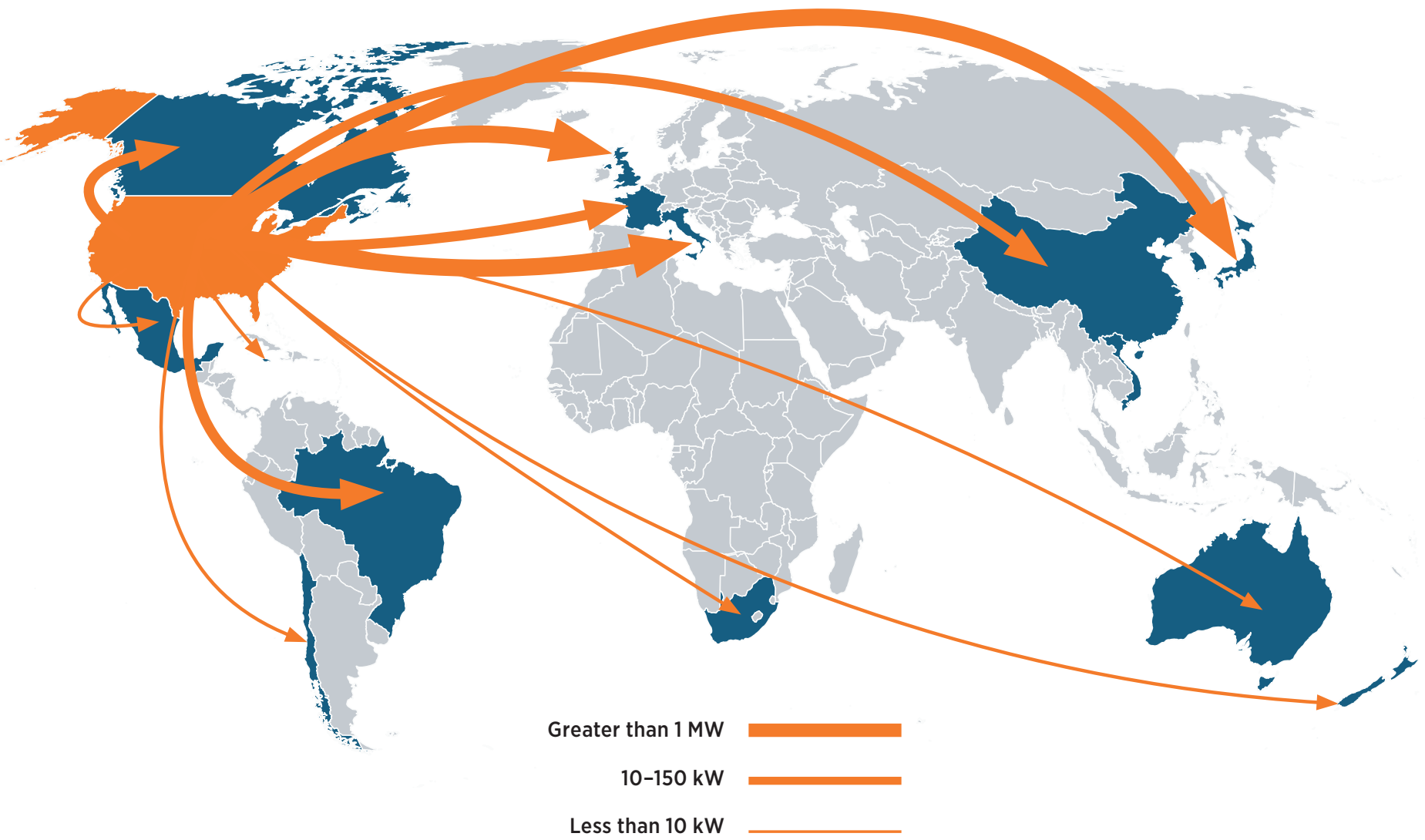

Figure 8. U.S. Small Wind Exports Map 
There are multiple U.S. federal agencies that provide services to help U.S. exporters compete in the global market. Export. gov leverages resources from across the U.S. government to assist American businesses in planning their international sales strategies. The Renewable Energy \& Energy Efficiency Exporter Portal (export.gov/REEE) specifically supports green energy exports and is managed by the U.S. International Trade Administration in collaboration with other U.S. government agencies.

\subsection{Imports}

Reported sales in the United States from foreign small wind turbine manufacturers dropped again in 2015 with only two manufacturers reporting sales. While most of the non-U.S.based manufacturers who responded to the data request for this report did not have sales in the United States, they did have sales in other markets, mostly in the United Kingdom and Italy.

The mid-size and large-scale markets continued to be supplied by a mix of U.S.-based and foreign manufacturers. In 2015, 40\% of the installed distributed wind capacity using turbines greater than $100 \mathrm{~kW}$ was supplied by non-U.S.-based manufacturers Gamesa, Goldwind, and Vergnet. In 2014, this figure was 85\% from Gamesa, PowerWind, RRB Energy, Siemens, and Vestas. GE Renewable Energy was the only U.S.-based manufacturer to supply the balance of installations in both 2014 and 2015 .
The mix of manufacturers and suppliers of mid-size and large-scale turbines in the past few years, and the few number of these players overall, suggests no one of them has a strong position in the U.S. distributed wind market.

\subsection{Small Wind Global Market}

The market for small wind turbines continues to grow globally, albeit at varying rates. The two leading countries for installed small wind cumulative capacity - China and the United States - registered declining capacity installations between 2013 and 2014, while the United Kingdom and Italy - the two leading European countries for small wind capacity - doubled their capacity installed in the same timeframe. Based on surveys of international government and industry publications, PNNL calculated the cumulative capacity installed in 11 surveyed countries at $1.2 \mathrm{GW}$ as shown in Table 1 . The World Wind Energy Association has estimated that China, the United States, and the United Kingdom represent between $80 \%$ and $90 \%$ of the global small wind market (Gsänger and Pitteloud 2014; Gsänger and Pitteloud 2016). Based on this estimate and PNNL's surveys, total global installed cumulative capacity is estimated to be at least $1.3 \mathrm{GW}$ as of 2015 .

Table 1. U.S. Small Wind and the Global Market ${ }^{8}$

$\begin{array}{lccccc} & \begin{array}{c}2013(M W) \\ \text { Installations }\end{array} & \begin{array}{c}2014(\mathrm{MW}) \\ \text { Installations }\end{array} & \begin{array}{c}2015(\mathrm{MW}) \\ \text { Installations }\end{array} & \begin{array}{c}\text { Cumulative (MW) } \\ \text { Installations }\end{array} & \begin{array}{c}\text { Cumulative } \\ \text { Year Range }\end{array} \\ \begin{array}{lcccc}\text { China } \\ \text { Japan }\end{array} & 75 & 72.6 & * & 790.7^{\mathrm{a}} & 2002-2014 \\ \text { South Korea } & * & * & 0.364 & 4.6^{\mathrm{b}} & \text { as of } 2015 \\ \text { UK } & 14.7 & 28.5 & 11.7 & 127.4^{\mathrm{d}} & \text { as of } 2015 \\ \text { Denmark } & 1.216 & 1.441 & 5.025 & 17.6^{\mathrm{e}} & 1978-2015 \\ \text { Germany } & * & 0.264 & 0.298 & 26.3^{\mathrm{f}} & 2010-2015 \\ \text { Italy } & 7.003 & 15.773 & 10.809 & 54.1^{\mathrm{a}} & 2012-2015 \\ \text { United States } & 5.6 & 3.7 & 4.3 & 144 & 2003-2015 \\ \text { Brazil } & 0.029 & 0.023 & 0.11 & 0.2^{\mathrm{h}} & 2013-2015 \\ \text { Australia } & * & * & 0.037 & 1.4^{\mathrm{i}} & 2001-2015 \\ \text { New Zealand } & * & * & * & 0.2^{\mathrm{j}} & \text { as of } 2015 \\ \text { Global } & 103.52 & 122.28 & 32.97 & 1,171 & \end{array}$

\footnotetext{
* Not Available

a China Wind Energy Equipment Association

b Japan Small Wind Turbines Association

c Korea Wind Energy Industry Association; Korea Energy Agency

${ }^{d}$ www.gov.uk, Monthly MCS and ROOFIT degression statistics

e www.energinet.dk
}

\author{
f Bundesnetzagentur; Bundesverband Kleinwindkraftanlagen; \\ 0-50 kW capacity \\ g www.assieme.eu; 0-200kW capacity \\ ${ }^{\text {h }}$ www.aneel.gov.br \\ ' www.cleanenergyregulator.gov.au \\ i Sustainable Electricity Association of New Zealand
}

\footnotetext{
${ }^{8}$ Unknown capacity values are denoted as asterisks.
} 


\subsubsection{Japan}

Since the establishment of the FIT in Japan in the wake of the Fukushima Daiichi nuclear disaster, small wind installations are still gaining traction. Hampered by interconnection restrictions by utilities, as well as the Japanese government's modest goal of wind power contributing just $1.7 \%$ of the country's electricity mix by 2030 , the market for small wind in Japan added $364 \mathrm{~kW}$ of new capacity in 2015 (HikaruWindLab 2016; METI 2015a). The complex process results in a significant lag between approved projects and actual installations. As of November 2015, there were 312 projects representing close to $4.6 \mathrm{MW}$ of capacity approved for the FIT, but only 39 of those projects were installed in 2015. This modest growth comes in spite of the fact that the FIT value is generous. In 2015, wind turbines sized up to $20 \mathrm{~kW}$ received 55 Yen (\$0.51) per kWh and turbines sized $20 \mathrm{~kW}$ and greater received 22 Yen (\$0.21) per kWh (METI 2015b).

\subsubsection{China}

With nearly $800 \mathrm{MW}$ of cumulative capacity installed, China remains the largest market for small wind turbines. Yet, since the $100 \mathrm{MW}$-plus annual additions between 2009 and 2011, the market has been steadily declining. In 2014, $72.6 \mathrm{MW}$ of capacity was installed, reflecting the smallest annual addition since 2007. This decline is also reflected in the shrinking number of Chinese manufacturers, which once numbered over 100 but in 2014 stood at 28-also the smallest number since 2007. The market for Chinese small wind turbines might be contracting due to the general slower performance of the Chinese economy, which in 2015 grew at the slowest rate since 1990 (Magnier 2016). Chinese manufacturers are also seeking greater opportunities in the global market. In 2014, small wind manufacturers reported 19,000 units representing 29.2 MW of capacity exported to 113 countries (CWEEA 2016). The FIT in China was slightly reduced in 2016. For onshore wind power, 2016 tariffs stood between 0.49 and 0.61 Chinese Yuan (\$0.08-\$0.09) per kWh, depending on the wind resource of the area in which they are located (Stock 2016).

\subsubsection{United Kingdom}

In 2015, close to $12 \mathrm{MW}$ of small wind capacity was added in the United Kingdom, representing a significant decrease from the 28.5 MW of small wind capacity deployed in 2014. The FIT underwent sweeping changes in late 2015 and early 2016. In October 2015, the government announced significant changes to the FIT regime, including a deployment cap, as well as a decrease in the incentive value for turbines sized up through $100 \mathrm{~kW}$ from 13.73 pence $(\$ 0.20)$ to 8.61 pence $(\$ 0.12)$ per $\mathrm{kWh}$ and the complete removal of incentives for turbines sized 1.5 MW and greater (DECC 2015a). After the announcement of the tariffs, the UK government received close to 55,000 public comments protesting the decision (DECC 2015b).

As a result of the comments, the government reconsidered the program. After a complete pause to the scheme between January 15 and February 7, 2016, the FIT for wind was reintroduced at 8.64 pence $(\$ 0.12)$ per $\mathrm{kWh}$ for turbines sized up through $100 \mathrm{~kW}, 5.46$ pence $(\$ 0.08)$ per $\mathrm{kWh}$ for turbines sized between $101 \mathrm{~kW}$ and $1.5 \mathrm{MW}$, and 0.86 pence (\$0.01) per $\mathrm{kWh}$ for turbines greater than 1.5 MW (OFGEM 2016). In addition to the changes to the incentive structure, deployment caps were lowered, allowing for only $300 \mathrm{~kW}$ of capacity additions per quarter for projects using turbines sized 50 to $100 \mathrm{~kW}$ (DECC 2015b). The inconsistent position on the FIT and the significantly reduced deployment caps and funding levels might be reflected in lower installations in 2016 and future years.

\subsubsection{Italy}

Italy supports renewable energy via several price and tax regulations mechanisms, including FIT and premium tariffs, tendering schemes, and regional policy measures (Eurobserver 2015). Driven by the renewable energy targets of the country's National Renewable Energy Action Plan, Italy already met the 2020 goal of $26 \%$ of renewable generation in the electricity sector in 2012 (EC 2013). By 2014 , the share of renewable energy in the electricity sector stood close to $39 \%$ (Terna 2014). In 2015, Italy was again a top destination for U.S. exports of small wind turbines and reported total installations of $10.8 \mathrm{MW}$ of small wind capacity, reflecting a decline of $32 \%$ compared to 2014 installations (ASSIEME 2014, 2016). 
This Primus wind turbine powers an off-grid remote monitoring system.

Photo credit: Primus Wind Power

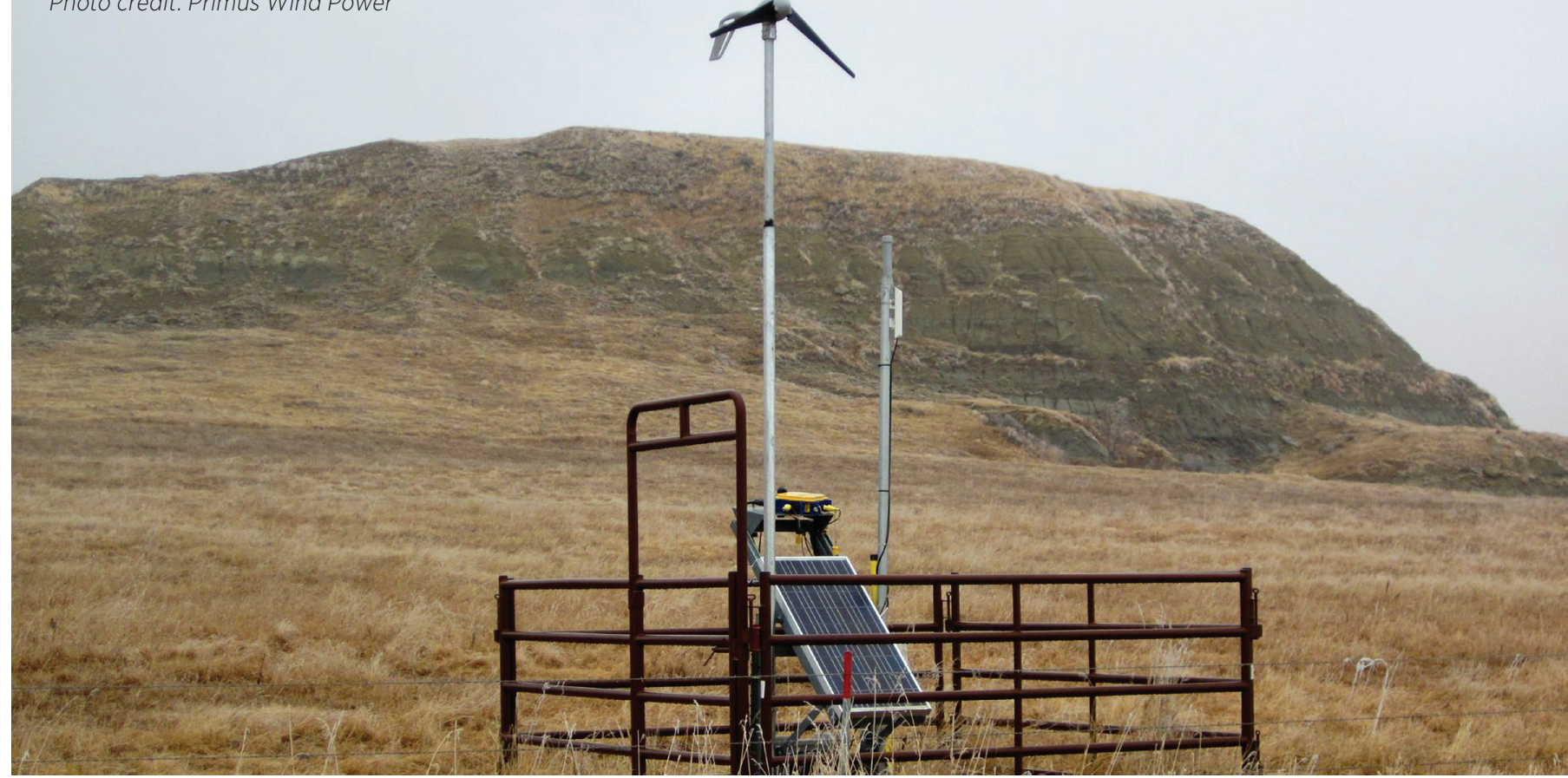

\subsection{Policy and Market Drivers}

Policy decisions and market conditions directly influence manufacturers, installers, and buyers of distributed wind turbines. From changes in federal and state incentive levels to innovations in technology and financing, these decisions and conditions impact the U.S. distributed wind market.

\subsection{Policies and Incentives}

Federal, state, and utility incentives and policies (e.g., rebates, tax credits, grants, net metering, production-based incentives, and loans) continue to play an important role in the development of distributed wind and other renewable energy projects. Incentive programs vary widely with respect to the amount of funding they provide, the total number of projects they support, and the length of time they are available.

Figure 9 provides the number of federal, state, and utility funding awards given in each state for distributed wind projects in 2015; the combined value of all awards equals $\$ 10.9$ million. ${ }^{9}$ This reflects a significant decrease from 2012, 2013, and 2014, when funding levels were $\$ 100$ million, $\$ 15.4$ million, and \$20.4 million, respectively. Reasons for the decline from 2014 include fewer states reporting incentive funding (10 states in 2015 compared to 14 states in 2014) and a lower amount of funding per award. In 2014, the average amount of incentive funding per award was $\$ 178,685$ compared to $\$ 79,620$ in 2015 .

Federal incentive programs play an important role in supporting clean energy deployment across the United States, including installations of distributed wind turbines. Figure 10 overlays introductions and changes in important federal policies, including the ITC and the Section 1603 cash grants, with domestic sales and imports from non-U.S. manufacturers of small wind turbines between 2003 and 2015. Two findings stand out here. The introduction of incentive funding and the ending of programs have a direct impact on the amount of sales in the United States. For example, the inclusion of small wind in ITC funding in 2008 was followed by four years of strong domestic sales. Conversely, the application deadline for Section 1603 cash grants in late 2012 was followed by three years of slower domestic sales.

Secondly, the phasing out of important federal incentive programs led to decreased interest of non-U.S. manufacturers of small wind in the American market. This finding was confirmed by interviews of importers that have all but abandoned the U.S. market in recent years.

\footnotetext{
${ }^{9}$ Incentive funding and commissioning of distributed wind projects often do not overlap. For example, although U.S. Department of Agriculture's (USDA's) Rural Energy for America Program (REAP) grants are recorded for this report in the year they are awarded, they are paid after the project is commissioned. Conversely, U.S. Department of Treasury 1603 program grants are recorded for this report in the year they are paid, which is also the year they are reported ${ }^{10}$ To qualify for 1603 payments, wind power projects must have been under construction or placed in service by the end of 2011 and must have applied for a grant by October 1, 2012. Some payments are still being made, as noted in Figure 9, because 1603 payments are made after the project is placed in service, not prior to, or during, construction. In 2015, 17 distributed wind projects received about $\$ 990,000$ in 1603 payments (Treasury 2016). This compares to 201 projects and \$63 million in 2012, 36 projects and \$7.6 million in 2013, and 11 projects and roughly \$650,000 in 2014.
} 


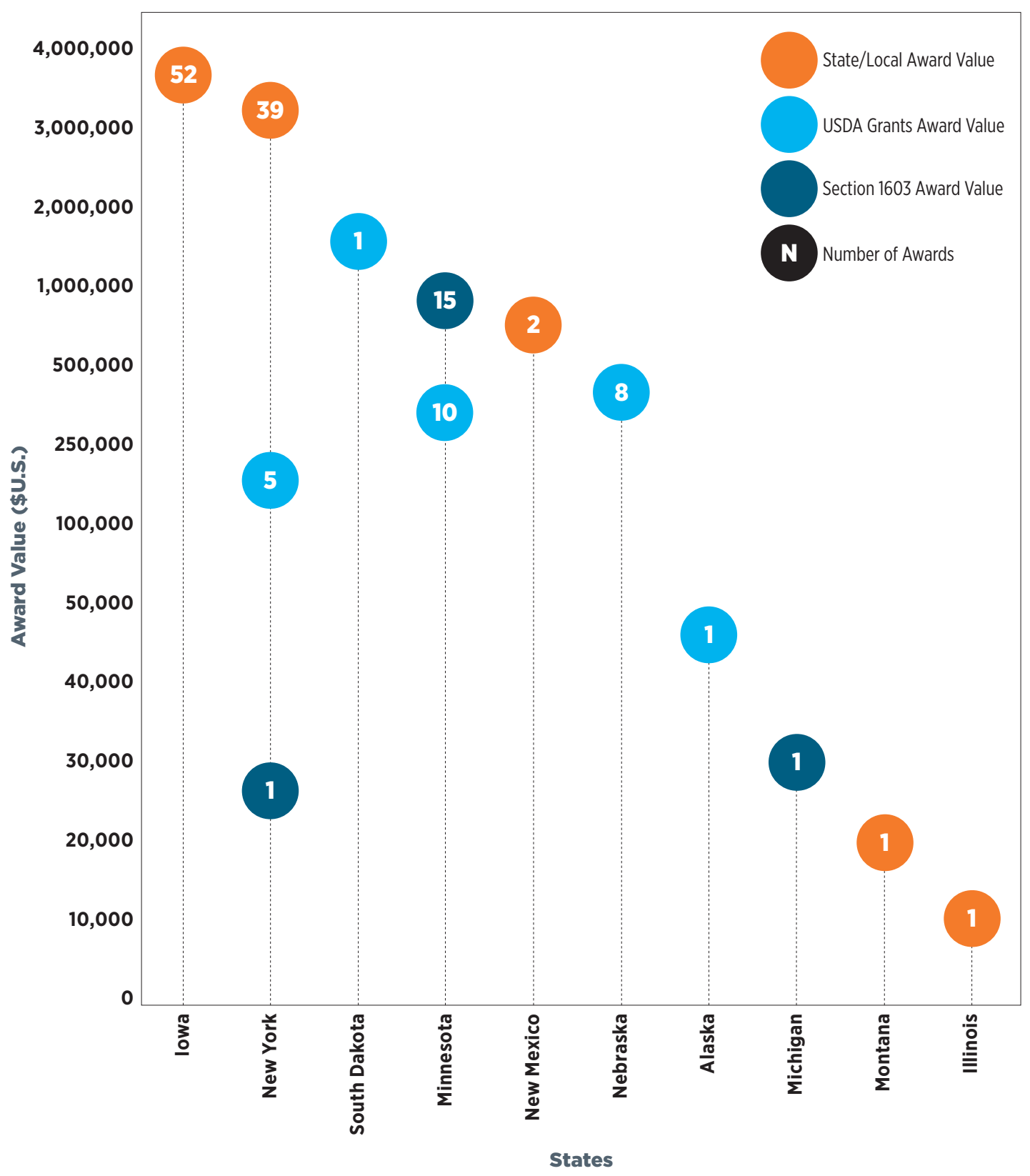

Figure 9. 2015 U.S. Distributed Wind Incentive Awards 


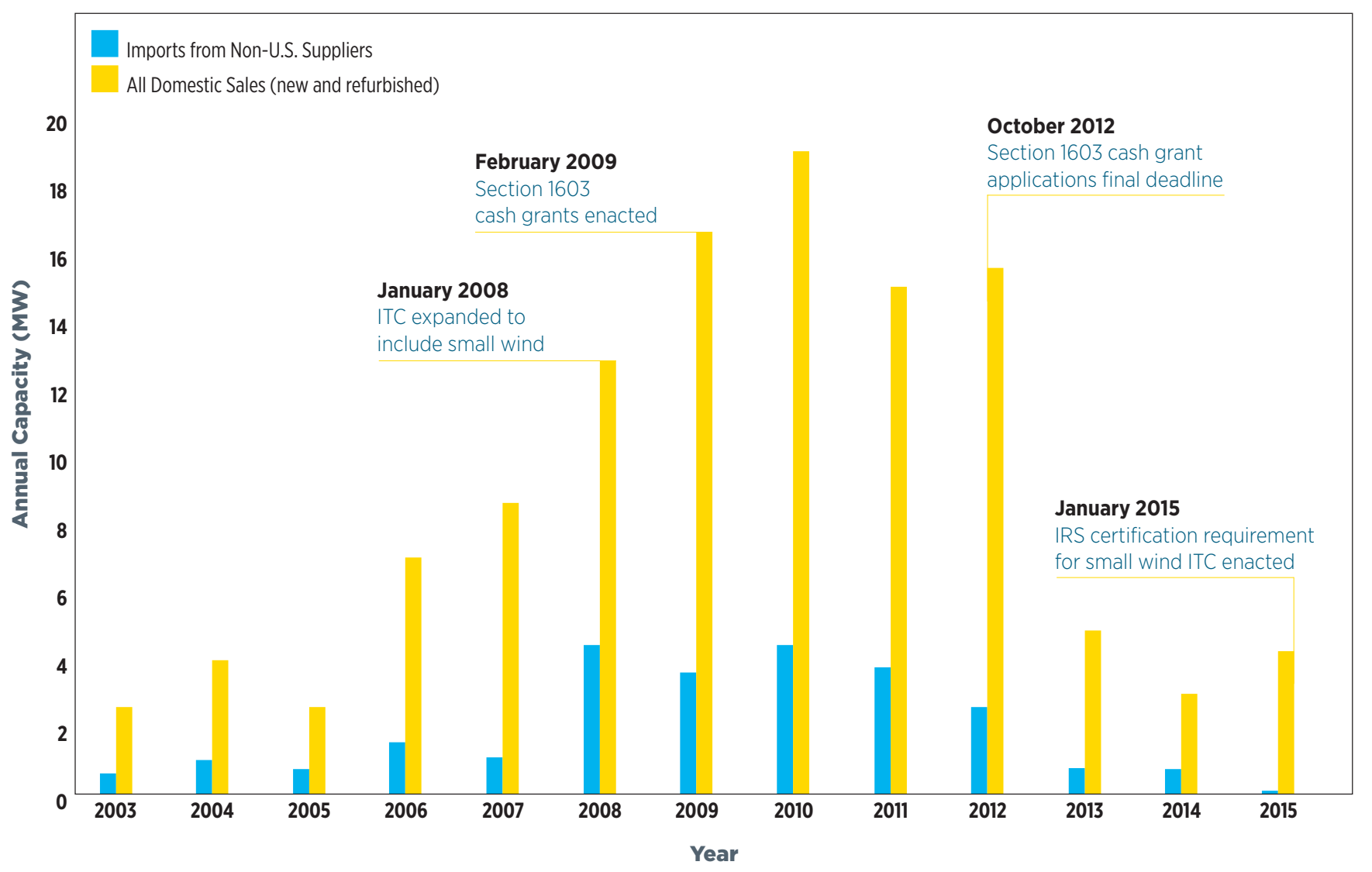

Figure 10. U.S. Small Wind Turbine Sales and Federal Policies, 2003-2015

\subsubsection{State Policies and Incentives}

State funding continues to play an important role in the distributed wind market, but fewer states are providing incentives. As mentioned in Section 4.1, 10 states offered incentives in 2015 compared to 14 states in 2014. As an example, California's Self-Generation Incentive Program has funded just one small wind turbine in the 2012 to 2015 timeframe. The 2015 small wind turbines installed in projects in California were not eligible for this incentive.

One successful program is the New York State Energy Research and Development Authority (NYSERDA) On-Site Small Wind Incentive Program. That program began in 2012 and expired at the end of 2015, but in May of 2016, NYSERDA announced it would make approximately $\$ 6$ million in incentives available for small wind through December 31, 2018 or until funds are fully committed, whichever comes first. This successor program is part of the state's new Clean Energy Fund. NYSERDA's program has effectively stimulated the state's distributed wind market by building a strong framework to balance financing, administrative, and quality hurdles that have historically constrained the adoption of distributed wind. Since 2012, the program has provided dedicated administrative support to help customers navigate the application process, has required wind turbines to be certified and installed by verified installers to be eligible for incentive funds, and has provided over \$7 million to projects totaling roughly $4 \mathrm{MW}$ from 2012 through 2015.

Favorable state policies are not limited to the availability of incentives, but also include effective permitting, net metering, and interconnection policies and procedures. For example, Ohio's net metering policy, with no system capacity limit, is a driver of the distributed wind projects installed in the state in 2015, which did not receive any state monetary incentives.

\subsubsection{Federal Tax-Based Incentives}

The federal Business Energy ITC (26 U.S.C. § 48) and the Residential Renewable Energy Tax Credit (26 U.S.C. § 25D) both provide a $30 \%$ credit against the capital costs of eligible renewable energy projects. The federal renewable electricity PTC (26 U.S.C. § 45) is an inflation-adjusted per-kilowatthour (kWh) tax credit for electricity generated by qualified energy resources and sold by the taxpayer to an unrelated person during the taxable year. In 2015, the PTC amounted to $\$ 0.023 / \mathrm{kWh}$ for wind projects. Several recent changes to these federal tax-based incentives are affecting the U.S. market for distributed wind. 


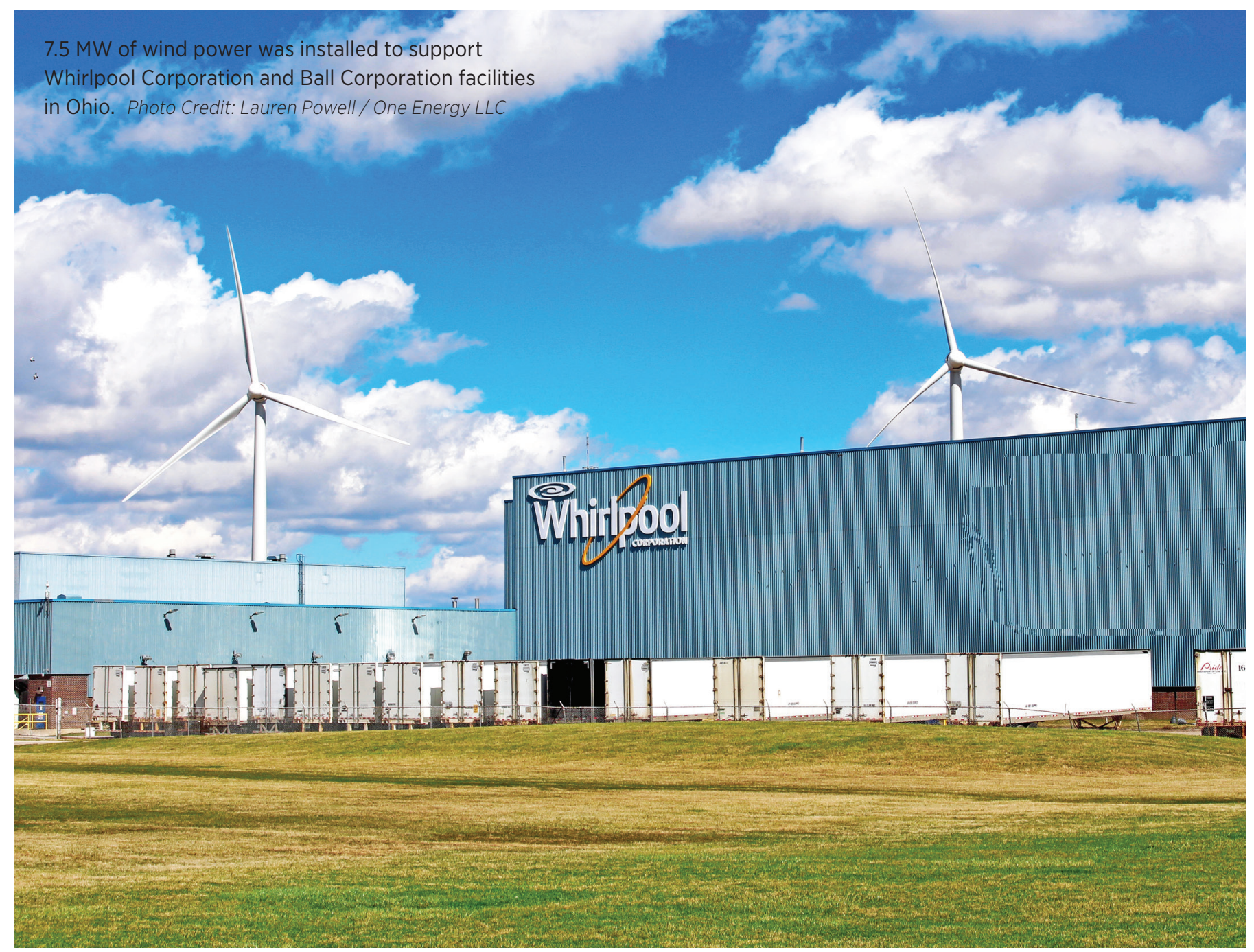

There have been two major recent changes to the ITC. As of January 2015, small wind turbines must be certified to either the American Wind Energy Association Small Wind Turbine Performance and Safety Standard 9.1-2009 or the International Electrotechnical Commission 61400-1, 6140012, and 61400-11 to be eligible to receive the Business Energy ITC or Residential Renewable Energy Tax Credit (IRS 2015)."

Secondly, the Consolidated Appropriations Act, signed in December 2015, extended the expiration date of the residential credit (26 U.S.C. § 25D) for solar PV and thermal technologies with a phase-down of the credit value through 2021. The Act did not extend the residential ITC for other technologies, such as small wind. Starting in 2022, qualifying solar technologies are still eligible for a 10\% federal Business Energy ITC (26 U.S.C. § 48), a permanent provision of the Act.

Information on how many small wind projects have claimed the federal Business Energy ITC and the Residential Energy Tax Credit is not public record; therefore, it is estimated that 3.4 MW of small wind turbines installed in grid-connected commercial, industrial, agricultural, and residential projects in 2015 received the $30 \%$ federal tax credit, representing a value of roughly $\$ 6$ million. ${ }^{2}$

Similar to the ITC, the federal PTC policy has been modified frequently leading to uncertainty in the market for potential customers, project developers, and manufacturers in terms of a stable long-term business strategy. The most recent modification came in December 2015 with the Consolidated Appropriations Act, which extended the expiration date of the PTC for wind projects which have begun construction by December 31, 2019, with a phase-down for wind projects beginning construction after December 31, 2016. After 2019, the PTC (and Business Energy ITC) will no longer be available for wind projects.

Since the adoption of the American Recovery and Reinvestment Act of 2009, projects eligible to take the PTC have been permitted to opt out of the PTC and instead receive the Business Energy ITC (26 U.S.C. § 48). For wind projects, the Consolidated Appropriations

\footnotetext{
${ }^{11}$ This certification requirement does not apply to qualified wind projects that elect to opt out of the PTC into the Business Energy ITC.

${ }^{12}$ This estimated amount is not included in the \$10.9 million total funding amount presented in Section 4.1.
} 
Act changes impose the same phase-down schedule and expiration date on the Business Energy ITC as the PTC. A wind project qualifies for the ITC until 2019 because it produces electricity from wind, a qualified energy resource listed in the Internal Revenue Code. The PTC requirement of electricity sales to an unrelated third party is not a requirement of the ITC.

There is no wind project size limitation for the PTC. A taxable business, with a wind project of any size, may elect to take the Business Energy ITC in lieu of the PTC. Neither the PTC nor the Business Energy ITC can be claimed for a residential wind project. Consequently, small wind projects, when structured accordingly, are eligible to receive the Business Energy ITC by first opting out of the PTC.

In support of the Consolidated Appropriations Act, the IRS issued new guidance in Notice 2016-31 as to what qualifies as "beginning of construction" (IRS 2016; Milder 2016). Many projects are expected to meet the begun construction requirement in 2016 in order to be eligible for the full PTC or 30\% Business Energy ITC before the phase-down schedule begins. For smaller projects, this start construction requirement is likely to be less beneficial because a small wind, single-turbine project takes months, not years, to develop and install. Even if a small wind project were structured to take the Business Energy ITC in lieu of the PTC, the reduced value of the ITC in future years is expected to be insufficient to drive interest in this approach, although larger projects may still elect to take the ITC in future years.

The Consolidated Appropriations Act also extended the bonus depreciation provision of the Modified Accelerated Cost-Recovery System (MACRS) depreciation schedule to December 31, 2019 with a phase-down schedule as well. Depreciation allows tax-paying entities to recover investments through depreciation deductions that offset taxable income. The bonus depreciation provision accelerates the claiming of depreciation even more for eligible equipment, including renewable energy projects, which would otherwise claim the five-year MACRS depreciation schedule, enabling additional tax savings to be claimed more quickly.

\subsubsection{USDA REAP}

The USDA provides agricultural producers and rural small businesses grant funding as well as loan financing to purchase or install renewable energy systems or make energy efficiency improvements. Through REAP, the USDA issues loan guarantees for up to $75 \%$ of the project's cost or a maximum of $\$ 25$ million for renewable energy projects. Grants are issued for up to $25 \%$ of the project's cost, or a maximum of $\$ 500,000$ for renewable energy projects. A combination of loans and grants can cover up to $75 \%$ of total eligible project costs.

With the passage of the 2014 Agricultural Act (the "Farm Bill"), Congress provided $\$ 880$ million for energy programs established in the 2008 Farm Bill (USDA 2014). USDA received new and sustained funding for REAP grants and loan guarantees which was applied to grant awards in the USDA's 2015 fiscal year. The Farm Bill made REAP the largest Farm Bill Clean Energy Program, with mandatory funding of $\$ 50$ million per year through 2018. An additional $\$ 81$ million in five-year discretionary funding was authorized for fiscal year 2016 (USDA 2016).

In 2015, USDA REAP funded 24 wind projects with almost $\$ 1.4$ million in grants, supporting projects costing just over $\$ 6.6$ million that are expected to generate $8.7 \mathrm{GWh}$ of energy annually. This reflects a significant increase from 2014 levels, when USDA provided $\$ 405,442$ in grants for 15 wind projects that cost $\$ 1.7$ million and generated $840 \mathrm{MWh}$ of energy annually. Table 2 summarizes the number of grants and funding amounts for wind awards from 2012 through 2015.

Wind projects represented $1.3 \%$ of all 2015 REAP awards in 2015 (1.7\% of REAP funding); energy efficiency projects represented $38 \%$ of awards (24\% of funding) and solar projects represented $54 \%$ of awards (54\% of funding). In 2014 , these numbers stood at $2.8 \%$ of all 2014 REAP awards (and received $0.6 \%$ of REAP funding) for wind projects; $47 \%$ of awards ( $8 \%$ of funding) for energy efficiency projects; and $44 \%$ of awards (88\% of funding) for solar projects. Other awards include biomass, geothermal, and hydroelectric projects. In $2015,83 \%$ of the applications for wind projects received REAP funding, while in 2014, this number stood at $54 \%$. The larger availability of funds might account for the difference between these years. These 2014 and 2015 comparisons are shown in Figure 11.

Table 2. USDA REAP Wind Awards, 2012-2015

\begin{tabular}{lcccc} 
& 2012 & 2013 & 2014 & 2015 \\
\hline Awards & 57 & 25 & 15 & 24 \\
\hline Grants (\$) & $2,554,043$ & $1,193,984$ & 405,442 & $1,395,748$ \\
\hline Loan Guarantees (\$) & $15,357,837$ & $4,207,205$ & $1,295,818$ & $5,207,360$ \\
\hline
\end{tabular}


2014 Awarded Funding

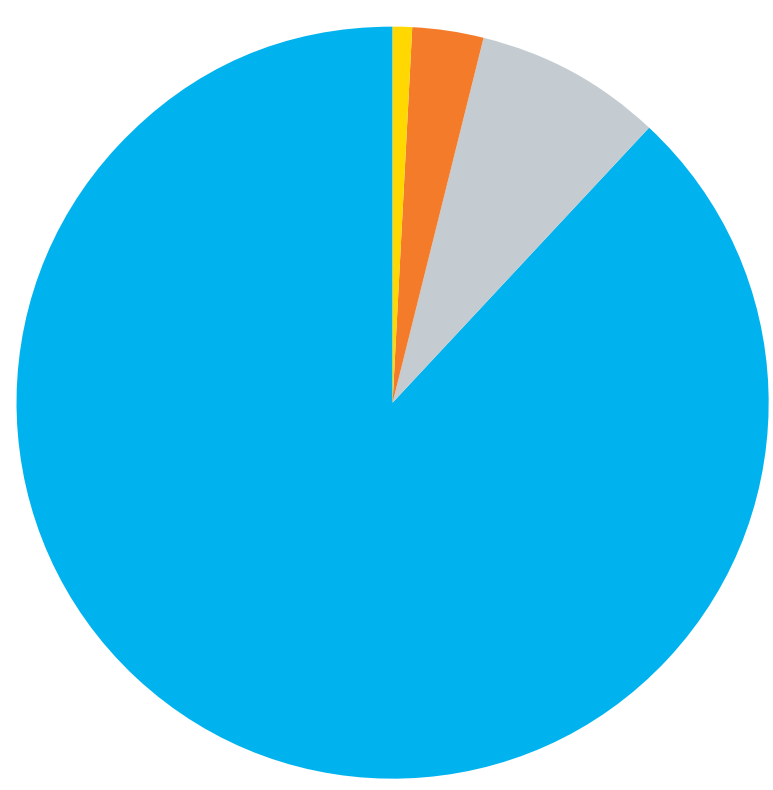

2015 Awarded Funding

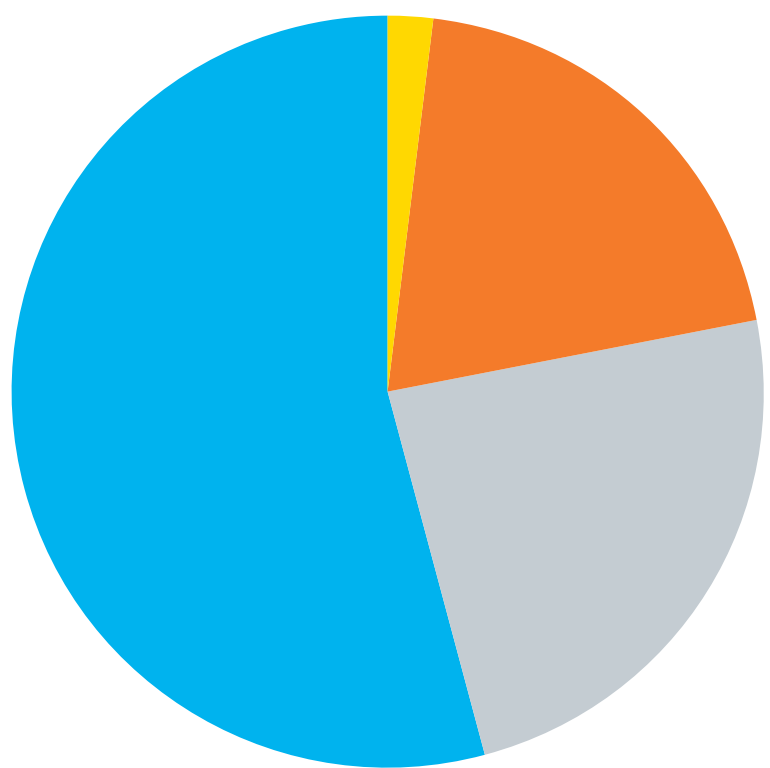

$\$ 1,395,748$

$\$ \mathbf{1 6 , 2 9 6 , 2 9 6}$

$\$ 20,132,690$

\section{$\$ 60,530,094 \quad$ Solar $\$ 45,154,364$}

$\begin{array}{lll}\$ 68,819,522 & \text { Totals } & \$ 82,979,098\end{array}$

Figure 11. 2014 and 2015 USDA REAP Awards

As Figure 11 shows, even as funding levels have dramatically increased between 2014 and 2015, the percentage of wind projects funded remains relatively low. Secondly, while the total amount of applications for wind funding decreased from 39 to 29 between 2014 and 2015, the amount of grant funding per application increased significantly.

Since 2003, total REAP grant funding made available has exceeded \$71 million, with Iowa (\$23.3 million), Minnesota (\$21.1 million), Illinois (\$4.1 million), Ohio (\$2.9 million), and Oregon (\$2.8 million) being the top five states in terms of total funding received. The top five states in terms of number of projects awarded are Iowa (263), Minnesota (168), New York (46), Wisconsin (45), and Alaska (30).

\subsection{Market Drivers}

The distributed wind market faces several challenges and opportunities. A general downward trend in state and federal incentive funding levels and programs, the relatively low cost of electricity, and the competition from solar PV, are some of the challenges. Many installers interviewed for this report commented that with accessible funding, relatively abundant incentive programs, and less complex permitting requirements, solar PV was the most important competitive challenge to distributed wind. Small wind and solar PV incentives are explored in Section 4.3.1.

An example of complex permitting requirements is Vermont's restrictions on sound levels from the operation of generation, transmission, and distribution equipment in the state. The Public Service Board of Vermont has jurisdiction over all energy projects in the state. While it has been considering establishing new sound standards in recent years, new wind project development has stalled (Vermont PSB 2014). In June 2016, the Governor of Vermont signed a renewable energy siting bill that addresses sound levels from wind generation (Vermont Business Magazine 2016). It requires the Public Service Board to adopt sound rules for wind generation facilities by July 1, 2017, extending the uncertainty for wind project developers to pursue new projects. 
With respect to financing, wind lease programs continue to be a driving force in the market with more companies adopting this business model. Lease arrangements and other third-party ownership models allow customers to host a wind turbine installed and owned by a third party on the customers' property. Customers then make monthly payments in exchange for the installation, operation, and maintenance of the wind turbine, and the energy produced on-site displaces their electricity consumption from the utility and thus lowers their utility bills.

The lease can include guaranteed performance, warranties, maintenance, and insurance - thereby transferring some of the key economic and risk barriers of distributed wind, including resource uncertainty, site-assessment costs, performance uncertainty, operational maintenance and reliability risks, and the high initial cost of installations, from the customer to the lessor company.

In January 2016, Northern Power Systems announced it is now offering a lease program in partnership with LFC Capital, Inc. (Jakovlev 2016). The traditional operating lease is structured so that the lessor, LFC Capital, can monetize federal tax credits that may not be available to potential commercial and industrial customers, particularly LLCs, and can offer the customer purchase options after six or seven years. In addition, in February 2014, another small wind turbine manufacturer, Xzeres, launched its PowerLease financing program (Xzeres 2014).

United Wind continues to be the main player in this space. In January 2016, the company announced it secured \$200 million in project equity capital from Forum Equity Partners to expand its lease program (United Wind 2016). According to NYSERDA records, United Wind financed five installed projects in New York in 2014 and 20 in 2015 (half of all installations in 2015 recorded by NYSERDA), while two more were installed but not fully commissioned by the end of 2015. United Wind reports that it has 166 projects in the pipeline for 2016 .

Other companies (e.g., One Energy LLC and Foundation Windpower) build, own, and operate on-site wind turbines and sell the power to customers through power purchase agreements (PPAs).

In all cases, companies offering third-party ownership of wind turbines are looking for a nexus of favorable conditions in three main factors to develop a successful project and to determine what geographic markets and customers to pursue. These factors are wind resource, policy environment, existing retail electric rates.

The primary siting consideration for any wind project is the wind resource. Next, these companies look for favorable policy environments. This is not limited to the availability of incentives, but includes the permitting, net metering, and interconnection policies and procedures as well. Finally, they are looking for areas with retail electric rates against which wind projects can be competitive.

United Wind has had success in New York, using the state as a proving ground for the lease program concept. The company is now expanding to Colorado, Kansas, Minnesota, and Iowa, where higher wind resources will compensate for a lack of cash-based incentives (in contrast to New York). Northern Power Systems' lease program target markets are New York, Colorado, and Kansas. All of Foundation Windpower's behind-the-meter projects are currently in California, but the company is interested in developing projects that can meet the three needed factors in other states.

The Distributed Wind Energy Association (DWEA) has a vision for $30 \mathrm{GW}$ of distributed wind installed by 2030 (DWEA 2015a). DWEA recognizes that this vision is dependent on the realization or maintenance of particular policies, actions, and technology improvements, such as wind lease programs, an extension of the federal small wind ITC, and other important market drivers.

\subsection{Solar PV and Distributed Wind Comparison}

The differences in the solar PV and distributed wind markets are stark, in terms of installed costs, available incentives, and installed capacities. Although a portion of these differences can be attributed to intrinsic siting requirements (i.e., solar PV can be installed on a roof, but a small wind turbine requires a plot of land which can influence both installed costs and the potential market size), this section of the report focuses on the incentive and installed cost differences. For solar PV, there is a wider variety of incentive platforms with deeper financial resources. Differences in funding incentives help explain why the solar PV market is more established than distributed wind.

\subsubsection{Incentives}

Financial incentives for renewable energy can take many forms - grants, tax credits, FITs, rebates, performance-based incentives, sales and property tax incentives, and loans. These can be offered by state government programs, local government programs, utilities, non-profits, and the federal government.

According to DSIRE records, as of May 2016 there were 565 different non-federal financial incentives available for solar PV across the United States. For small wind, this number is 270 .

With respect to rebate programs, there are 134 non-federal rebate programs for solar PV systems and 28 for small wind. Of the 134 solar PV programs, 24 are also available to small wind, meaning 110 of the programs are exclusively for solar PV. Of the 28 small wind rebate programs, only 4 are exclusive to small wind.

Similarly, there are 52 non-federal performance-based incentive (PBI) programs (i.e., incentives paid per kWh of generation) for solar PV and 17 for small wind. All of the 
Table 3. Solar PV and Small Wind Incentive Programs Comparison

\begin{tabular}{lcc} 
All non-federal financial incentive programs & $\begin{array}{c}\text { Solar PV } \\
\text { Number of } \\
\text { Programs }\end{array}$ & $\begin{array}{c}\text { Small Wind } \\
\text { Number of } \\
\text { Programs }\end{array}$ \\
Non-federal rebate programs & 565 & 270 \\
Non-federal rebate programs exclusive to technology & 134 & 28 \\
Non-federal PBI programs & 110 & 4 \\
Non-federal PBI programs exclusive to technology & 52 & 17 \\
\hline
\end{tabular}

small wind programs are also available to solar PV while 35 of the PBI programs apply only to solar PV. There are no exclusive small wind PBIs. This rebate and PBI program comparison is summarized in Table 3.

Because of the wide variety of incentives, this comparison analysis focuses on the non-federal residential rebate programs for solar PV (non-thermal) and small wind. In some cases, incentive rates for commercial or non-taxed entities are different.

PNNL was able to collect comparison data from 11 of the 24 rebate programs available to both small wind and solar $\mathrm{PV}$ to provide a snapshot of the differences in solar PV and small wind incentives. Table 4 compares incentive budgets, incentive rates, maximum payments, applications received, and applications funded.

Of the 11 programs in this analysis, 6 have equal incentive rates, 2 have a higher incentive rate for solar PV, and 3 have a higher incentive rate for small wind; however, in one case (i.e., Delaware Electric Cooperative) a lower maximum payment is imposed for small wind than for solar PV. Three programs have higher solar incentive budgets-Sulphur Springs Valley's solar budget is over $300 \%$ higher - and at least three programs share an incentive budget. Only two of the programs funded small wind turbines in 2015 (see Table 4).

Although incentive rates and program budgets are mostly equal, or share the same funding budget, for these highlighted programs, the number of solar PV funded projects is clearly higher than the number of small wind funded projects. Table 4 lists the number of projects funded by these select programs and the number of applications. While about $50 \%$ of both solar PV and small wind applications were funded, there were only six applications to two programs in 2015 for small wind. In contrast, many more solar PV applications were received in 2015 and 1,652 of them were funded. There are a couple of reasons why few small wind incentive applications are being submitted.

First, as discussed in Section 4.3.2, small wind installed costs are higher than those for solar PV. When equal incentives are provided, on a per $\mathrm{kW}$ basis, the solar incentive will cover much more of the initial capital cost than an equivalent incentive for wind. The consumer may decide that the out-of-pocket expense is still too high and will not result in a cost-effective small wind project and therefore does not submit an application.

For example, Guadalupe Valley Electric Cooperative offers a $\$ 1,000 / \mathrm{kW}$ incentive for solar PV and small wind up but only up to a maximum payment of $\$ 4,000$. According to the OpenPV Project, the average cost of solar PV installations in Texas in 2015 based on 28 projects totaling $250 \mathrm{~kW}$ was $\$ 2,949 / \mathrm{kW}$ (NREL 2016a). For a $10 \mathrm{~kW}$ solar PV system costing $\$ 29,490$, this incentive drops the upfront cost to $\$ 25,490$ - an almost $14 \%$ decrease. For an equivalently sized $10 \mathrm{~kW}$ wind turbine, the initial cost would be around $\$ 70,000$. The same incentive would reduce the small wind turbine's upfront cost to $\$ 66,000$ - just a $6 \%$ decrease. 
Table 4. Solar PV and Small Wind Rebate Program 2015 Funding Comparison

Central Lincoln People’s Utility District - Renewable Energy Incentive Program

City of San Marcos - Distributed Generation Rebate Program

Delaware Electric Cooperative - Green Energy Program Incentives

Farmers Electric Cooperative - Residential/Agricultural Energy Efficiency Rebate Program

Guadalupe Valley Electric Cooperative - Renewable Energy Rebates

Holy Cross Energy - Renewable Energy Rebate Program

NorthWestern Energy - USB Renewable Energy Fund

San Miguel Power Association - Renewable Energy Rebate Program

Solar and Wind Energy Rebate Program

Sulphur Springs Valley Electric Cooperative - SunWatts Rebate Program

\section{United Power - Renewable Energy Rebate Program}

State

OR

Solar PV Incentive Budget (\$)

25,000

TX DE

Small Wind Incentive Budget (\$)

25,000

45,000

167,516

TX TX

$\mathrm{CO}$

MT

CO IL

AZ CO

Solar PV Incentive

Rate $(\$ / \mathbf{k W})$

Maximum Payment (\$)

500

2,500

Small Wind Incentive

Rate $(\$ / \mathrm{kW})$

2,000

$5,000 \quad 5,000$

No Set
Amount $\quad$ 870,000 580,000

90,000

5,584

10,000

$1,251,000 \quad 6,000$

$\ddagger$

Maximum Payment (\$)

\begin{tabular}{l|l|l}
$500 \quad 1,000 \quad 1,250$ \\
\hline
\end{tabular}

\begin{tabular}{l}
$5,000 \quad 5,000 \quad 2,500$ \\
\hline
\end{tabular}

\# of Solar PV Applications

10

$\begin{array}{llll}8 & 50 & 18 & \ddagger\end{array}$

$\ddagger \quad \ddagger$

\begin{tabular}{ccccccc}
$\ddagger$ & 91 & 29 & 497 & 154 & $\ddagger$ \\
\hline & & & & & \\
& 1,000 & 63,500 & $1,100,000$ & 177,132 & $\ddagger$ \\
\hline
\end{tabular}

Solar PV Funded

(\$)

\begin{tabular}{ll}
\hline Total (kW) \\
\hline Total (\# of projects) \\
\hline
\end{tabular}

\# of Small Wind Applications

Small Wind Funded

(\$)

(\$)

(2)

7,205

000

\begin{tabular}{|c|c|c|c|}
52 & 115 & 193 & 85 \\
\hline 10 & 7 & 31 & 18
\end{tabular}

Total (kW)

Total (\# of projects)

$0 \quad 0 \quad 0$

0

$18 \quad 130 \quad 177$

† Not Applicable; ‡ Not Available * 850 for first 5kW, 250 for over 5 kW; ** 750 for first 6 kW, 500 for next 6 kW, 200 for next 13 kW;

*** 1,750 for certified turbines, 1,000 for non-certified 


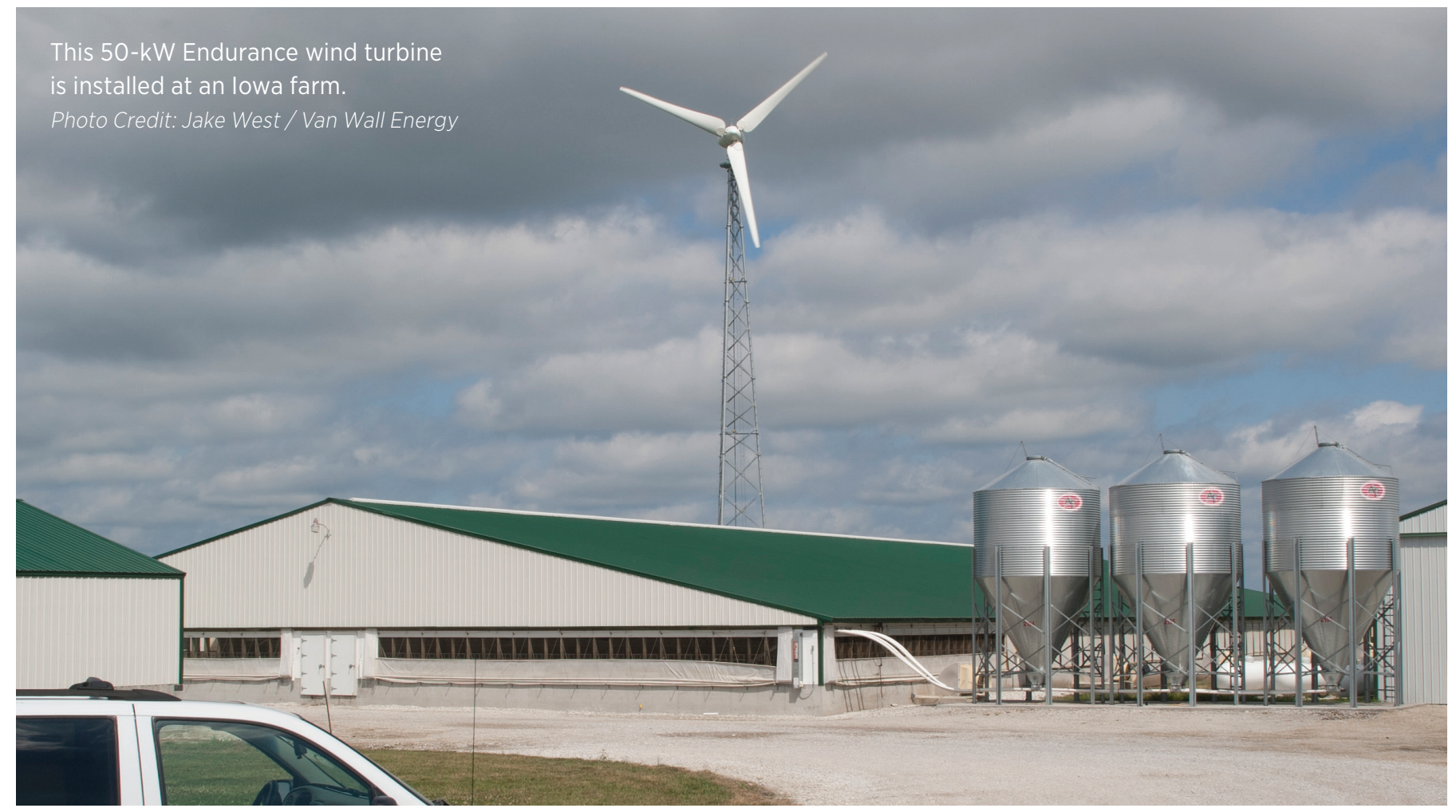

In contrast, NYSERDA's On-Site Small Wind Incentive Program, and its successor program, were designed to create an in-state distributed wind market and provide an incentive payment for up to $50 \%$ of the small wind turbine cost (through an incremental PBI payment system). In 2015, NYSERDA committed funding to 56 small wind projects.

United Power in Colorado has been lowering its rebate value for solar and wind as the cost of solar PV has dropped. The rebate was $\$ 100 / \mathrm{kW}$ in 2015 but was as high as $\$ 1,500 / \mathrm{kW}$ in the past. After a record year of 891 new solar PV systems installed totaling 5.7 MW in 2015, United Power is eliminating its renewable rebate program for 2016 for solar and wind. The utility believes its rebate has become immaterial to a customer's decision to install solar PV in light of the extension of the federal ITC for solar PV and the lower cost of solar PV. However, small wind costs have not decreased at the same rate and the ITC for small wind was not extended as it was for solar PV; still, the rebate for wind has been eliminated. United Power recognizes that its service territory does not have a strong wind resource; it had no applications for small wind rebates in 2015 and only has 11 installed small wind systems.

Another possible explanation for why far fewer small wind than solar PV incentive applications are being submitted, although an incentive may be offered, may be because the wind resource in the program's service territory is not sufficient to drive interest in and enable cost-effective wind energy projects. For example, Holy Cross Energy in Colorado offers the same incentive for both solar PV and small wind. Holy Cross's service territory is the western slope of the Rocky Mountains and includes the towns of Aspen, Glenwood Springs, and Rifle. According to the Colorado wind resource map (EERE 2014), this area has an average annual wind speed of $4 \mathrm{~m} / \mathrm{s}$ at a height of $30 \mathrm{~m}$, the minimum considered suitable for a small wind project. However, in comparison, for the 48 small wind projects installed in 2015 for which PNNL has reported hub heights and wind speeds, the average wind speed was $5.65 \mathrm{~m} / \mathrm{s}$ and the average hub height was $38 \mathrm{~m}$.

Based on the analysis of these selected incentive programs, low incentive values are not sufficient to drive adoption and the availability of an incentive may be inadequate to drive adoption in an area with a low wind resource.

\subsubsection{Installed Costs}

The Tracking the Sun VIII report (Barbose and Darghouth 2015) focuses on non-utility-scale solar PV installations and breaks this market into three segments: residential, nonresidential up through $500 \mathrm{~kW}$, and non-residential greater than $500 \mathrm{~kW}$ but only up through $5 \mathrm{MW}$.

This comparison focuses on small wind and residential solar PV installations. Although this report does not use the same segmentations as the Tracking the Sun report, large-scale distributed wind turbines, those greater than $1 \mathrm{MW}$, compare most logically to utility-scale solar PV installations. Mid-size distributed wind installations might compare to the nonresidential up through $500 \mathrm{~kW}$ solar PV market segment, but because of limited data for mid-size installations, mid-size is excluded from this analysis.

The Tracking the Sun report presents different median installed costs for each segment based on a data sample. The dollar values of the solar PV costs are presented as real 2014 dollar values; therefore, historical distributed wind installed costs were converted to 2014 dollar values for comparison purposes as shown in Figure 12. 
10,000

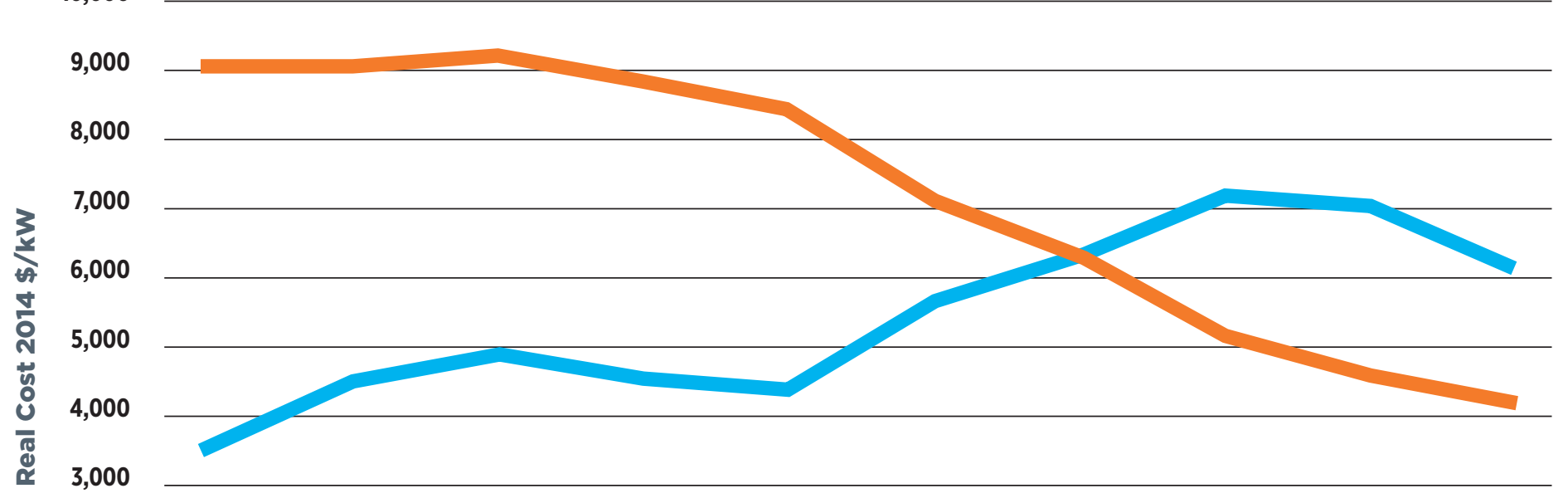

2,000

1,000

0

\begin{tabular}{llllllllll}
2005 & 2006 & 2007 & 2008 & 2009 & 2010 & 2011 & 2012 & 2013 & 2014 \\
\multicolumn{4}{c}{ Year }
\end{tabular}

Figure 12. Small Wind and Residential Solar PV Installed Costs

Solar PV installed costs have been dropping over the years due to declines in both module costs and non-module costs, such as inverters, racking equipment, and soft costs (e.g., marketing and customer acquisition, system design, installation labor, permitting and inspection costs, and installer margins). In addition, as demand for solar PV increases, production of PV modules can enjoy the benefit of economies of scale, helping to further decrease installed costs. According to SEIA/GTM Research (SEIA 2015), $1,265 \mathrm{MW}$ of residential solar PV capacity was installed in 2014 and $796 \mathrm{MW}$ in 2013. Solar PV installations are on a much greater scale than small wind with $3.7 \mathrm{MW}$ of small wind capacity deployed in 2014 and 5.6 MW in 2013.

From 2008 to 2012, the drop in price of PV modules, mainly due to the drop in cost of crystalline silicon, was the driving force behind the drop in the overall installed cost of PV systems. Since 2012, installed prices have continued to drop but because of a decrease in non-module costs. These non-module cost reductions come from declines in inverter and racking equipment costs, increasing module efficiency, and declines in soft costs (Barbose and Darghouth 2015).

In recent years, there have been focused efforts to reduce soft costs for solar PV systems, most notably by the U.S. DOE SunShot Initiative. Launched in February 2011, SunShot is DOE's collaborative national effort with private companies, universities, non-profit organizations, state and local governments, and national laboratories to make solar energy fully cost-competitive with traditional energy sources. SunShot's goal is to drive down the cost of solar electricity to $\$ 0.06 / \mathrm{kWh}$, without incentives, by the year 2020 by funding research and development and other efforts.

While falling costs have helped drive increases in solar PV installed capacity, other market factors have also played a role, notably the introduction of the lease model. For example, founded in 2006, SolarCity was one of the pioneers of the lease model for residential solar PV, with other companies quickly following. Today, third-party financing of solar PV is the predominant business model for residential solar (Kann 2013). As discussed in Section 4.2, the leasing model is now being used in the distributed wind market.

In contrast, small wind costs have been mostly increasing because of various factors, although costs are now trending downward, as shown in Figure 12. These factors include changes in hardware costs, soft costs, and the marketplace. 
The overall wind market saw turbine costs increase from 2002 through 2008 and then decline as a result of domestic and global changes in labor costs, warranty provisions, manufacturer profitability, turbine scaling, raw materials prices, energy prices, and foreign exchange rates (Wiser and Bolinger 2015). The cost of rare earth metals is one example of how fluctuating raw material costs can have an impact on small wind installed costs. Chinese dominance of the rare earth metals market peaked in 2010 when the country controlled about $95 \%$ of the world's rare earth metal production and the country imposed export limits, thereby driving prices up rapidly (King 2016). Many distributed wind turbines employ purpose-built direct-drive permanent magnet alternators using rare-earth magnets (DWEA 2016). This may account for some of the rise in the small wind installed cost between 2009 and 2012 shown in Figure 12. One small wind installer interviewed for this report stated that the cost of a magnet for a turbine model he regularly installs - with an overall installed cost of roughly $\$ 90,000$ - increased by $\$ 3,000$ in one year. Since that spike, manufacturers have sought alternatives and rare earth metal production outside of China has increased, helping to drive down rare earth metals' costs.

Just as with solar PV, soft costs play a role in small wind installation costs; however, one soft cost the solar PV industry does not have is the cost of certification to be eligible for federal, and some state, incentives. As of January 2015, small wind turbines must be certified to be eligible for the federal $30 \%$ ITC, a requirement that was recommended by the distributed wind industry (DWEA 2015b). Small wind is the only technology that has this requirement. NYSERDA also requires small wind turbines to be certified to be eligible for its incentive. Table 5 lists the small and medium ${ }^{13}$ wind turbines certified $^{14}$ as of May 2016 by the Small Wind Certification Council (SWCC) or Intertek.

Table 5. Certified Small and Medium Wind Turbines (IREC 2016)

\begin{tabular}{|c|c|c|c|c|c|}
\hline Applicant & Turbine & Certifier & $\begin{array}{c}\text { Rated Annual Energy }{ }^{1} \\
@ 5 \mathrm{~m} / \mathrm{s}(\mathrm{kWh})\end{array}$ & $\begin{array}{l}\text { Rated Sound } \\
\text { Level }^{2}(\mathrm{~dB}(\mathrm{~A}))\end{array}$ & $\begin{array}{c}\text { Certified Power } \\
\text { Rating' @ } 11 \mathrm{~m} / \mathrm{s}(\mathrm{kW})\end{array}$ \\
\hline Bergey Windpower & Excel 6 & SWCC & 9,920 & 47.2 & 5.5 \\
\hline Bergey Windpower & Excel 10 & SWCC & 13,800 & 42.9 & 8.9 \\
\hline Eveready Diversified Products & Kestrel e400nb & SWCC & 3,930 & 55.6 & 2.5 \\
\hline Kingspan Environmental & KW6 & SWCC & 8,950 & 43.1 & 5.2 \\
\hline Osiris Technologies & Osiris 10 & Intertek & 23,700 & 49.4 & 9.8 \\
\hline Pika Energy & T701 & SWCC & 2,420 & 38.3 & 1.5 \\
\hline Sonkyo Energy & Windspot 3.5 & Intertek & 4,820 & 39.1 & 3.2 \\
\hline Sumec Hardware \& Tools Co. LTD & PWB01-30-48 & Intertek & 2,920 & 41.1 & 1.2 \\
\hline Sumec Hardware \& Tools Co. LTD & PWA03-44-250 & Intertek & 6,400 & 40.9 & 3.2 \\
\hline Sumec Hardware \& Tools Co. LTD & PWB02-40-48 & Intertek & 4,660 & 36.9 & 1.7 \\
\hline Sumec Hardware \& Tools Co. LTD & PWA05-50-280 & Intertek & 9,240 & 42.0 & 5.0 \\
\hline Xzeres Wind Corporation & 442SR & SWCC & 16,700 & 48.5 & 10.4 \\
\hline Xzeres Wind Corporation & Skystream 3.7 & SWCC & 3,420 & 41.2 & 2.1 \\
\hline
\end{tabular}

'Estimated annual energy production assuming an annual average wind speed of $5 \mathrm{~m} / \mathrm{s}$ (11.2 $\mathrm{mph}$ ), a Rayleigh wind speed distribution, sea-level air density, and $100 \%$ availability. Actual production will vary depending on site conditions.

${ }^{2}$ The sound level that will not be exceeded $95 \%$ of the time, assuming an annual average wind speed of $5 \mathrm{~m} / \mathrm{s}$, a Rayleigh wind speed distribution, sea-level air density, 100\% availability and an observer location $60 \mathrm{~m}$ from the rotor center.

${ }^{3}$ Power output at $11 \mathrm{~m} / \mathrm{s}(24.6 \mathrm{mph})$ at standard sea-level conditions. Manufacturers may describe or name their wind turbine models using a nominal power, which may reference output at a different wind speed (e.g. $10 \mathrm{~kW}$ Bergey Excel 10).

\footnotetext{
${ }^{13}$ International and domestic certification standards define wind turbines based on their rotor swept area, rather than their nominal capacity. For certification purposes, small wind turbines are those having rotor swept areas up to $200 \mathrm{~m}^{2}$ (approximately 50 to $65 \mathrm{~kW}$ ) and medium wind turbines are those having rotor swept areas greater than $200 \mathrm{~m}^{2}$.

${ }^{14}$ The standards for certification used are the AWEA Small Wind Turbine Performance and Safety Standard 9.1-2009 with power performance ratings, sound level ratings, and design and duration test compliance; and, the International Electrotechnical Commission (IEC) 61400-12-1 (power) and IEC 61400-11 (acoustics) standards. In 2014 and 2015, an updated version of the AWEA standard was drafted and reviewed (AWEA SWT-1-201X) and is expected to be adopted in 2016. When adopted, it will replace the 2009 version.
} 
Meeting performance and quality standards through the certification process ${ }^{15}$ presents both challenges and opportunities for manufacturers. It benefits manufacturers by raising their competitiveness and increasing consumer, government agency, and financial institution confidence in distributed wind projects. However, undergoing the certification process is a business investment decision that is costly to manufacturers. One manufacturer reports that certification of one turbine model to American Wind Energy Association (AWEA) 9.1-2009, with the associated Underwriters Laboratory certifications, costs between $\$ 150,000$ and $\$ 225,000$ with all fees, direct expenses, and employee labor time included. To put that number in perspective, another manufacturer, Xzeres Corporation, publicly traded in 2015, reported revenues of \$4.4 million for its fiscal year 2015 (SEC 2015) and has two certified turbine models.

Finally, market conditions likely play a role in the installed cost of small wind. As the market has matured, the industry has contracted and the number of small wind turbine manufacturers has decreased. In 2012, 31 companies reported U.S. sales; in 2015 that number dropped to 10 . Some companies who sold noncertified turbines, such as Franklin, DyoCore, and Enertech, are no longer in business.

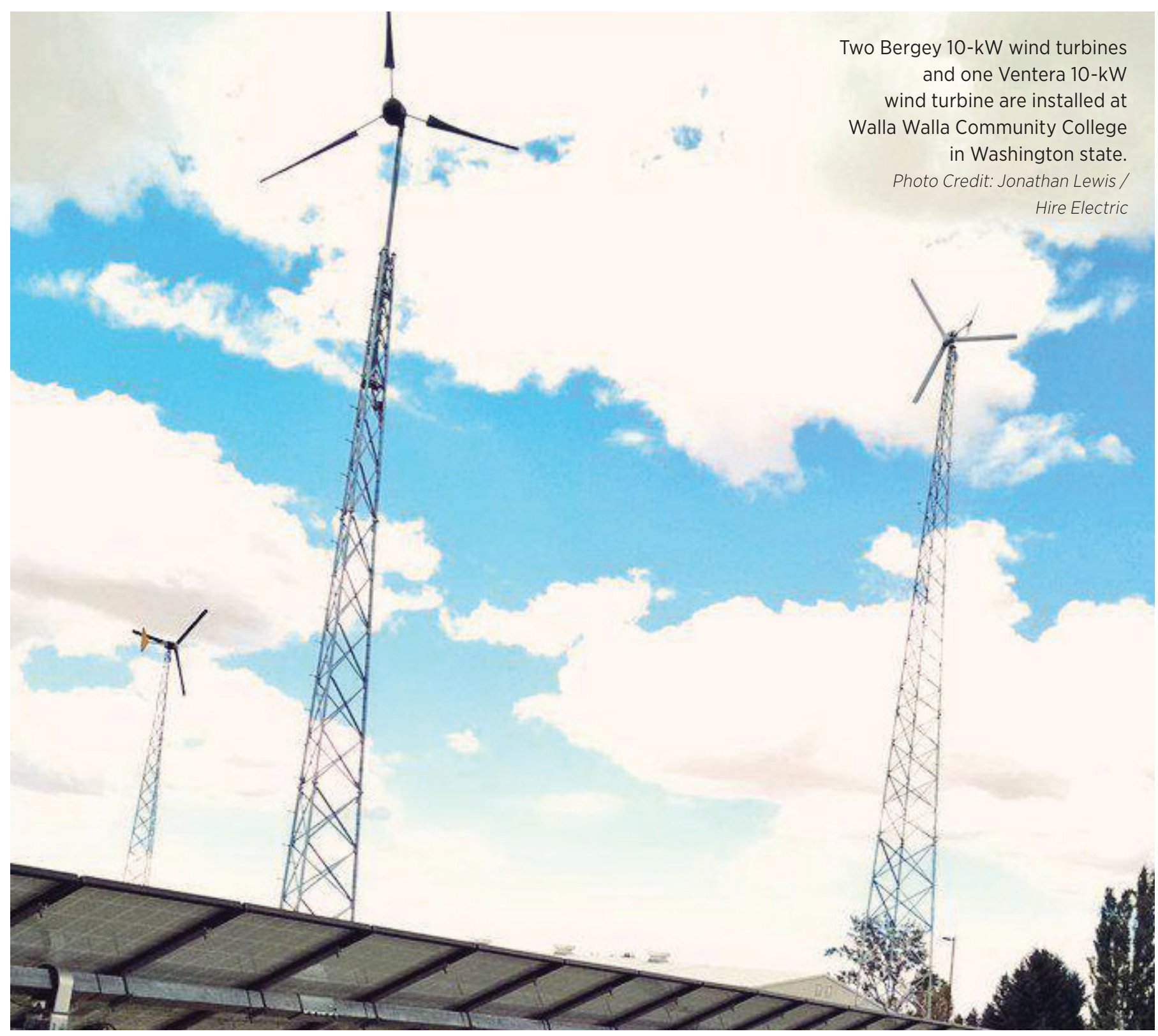

${ }^{15}$ As of May 2016, 13 different small turbine models are fully certified to AWEA Standard 9.1-2009, four medium wind turbine models have published power performance and acoustics certifications to IEC 61400-12-1 (power) and IEC 61400-11 (acoustics), and 17 additional wind turbine models have conducted testing or have pending applications. The number of turbine models in each category fluctuates at any given time. In some cases, a manufacturer may have received conditional certification, but then did not meet additional requirements to obtain full certification. In addition, the SWCC requires an annual renewal of certification, and a manufacturer may opt not to renew a certification. Six small wind turbine certifications were renewed by SWCC in 2015 . 


\subsection{Installed, O\&M, and Soft Costs}

Cost data in this section were derived from manufacturers, state and federal agencies, project owners and developers, installers, and news reports.

\subsection{Small Wind Installed Costs}

Due to substantial differences in costs of various wind turbine models, tower types and heights, and manufacturer methodology for setting nominal power ratings and estimating installation expenses, a wide range of costs was reported in 2015 for wind technologies used in distributed applications. Because the wide range of small wind turbine sizes (i.e., $<1$ to $100 \mathrm{~kW}$ ) dictates a wide range of costs, it is appropriate to examine costs of small wind turbines in smaller groups.

Figure 13 presents the nominal installed costs for newly manufactured small wind turbines installed in the United States as reported by the manufacturers from 2005 through 2015. For 2012 through 2015, the costs of small wind are also categorized into three different size ranges: less than $2.5 \mathrm{~kW}, 2.5$ to $10 \mathrm{~kW}$, and 11 to $100 \mathrm{~kW}$.
Small wind turbine installed costs are trending downward, driven mainly by the cost of turbines in the 11 to $100 \mathrm{~kW}$ size range. Based on small wind turbine manufacturers' reports, the overall capacity-weighted average installed cost of 1.6 MW of newly manufactured small wind turbines sold in the United States in 2015 was $\$ 5,760 / \mathrm{kW}$. This compares to $\$ 6,230 / \mathrm{kW}$ in 2014 from $2.8 \mathrm{MW}$ of sales and $\$ 6,940 / \mathrm{kW}$ in 2013 from 5 MW of sales.

Figure 14 shows reported project-specific installation costs for a sample of 2015 projects representing 1.8 MW and 75 wind turbines across 13 states. Note that Figure 14 includes only those 2015 small wind projects for which cost information was available and that those costs are before any incentives. Most outliers, which are circled, can be explained by their higher cost location (e.g., Hawaii and Alaska) or by the use of a higher cost per $\mathrm{kW}$ vertical-axis wind turbine (VAWT).

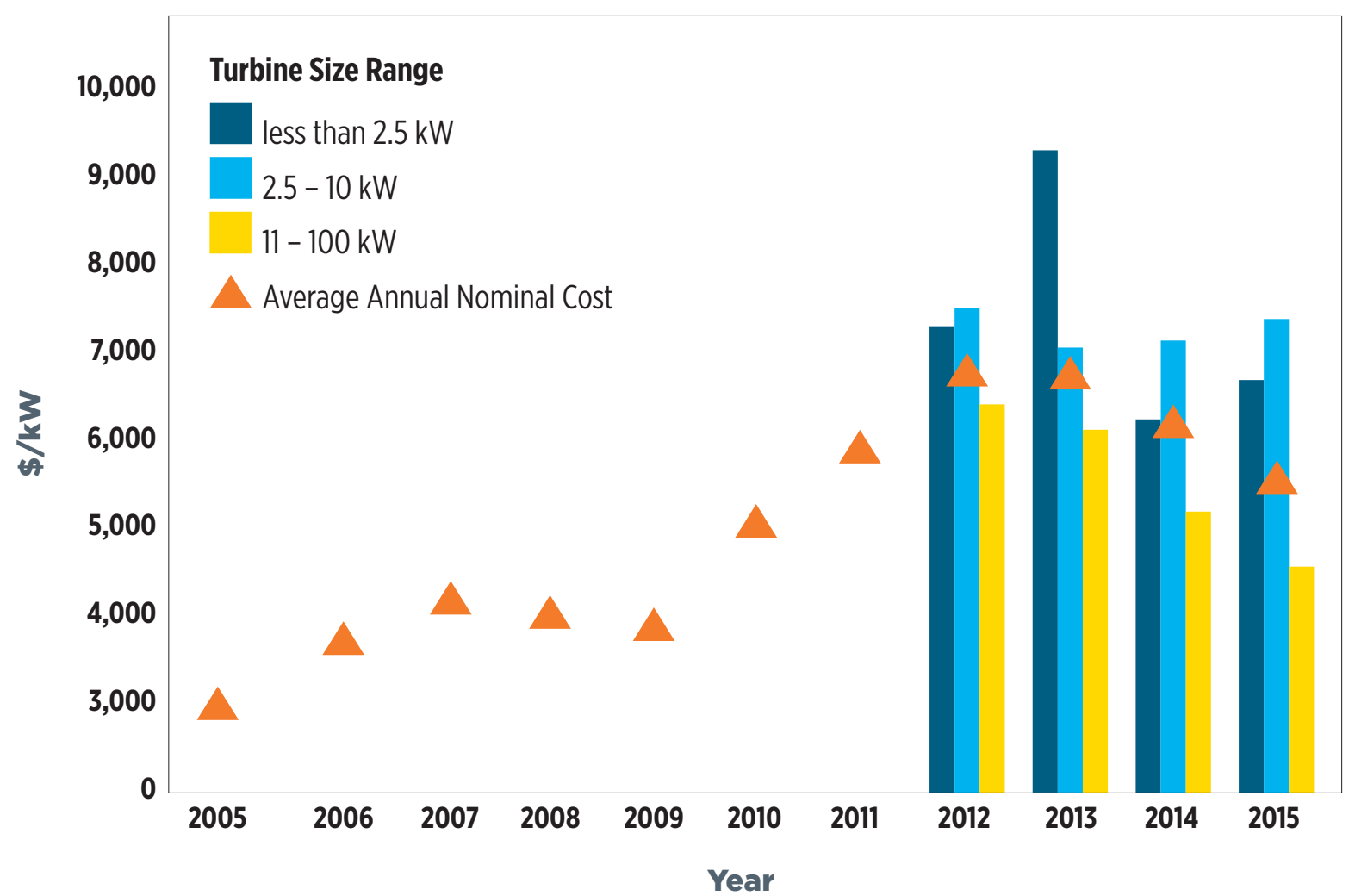

Figure 13. Nominal Newly Manufactured U.S. Installed Small Wind Turbine Costs Reported by Manufacturers 


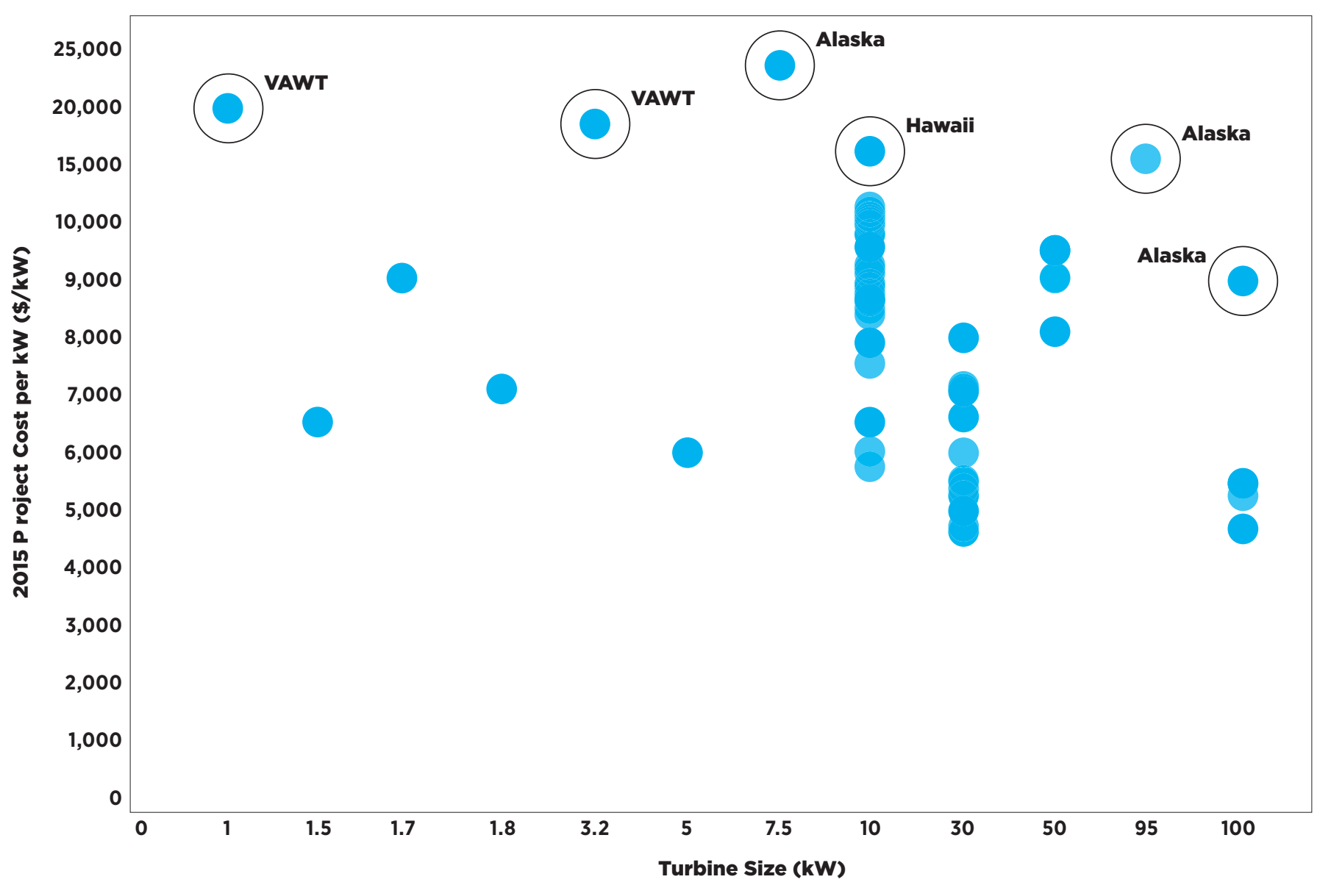

Figure 14. 2015 Small Wind Project Costs

The capacity-weighted average installed cost of this sample of projects is $\$ 7,820 / \mathrm{kW}$ and $\$ 6,940 / \mathrm{kW}$ without the circled outliers, both of which are higher than the $\$ 5,760 / \mathrm{kW}$ overall small wind capacity-weighted average as reported by manufacturers. ${ }^{16}$ While the manufacturers provide a typical installed cost estimate for each turbine model, the data suggest that actual installed costs are impacted greatly by site-specific issues, such as foundation and construction requirements, local installation labor, permitting requirements, and shipping costs.

Built-environment wind turbine (BEWT) projects are wind energy projects constructed on, in, or near buildings. Many of these installations use VAWT models. These projects present an opportunity for distributed, low-carbon generation combined with highly visible statements on sustainability; however, the BEWT niche of the wind industry is still developing. In order to address the lack of publically available data on this topic, DOE has published a report that includes case studies of several real-world BEWT projects, extracts the risks and lessons learned, and includes recommendations for safe and effective execution of BEWT projects (NREL 2016b). The case studies indicate that even with higher installed costs and system under performance (i.e., low capacity factors), some projects are still considered successful for reasons unrelated to performance and economics.

\subsection{Installed Costs for Projects Using Wind Turbines Greater than $100 \mathrm{~kW}$}

Compared to large wind farms using turbines greater than $100 \mathrm{~kW}$, distributed wind projects tend to have higher costs per $\mathrm{kW}$ for two primary reasons. First, with respect to project size, distributed wind projects often employ a small number of turbines, or even a single wind turbine, and do not benefit from the economies of scale available to larger projects. Turbine manufacturers may charge more for a single turbine order than for a bulk turbine purchase. Second, distributed wind projects

${ }^{16}$ The known project-specific costs and the manufacturers' reported average costs were more similar in 2013 and 2014 . For the sample of 2014 projects analyzed in last year's report, the capacity-weighted average installed cost was $\$ 6,687 / \mathrm{kW}$ compared to the manufacturers' reported average of $\$ 6,230 / \mathrm{kW}$. For the sample of 2013 projects analyzed in last year's report, the capacity-weighted average installed cost was $\$ 6,657 / \mathrm{kW}$ compared to the manufacturers' reported average of $\$ 6,940 / \mathrm{kW}$. The 2013 and 2014 project sample size totaled $3.4 \mathrm{MW}$ and 129 turbines. 
that use larger turbines are often installed in remote or unique locations that necessitate additional costs, such as islands (which require increased transportation costs), military installations, and manufacturing facilities (where limited site accessibility may increase labor costs).

For turbines greater than $100 \mathrm{~kW}$ installed in the United States in 2015, project cost information was available for five projects representing 14.5 MW and eight turbines in four states. The capacity-weighted average cost of these projects is $\$ 3,433 / \mathrm{kW}^{17}$

\subsection{O\&M Costs}

Determining operations and maintenance (O\&M) costs for distributed wind projects is challenging. Because there is no standard reporting method, O\&M cost reports vary widely depending on perspective. From the O\&M service provider's perspective, O\&M costs depend on the provider's proximity to the project site (i.e., travel costs), support from the wind turbine manufacturer (i.e., availability of spare parts), and the complexity of maintenance or repairs. However, manufacturers' estimates of O\&M costs may only consider parts and materials costs, not the labor or travel costs of the service provider. O\&M service providers and turbine manufacturers provided O\&M costs for a limited sample of distributed wind projects using a range of turbine models for this report. Average O\&M costs were derived from these reports to use in the levelized cost of energy (LCOE) calculations reported in Section 7.0.

\subsection{Turbine System Equipment and Soft Costs}

The turbine system equipment, or the hardware components of a turbine (i.e., blades, nacelle assembly, tower, inverter, electronics, and controls), accounts for up to $60 \%$ of the total installed cost of a distributed wind project per manufacturers and installers interviewed for this report.

To support the reduction of these hardware costs, make wind energy cost-competitive with other distributed generation technology, and increase the number of wind turbine designs certified to national testing standards, the DOE Competitiveness Improvement Project (CIP) awards costshared grants via a competitive process to manufacturers of small and medium wind turbines. As of May 2016, DOE has awarded 16 subcontracts to nine manufacturers, totaling $\$ 3.9$ million of investment for turbine testing, system optimization, and advanced manufacturing efforts.

As discussed in Section 4.3.2, soft costs play a role in installed costs. The other $40 \%$ of the total installed cost of a distributed wind project are the soft costs: installation labor and tools; transportation; sales tax; zoning, permitting, inspection, interconnection, and incentive labor and fees; engineering and design (e.g., site assessment, foundation design, and geotechnical report); financing; overhead; and profit.

DOE has initiated a study to quantify distributed wind soft costs to identify opportunities for reducing soft costs in the future, similar to the DOE SunShot Initiative. As a first step, cost data are being collected from a diverse group of installers, representing both geographical and turbine model diversity. Having this baseline information will allow DOE and industry to track cost and labor trends, and to make better-informed decisions on future efforts to reduce the soft costs of distributed wind and, thereby increase the number of deployments.

\footnotetext{
${ }^{17}$ For the 2014 distributed wind projects using turbines greater than $100 \mathrm{~kW}$, the capacity-weighted average cost was $\$ 2,996 / \mathrm{kW}$. In 2013 , it was $\$ 2,935 / \mathrm{kW}$. The 2013 and 2014 project sample size totaled $24 \mathrm{MW}$ and 16 turbines.
} 


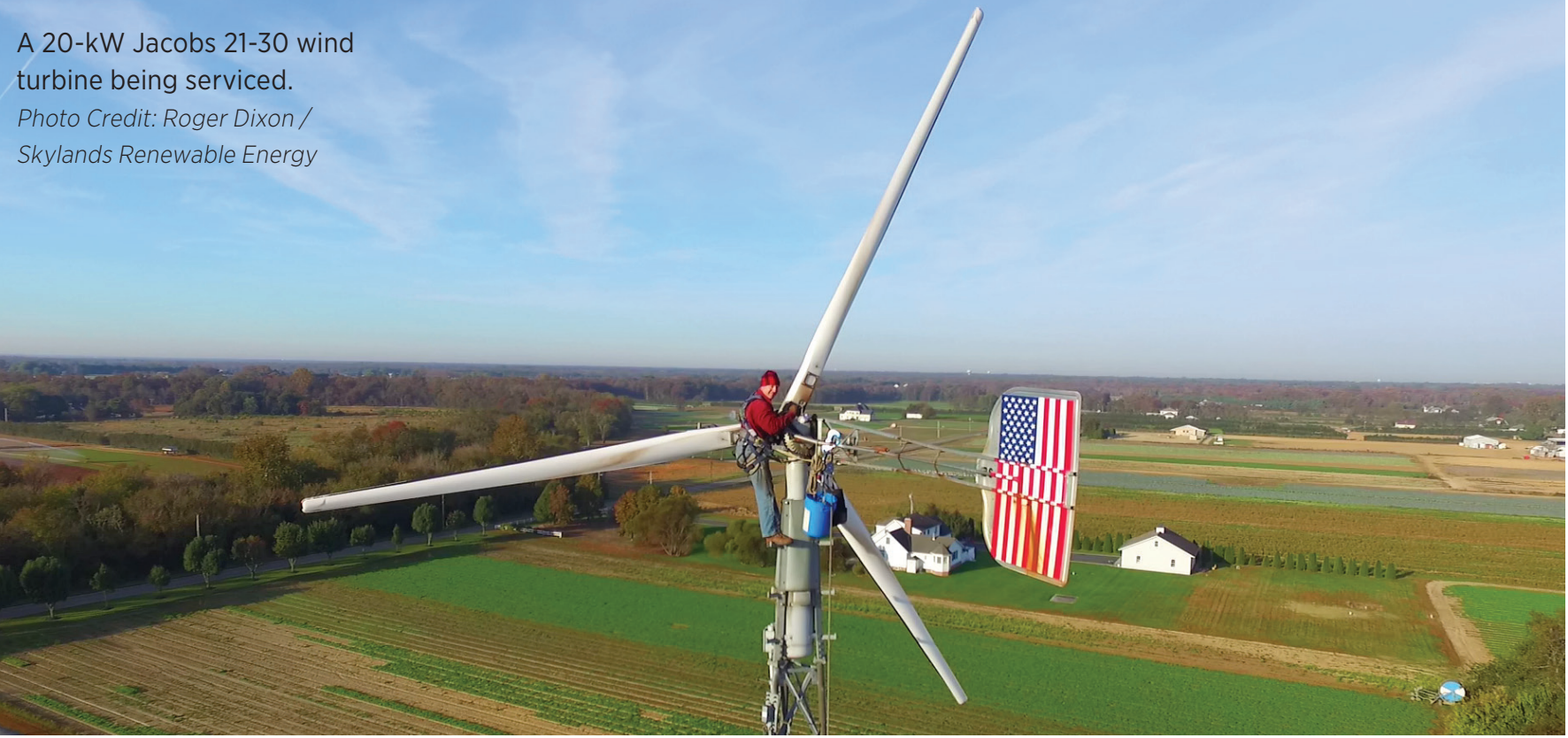

\subsection{Performance}

A wind project's capacity factor is one way to measure the project's performance. Capacity factor is a project's actual annual energy production divided by its annual potential energy production if it were possible for the wind turbine to operate continuously at its full nominal capacity. ${ }^{18}$

The capacity factors shown in Figure 15 for a sample of 2015 small wind projects were estimated based on projected performance reports from developers, installers, USDA REAP, and state incentive programs. The majority of the projects received an incentive from USDA REAP or NYSERDA, which require the applicant to work with a trained installer and use technology with proven performance to provide an energygeneration estimate with the application. Nonetheless, these are projected capacity factors. The sample size is $3.6 \mathrm{MW}$ from 66 projects in 12 states. The estimated capacity-weighted average capacity factor for these projects is $32 \%$. In comparison, the 120 projects totaling $19.3 \mathrm{MW}$ from 2013 and 2014 in 15 states analyzed for last year's market report had a capacity-weighted average capacity factor of $25 \%$.

The 2014 capacity factors from 52 different distributed wind projects using turbines greater than $100 \mathrm{~kW}$, with a total project size of at least $1 \mathrm{MW}$, are shown in Figure 16. These projects represent a total of $208 \mathrm{MW}$ installed from 2003 to 2013 in 19 different states. The net energy generation amounts used to calculate the capacity factors are from U.S. Energy Information Administration (EIA)-923 and EIA-860 reports. 2014 reports were used for this analysis because 2014 is the most recent year for which a significant number of EIA-reported projects aligned with PNNL's distributed wind project records. The capacityweighted average capacity factor for the 2014 generation amounts of these 52 projects was $33 \%$.
The project-specific details that drive each project's estimated or reported energy generation amounts were not available for review for this report, but the amount of annual energy production that can be achieved by a distributed wind project is driven by many variables, primarily the project's available wind resource and siting (e.g., tower height, local obstructions, and other micrositing issues). Predictable and optimized performance allows for a higher capacity factor which in turn decreases a project's LCOE. To that end, DOE has solicited insight on the wind resource assessment practices from the distributed wind industry and published a report that summarizes the findings and prioritizes R\&D challenges that, if solved, will provide a high return on investment for the distributed wind industry (NREL 2016c).

Capacity factor can also be driven by turbine availability, i.e., the longer a turbine is not operating in a given year, the lower its overall annual capacity factor will be. $10 \mathrm{~kW}$ turbine models account for over half of the small wind sample size (i.e., 34 of the 65 projects). The estimated capacity factors for these $10 \mathrm{~kW}$ turbines, calculated using estimated energy generation amounts at the time of installation, range from $8 \%$ to $47 \%$. A total of 14 projects using turbines greater than $100 \mathrm{~kW}$ use $1.5 \mathrm{MW}$ turbines. The capacity factors for those projects, calculated using the energy generation amounts reported to the EIA, range from $14 \%$ to $55 \%$. These ranges underscore the idea that siting and availability issues influence capacity factors. Although the capacity factors shown in Figure 16 are based on actual reports, the small wind capacity factors in Figure 15 are estimates for future performance and are therefore not yet proven.

\footnotetext{
${ }^{18}$ The capacity factor calculation in this report uses the turbine's nominal, nameplate capacity, not its rated capacity. A turbine's rated capacity is its power output at $11 \mathrm{~m} / \mathrm{s}$ per AWEA Standard 9.1-2009.
} 


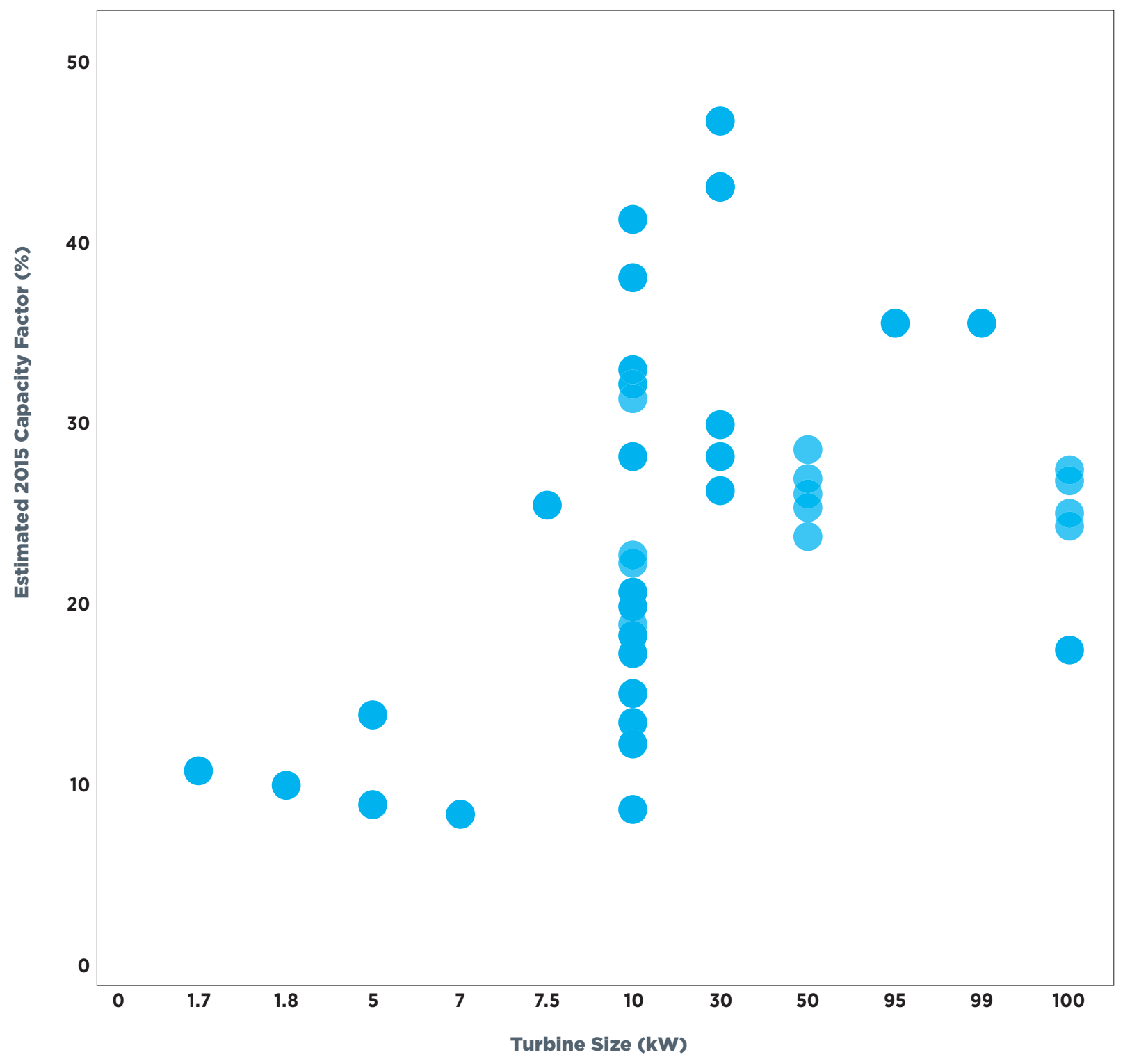

Figure 15. Estimated Capacity Factors for Selected 2015 Small Wind Projects 


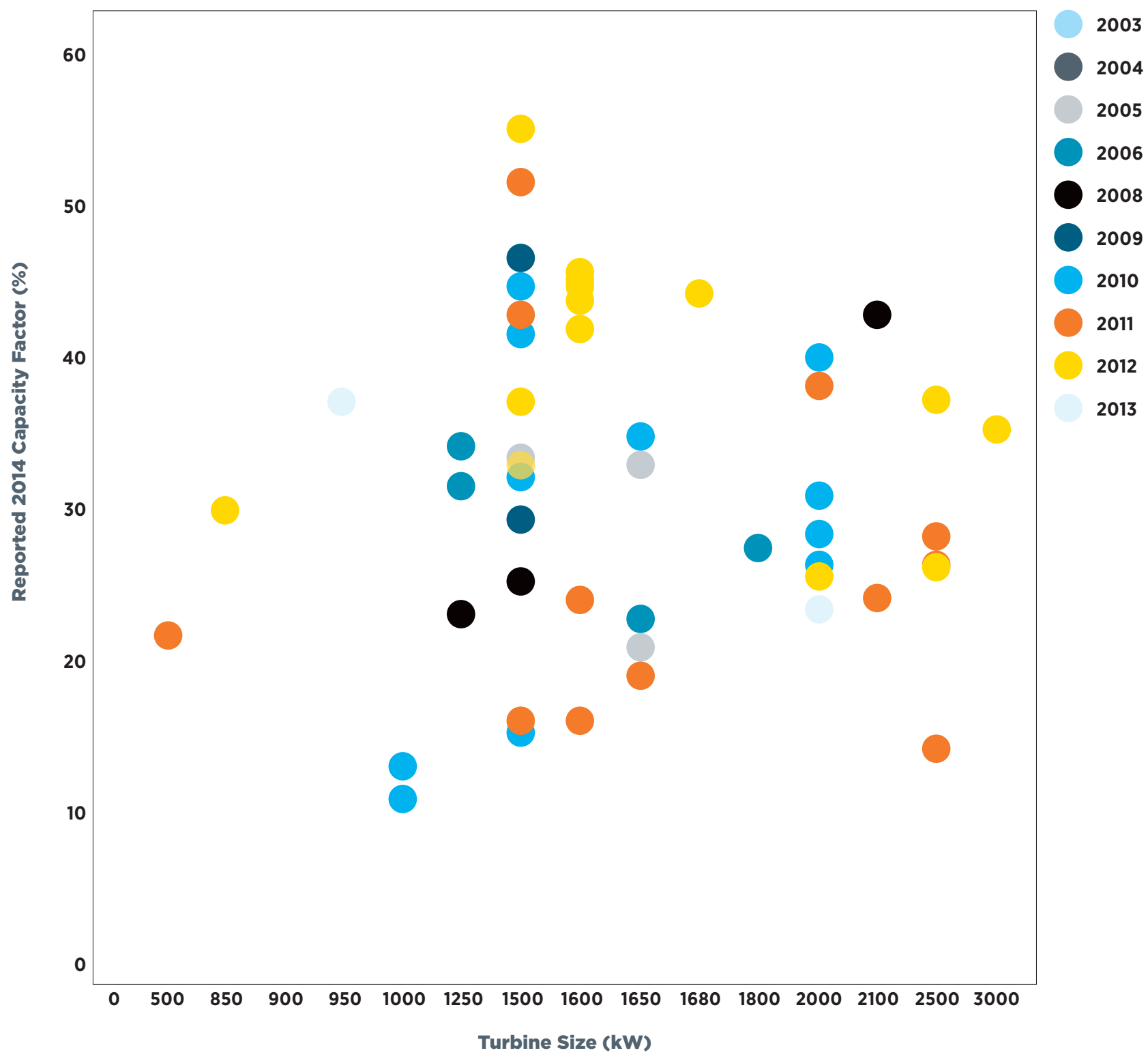

Figure 16. 2014 Reported Capacity Factors for Selected Distributed Wind Projects Using Turbines Greater than 100 kW 


\subsection{Levelized Cost of Energy}

The installed cost of the wind turbine and its performance, or capacity factor, are drivers of a project's LCOE.

LCOE is a function of a project's costs (installed and O\&M) divided by its annual energy production and is therefore expressed in $\$ / \mathrm{kWh}$ or $\phi / \mathrm{kWh}$. Appendix B describes the National Renewable Energy Laboratory's (NREL's) recommended method and assumptions used to calculate distributed wind LCOE (NREL 2013).

The LCOEs for a sample of 2015 small wind projects were calculated using records from USDA REAP, NYSERDA, and Alaska Energy Authority incentive programs. The sample includes 1.24 MW from 50 projects in Alaska, Minnesota, Nebraska, and New York and is limited to projects for which installed cost, incentive value, and estimated generation amount were available. O\&M cost estimates were based on the ranges presented in Section 5.3. The installed capital cost for each project was reduced by the project's incentive award for the LCOE calculation. The results of this analysis are shown in Figure 17.
The turbines represented in this sample range from 1.7 to $100 \mathrm{~kW}$ in size and, as discussed in Section 5.1, reflect a wide range of installed costs. The combined capacityweighted average LCOE for these 50 projects is $11 \notin / \mathrm{kWh}$, which is slightly lower than the $12 \phi / \mathrm{kWh}$ calculated for the sample of 2013 and 2014 projects used in last year's report.

Lower installed costs help lower the LCOE. One way to lower the installed cost for the system owner is through incentives. A rebate or grant that reduces the upfront cost for the wind turbine owner significantly decreases a project's LCOE. All of the projects in this sample received this type of incentive and, as a result, the average LCOE for these projects was reduced by $35 \%$.

According to the EIA, average residential retail electric rates range from 9.1 to $20.8 \phi / \mathrm{kWh}$ in the continental United States, with higher rates in Hawaii, Alaska, Puerto Rico, and the USVI as of March 2016 (EIA 2016). The average LCOE of $11 \phi / \mathrm{kWh}$ from these sample projects indicates that distributed wind has the potential to be cost-competitive with retail electricity rates.

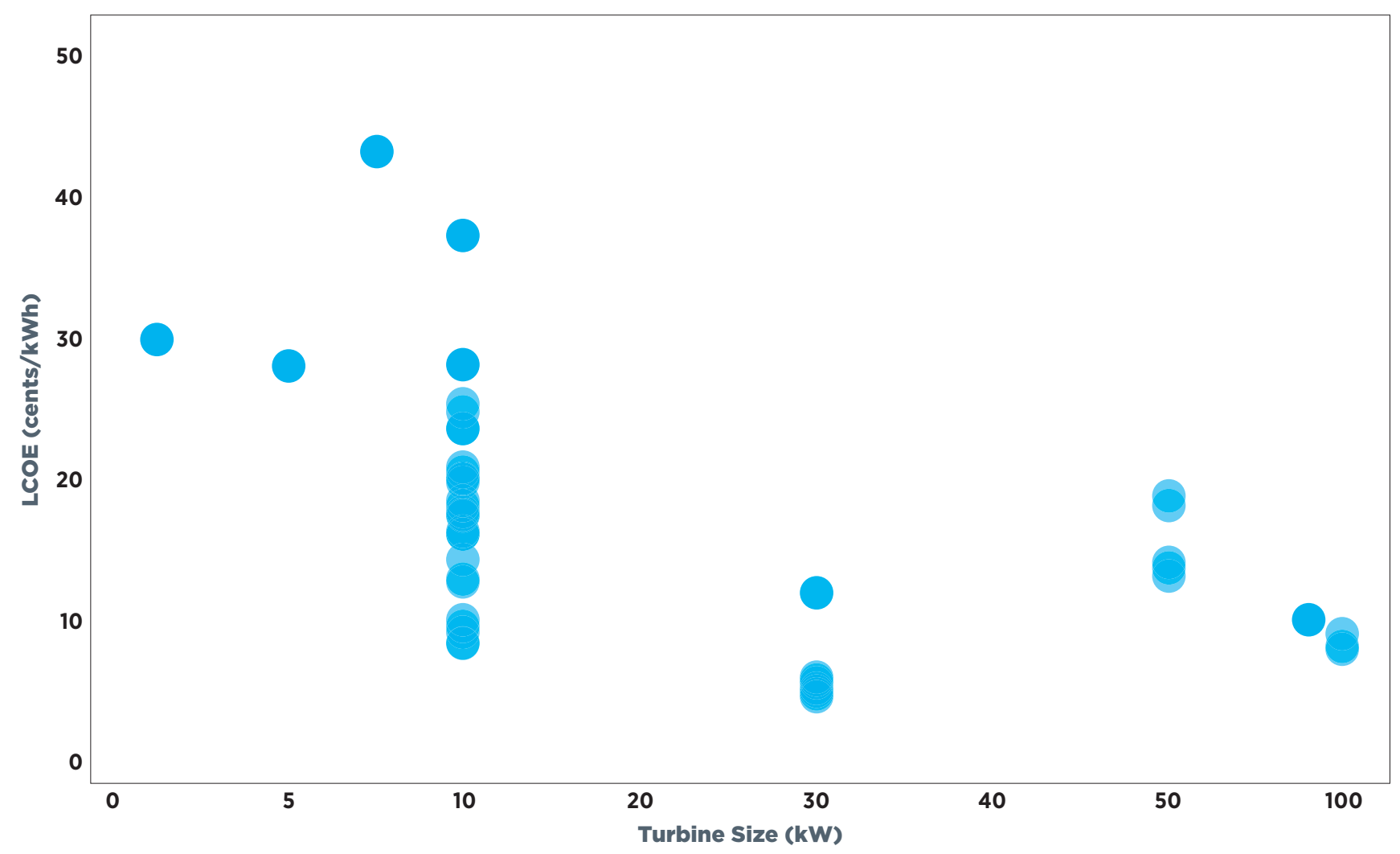

Figure 17. Levelized Costs of Energy (after Incentives) for Selected 2015 Small Wind Projects 
The LCOEs for a subsample of the projects analyzed in Figure 16 are shown in Figure 18. The subsample includes 26 projects totaling $127 \mathrm{MW}$ across ten states and is limited to projects for which installed cost, Section 1603 incentive value, and actual generation amount from EIA 2014 records were available. All costs are in 2014 dollars. O\&M cost estimates were based on the ranges presented in Section 5.3. The installed capital cost for each project is reduced by the project's Section 1603 cash grant award for the LCOE calculation.

The scatter in Figure 18 simply illustrates that, similar to small wind, projects installed in various years and locations using different turbine sizes achieve diverse LCOEs. The calculated LCOEs for these 26 projects range from just 0.6 to $7.1 \varnothing / \mathrm{kWh}$ with the capacity-weighted average LCOE at $3 \mathrm{c} / \mathrm{kWh}$. While these projects were installed in 2010, 2011, and 2012, their 2014 LCOEs correlate strongly with the national levelized average price of wind PPAs signed in 2014 of $2.35 \mathrm{k} / \mathrm{kWh}$ (Wiser and Bolinger 2015).

The relationship between the calculated LCOEs and the projected small wind capacity factors is shown in Figure 19. Figure 20 shows the calculated LCOEs and reported capacity factors for projects using wind turbines greater than $100 \mathrm{~kW}$. In general, the higher the capacity factor, the lower the LCOE. In Figure 19, the outlierwith a $25 \%$ capacity factor but a $43 \mathrm{c} / \mathrm{kWh}$ LCOE - is a project in Alaska, where installed costs are higher than in the continental United States, but because retail electric rates are also higher, the project remains cost effective.

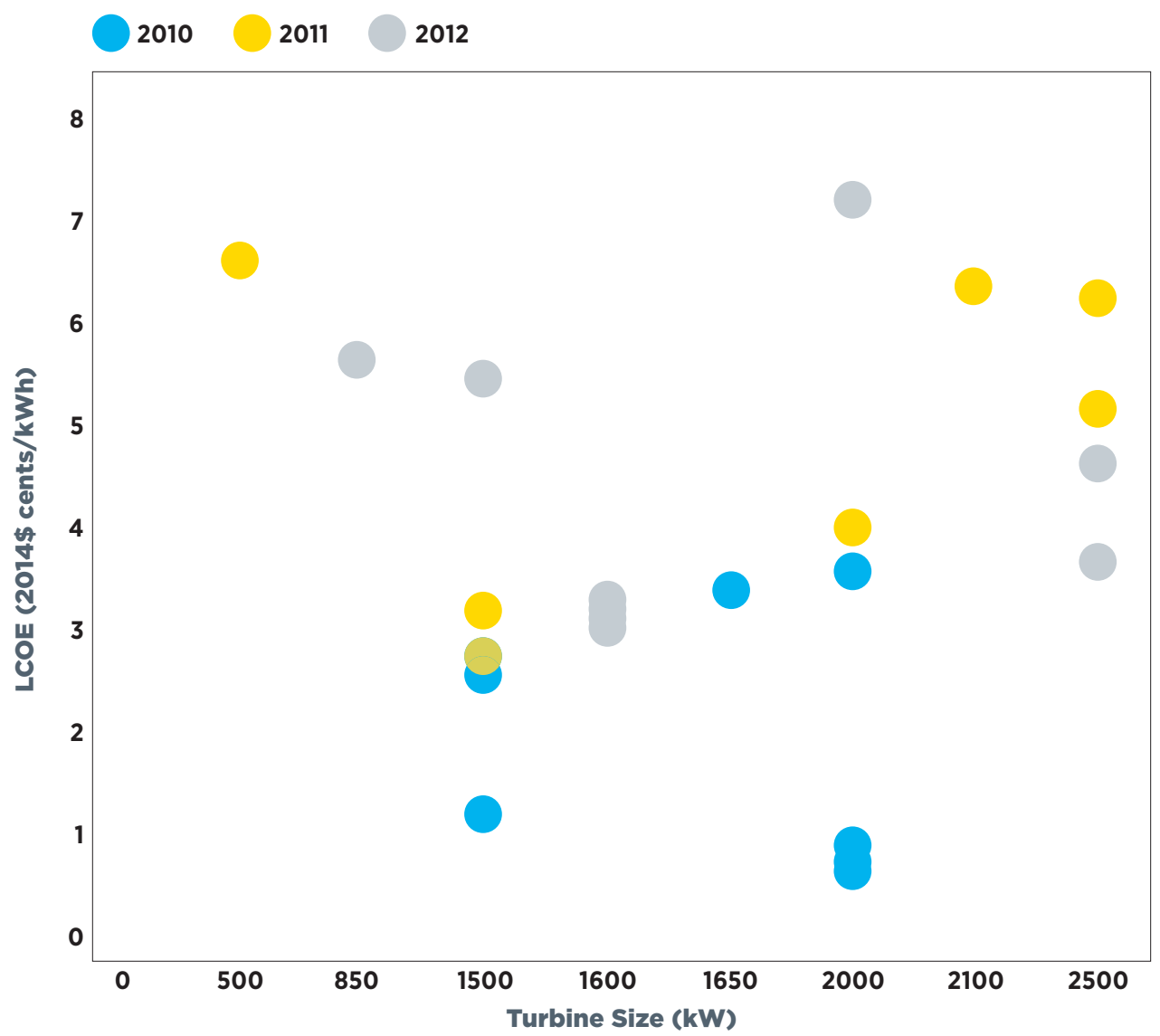

Figure 18. Levelized Costs of Energy (after Section 1603 Funding) for Selected Distributed Wind Projects Using Turbines Greater than 100 kW 


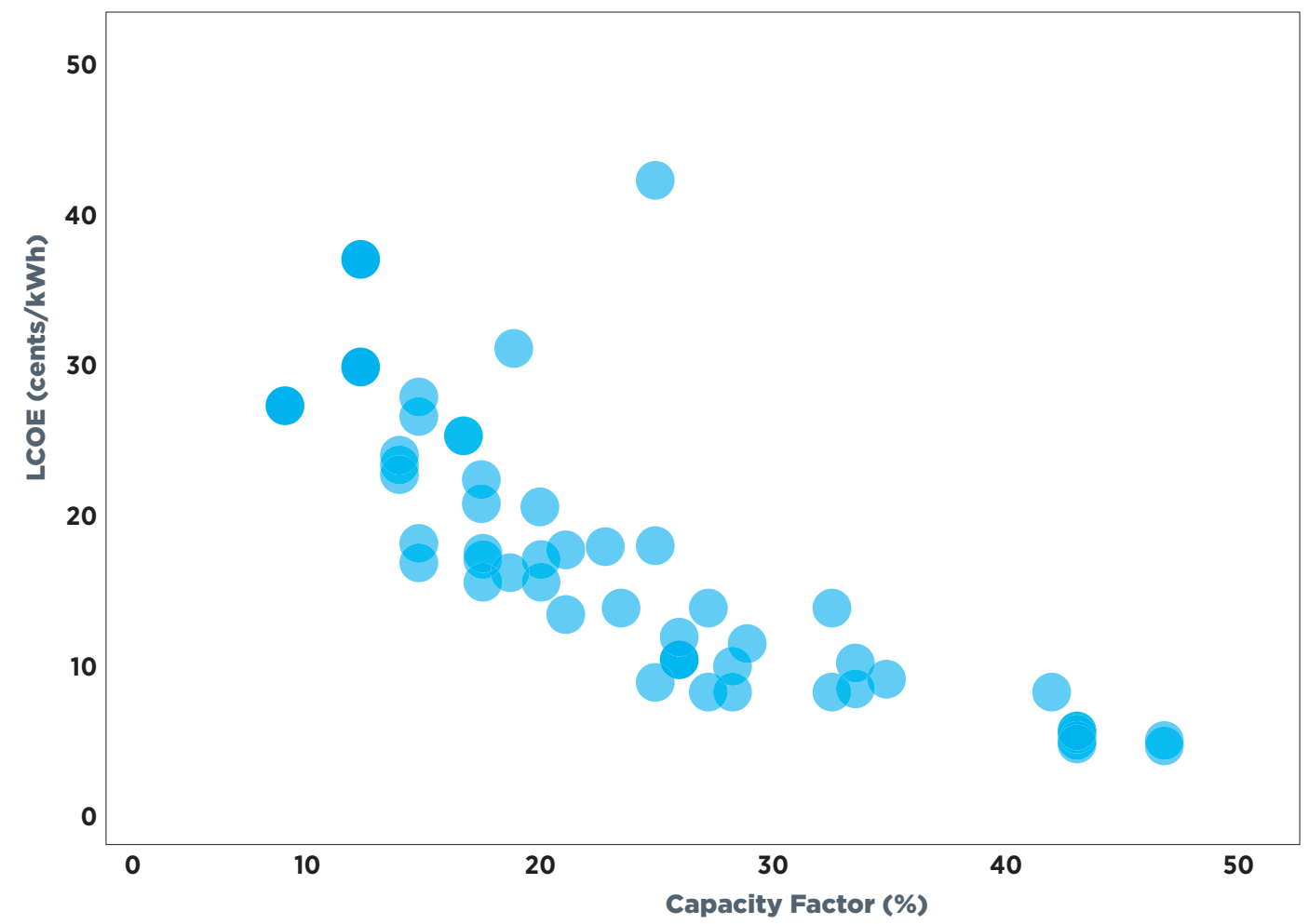

Figure 19. Levelized Costs of Energy and Capacity Factors for Selected Small Wind Projects

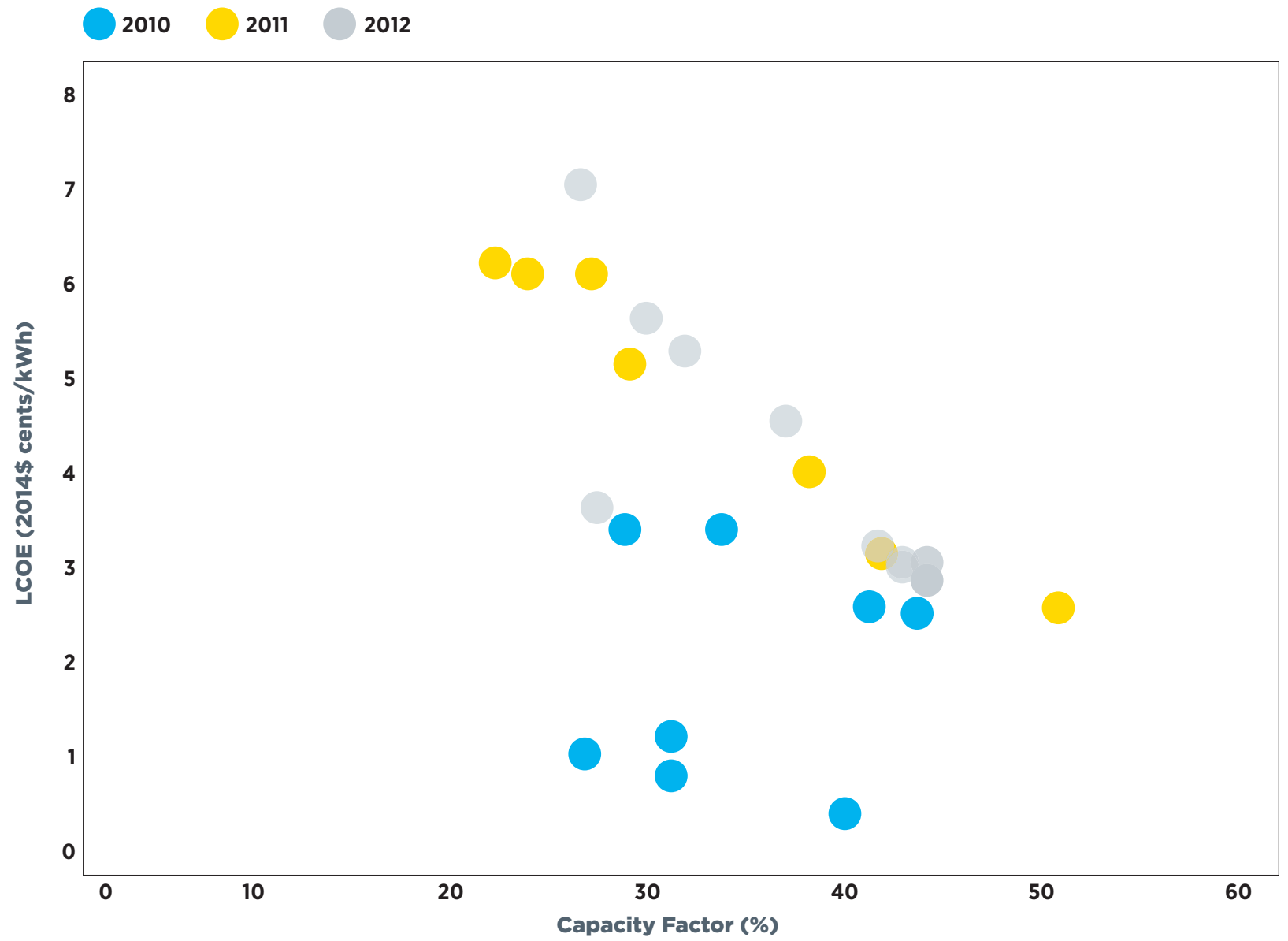

Figure 20. Levelized Costs of Energy and Capacity Factors for Selected Distributed Wind Projects Using Turbines Greater than 100 kW 


\subsection{Distributed Wind Markets}

Distributed wind projects range from a small turbine at an off-grid home to a large-scale turbine at a manufacturing facility. This section of the report looks at some of the details for the 2015 distributed wind sales and installations.

\subsection{Project Types}

This report considers six main project types for distributed wind: 1) residential, 2) agricultural, 3) industrial, 4) commercial, 5) government, and 6) institutional. Residential applications include remote cabins, private boats, rural homesteads, suburban homes, and multi-family dwellings. Agricultural applications include all types of farms, ranches, and agricultural operations. Industrial applications are facilities that manufacture goods or perform industrial processes (e.g., food processing plants, appliance manufacturing plants, and oil and gas operations). Examples of commercial applications include offices, car dealerships, retail spaces, restaurants, and telecommunications sites.

Government applications are projects for non-taxed entities such as cities, municipal facilities (e.g., water treatment plants), and military sites. Institutional applications are for entities that may also be non-taxed and mainly consist of schools, universities, and electric co-operatives and utilities.

Figure 21 shows the breakdown of project types by number of projects and by capacity. The figure illustrates how a small percentage of projects using large-scale turbines in industrial applications can account for much more capacity than many projects using small wind turbines in agricultural and residential applications.

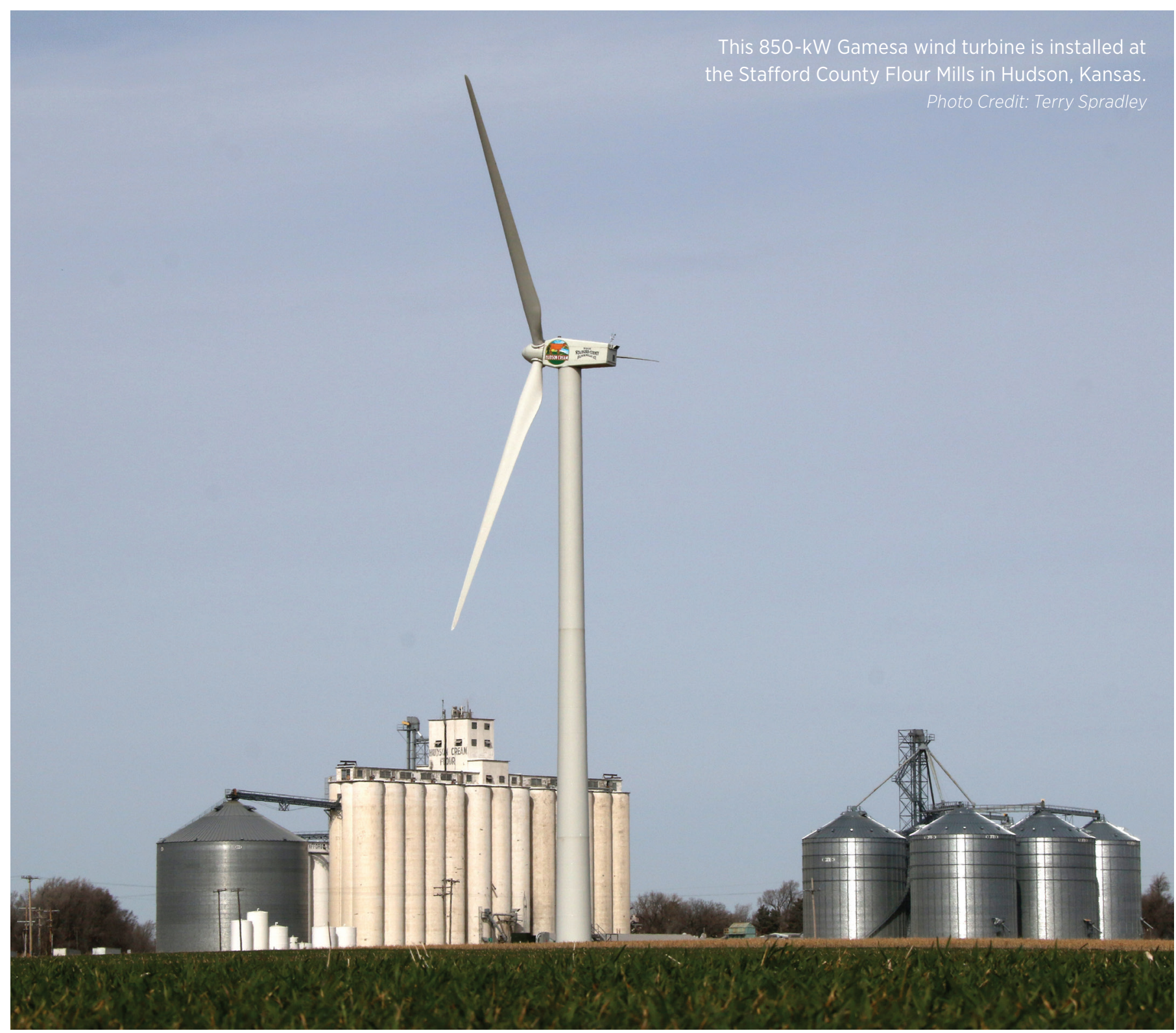




\section{Number of Projects}
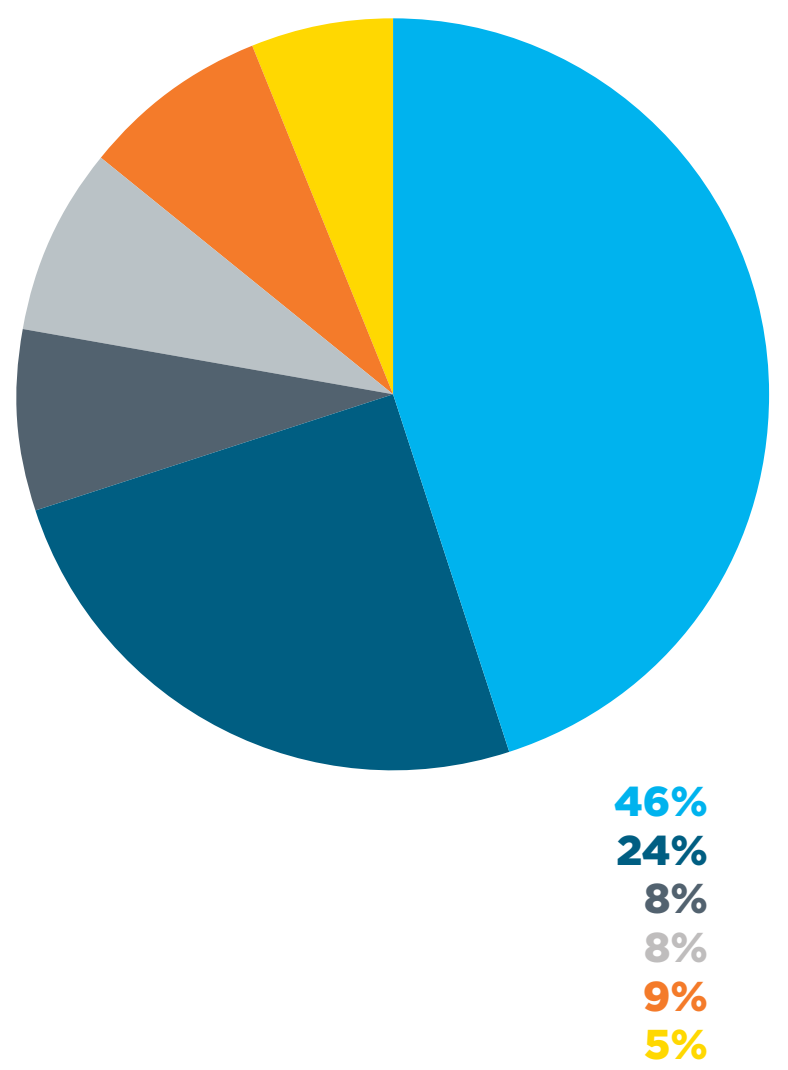

\section{Agricultural}

Residential

Government

Institutional

Commercial
Capacity of Projects

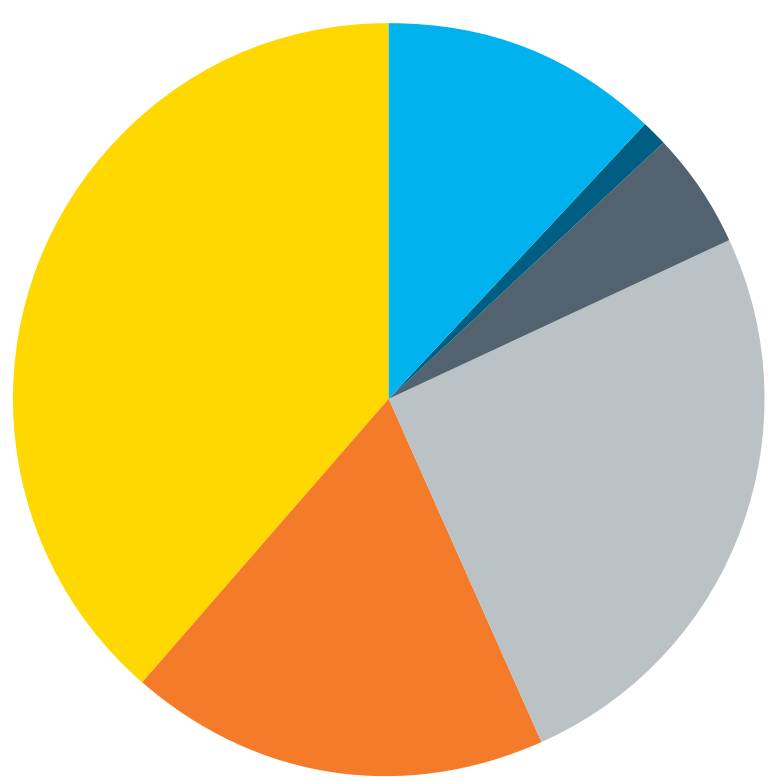

$12 \%$

$1 \%$

$5 \%$

$24 \%$

$20 \%$

$37 \%$

Figure 21. 2015 Distributed Wind Project Types by Capacity and by Project

\subsection{On-Site and Local Use}

In simple terms, a wind turbine or project is considered to provide distributed energy if it serves an on-site load (i.e., behind the meter, remote net-metered, or off-grid) or if it is connected to the local distribution grid to serve local loads (i.e., the generated energy is not sent past the local substation).

On a capacity basis, $49 \%$ of the documented 2015 distributed wind projects were connected to distribution lines serving local loads in Alaska, California, Connecticut, and Nebraska. The small wind turbines installed in California are assumed to be connected to the distribution grid. The other $51 \%$ served on-site loads, either as behind-the-meter, off-grid, micro-grid, or remote net meter applications across 26 states.

\subsection{Off-Grid and Grid-Tied}

Off-grid small wind turbine models continue to account for the bulk of wind turbine units deployed in U.S. distributed wind applications. An estimated 91\% of turbine units in 2015 distributed wind applications were deployed to charge batteries or power off-grid sites such as remote homes, oil and gas operations, telecommunications facilities, boats, rural water or electricity supply, and military sites. However, wind turbines connected to the distribution grid, or "grid-tied" applications, accounted for $99 \%$ of the annual distributed wind capacity (in terms of MW).

\subsection{Types of Wind Turbines and Towers}

In 2015, reported U.S. distributed wind projects encompassed 24 different wind turbine models ${ }^{19}$ ranging from $160 \mathrm{~W}$ to $2.85 \mathrm{MW}$ from 15 manufacturers and suppliers. In contrast, there were 34 different wind turbine models ranging from $160 \mathrm{~W}$ to $2 \mathrm{MW}$ from 21 manufacturers and suppliers documented in 2014, and 69 different models ranging from $100 \mathrm{~W}$ to $2 \mathrm{MW}$ from 28 manufacturers and suppliers documented in 2013.

Nine of the top ten models of all 2015 wind turbines deployed in U.S. distributed applications (on a unit basis) were from U.S.-based manufacturers.

\footnotetext{
${ }^{19}$ Turbine models can be newly manufactured, refurbished, or retrofitted. The definition of what constitutes a refurbished (or remanufactured or reconditioned) wind turbine varies. A refurbished turbine may be one that only had a few new parts added to the unit or simply had a change of hydraulic or transmission fluids before being resold. Alternatively, a refurbished turbine could have undergone an extensive remanufacturing process in which all of its parts were fully rebuilt. A retrofitted turbine is typically a newly manufactured turbine (i.e., nacelle, rotor, and generator) installed on an existing tower. For the purpose of federal ITC eligibility, a turbine must be new, where new is defined as having no more than $20 \%$ used parts. Therefore, some refurbished and retrofitted turbines qualify for the federal ITC.
} 
Of the 17 small wind turbine models deployed in the United States during 2015 reported by ten manufacturers, 4 have nominal capacity ratings less than $1 \mathrm{~kW}, 8$ are rated 1 to $10 \mathrm{~kW}$, and 5 are rated 11 to $100 \mathrm{~kW}$. The deployed capacities for these turbines are shown in Figure 22.

The number of wind turbine manufacturers supplying mid-size and large-scale turbines for distributed wind projects has contracted since 2012. In 2012, 27 manufacturers supplied 33 different mid-size and largescale turbine models for 69 projects. In 2013, there were six manufacturers with eight different turbine models for nine projects. 2014 was similar with six manufacturers providing nine turbine models for 12 projects. The contraction continued in 2015 with just five manufacturers providing seven turbine models for eight projects.

A wide range of tower designs and heights were sold for small wind turbine projects. In 2015, the most common, in order of prevalence, were self-supporting monopole, guyed monopole, guyed lattice, tilt-up monopole, and selfsupporting lattice.

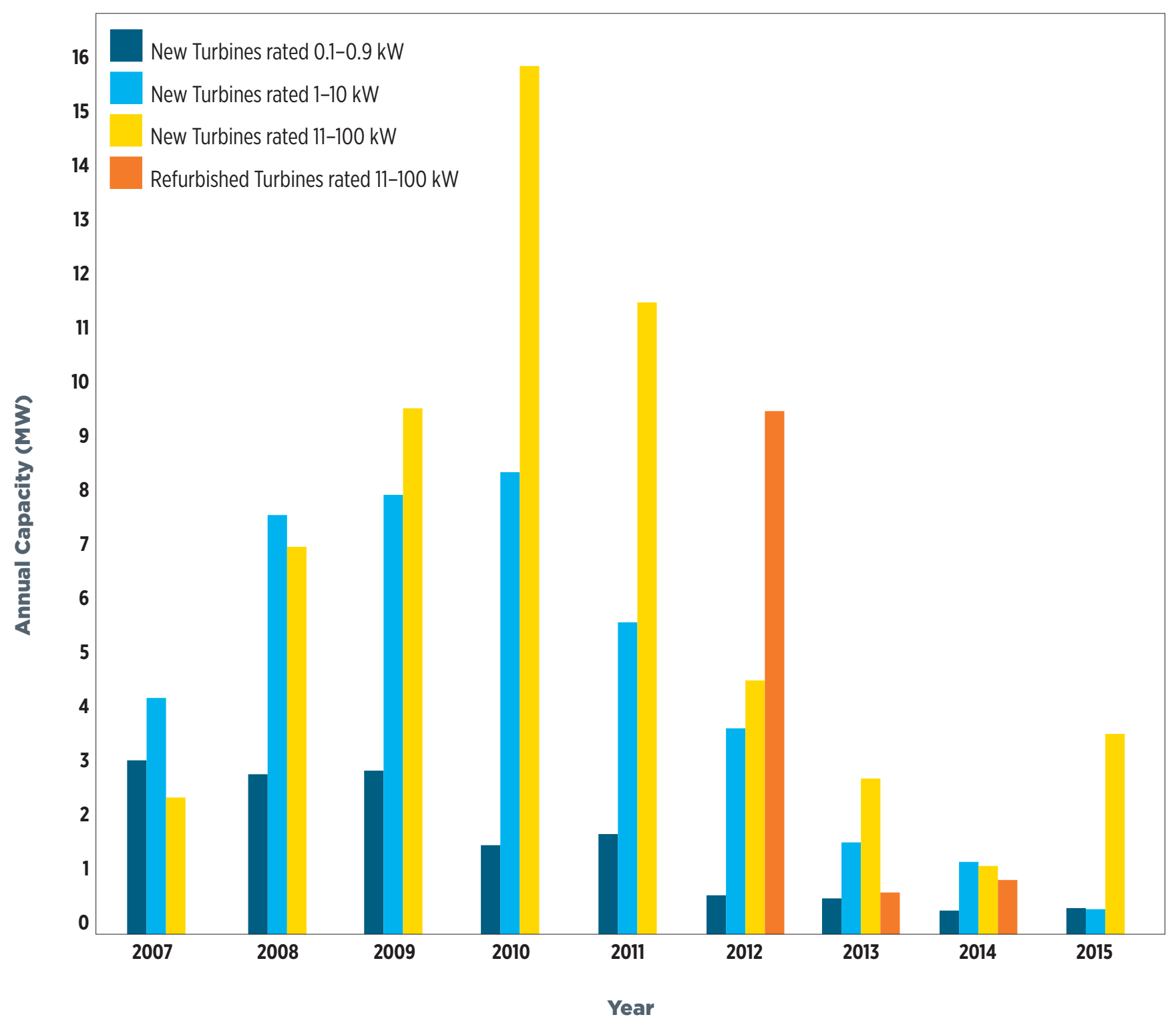

Figure 22. U.S. Small Wind Turbine Sales by Turbine Size 


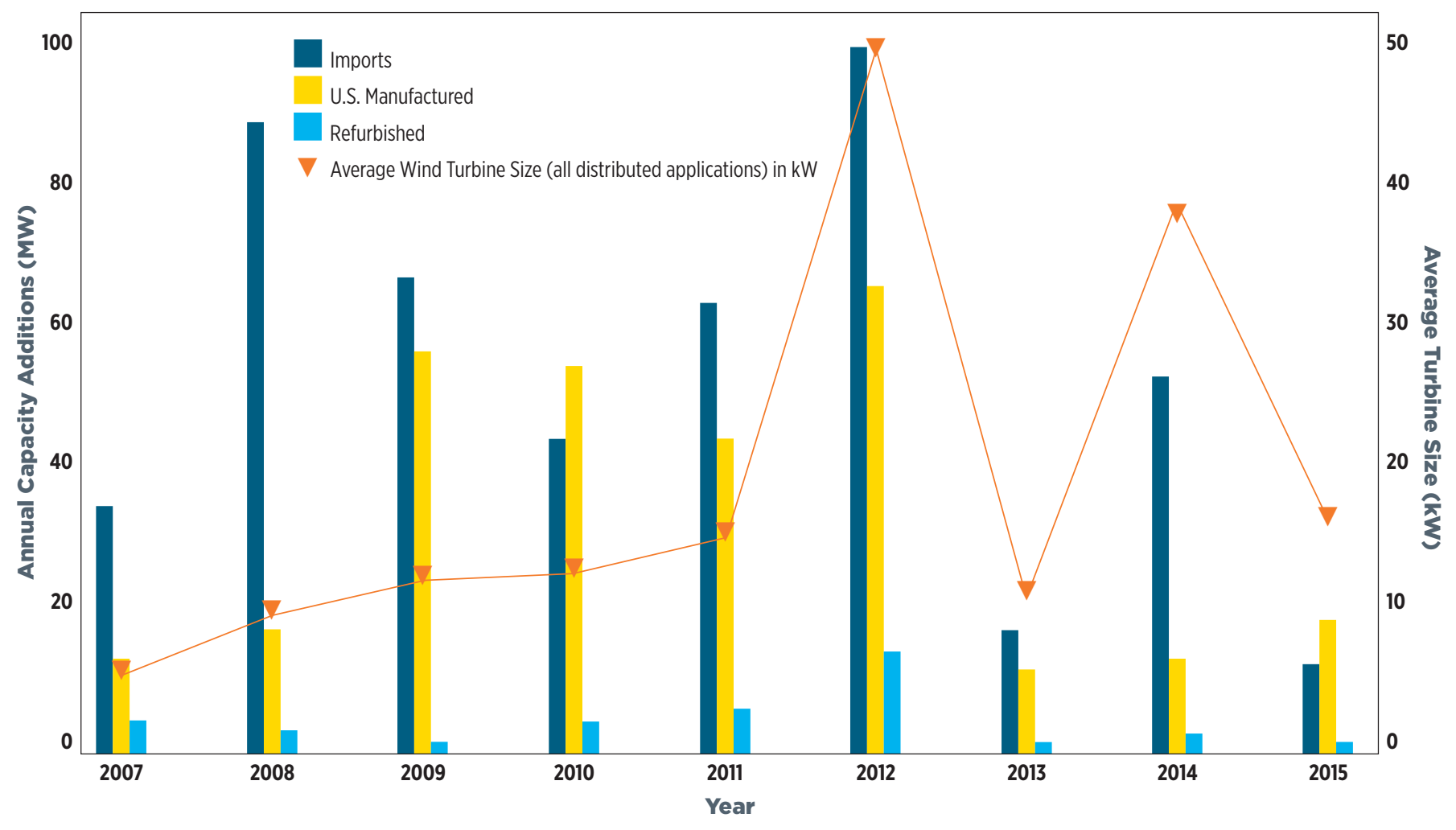

Figure 23. U.S. Distributed Wind Capacity by Type and Average Turbine Size

Reported turbine heights for small wind turbines sold in 2015 ranged from 10 to $46 \mathrm{~m}$. For turbines between $101 \mathrm{~kW}$ and $1 \mathrm{MW}$, turbine heights were 32,45 , and $55 \mathrm{~m}$. For turbines greater than $1 \mathrm{MW}$, four projects used $80 \mathrm{~m}$ towers and one project used a $98.3 \mathrm{~m}$ tower.

Consistent with past years, small VAWT models continued to represent a small portion of the small wind market in 2015 (i.e., about $2 \%$ of U.S. small wind capacity and about $4 \%$ of units in both 2014 and 2015).

In 2015, the average size of wind turbines in distributed applications was $16 \mathrm{~kW}$, down from $37 \mathrm{~kW}$ in 2014, up from $11 \mathrm{~kW}$ in 2013, and down from $47 \mathrm{~kW}$ in 2012. These fluctuations can be explained by the change in the most commonly used turbines in the given years. In 2012, many mid-size and large-scale turbines were deployed in distributed applications. But in 2013, off-grid wind turbines and smaller units represented a greater portion of projects. In 2014, the number of mid-size and large- scale turbines rebounded, increasing the average wind turbine size used in distributed applications. And in 2015, mid-size and large-scale turbine installations declined causing the average size to drop again. These trends are shown in Figure 23.

\subsection{Distributed Wind Turbine Units}

Wind turbines of all sizes in distributed wind applications accounted for $66 \%$ of the roughly 114,000 total wind turbines deployed in the United States (on a unit basis) since 2003 (Figure 24). However, a large number of units does not always equate to a large amount of capacity. For example, distributed wind accounted for less than $1 \%$ of all wind capacity installed in 2015, just over $1 \%$ in 2014, and just over $2 \%$ in 2013. Although distributed wind projects are not defined by project size, $90 \%$ of 2015 distributed wind projects were single-turbine projects. For context, wind turbines greater than $100 \mathrm{~kW}$ installed in wind farms (i.e., projects that do not meet the definition of distributed wind) are also shown in Figure 24 and Figure 25. 


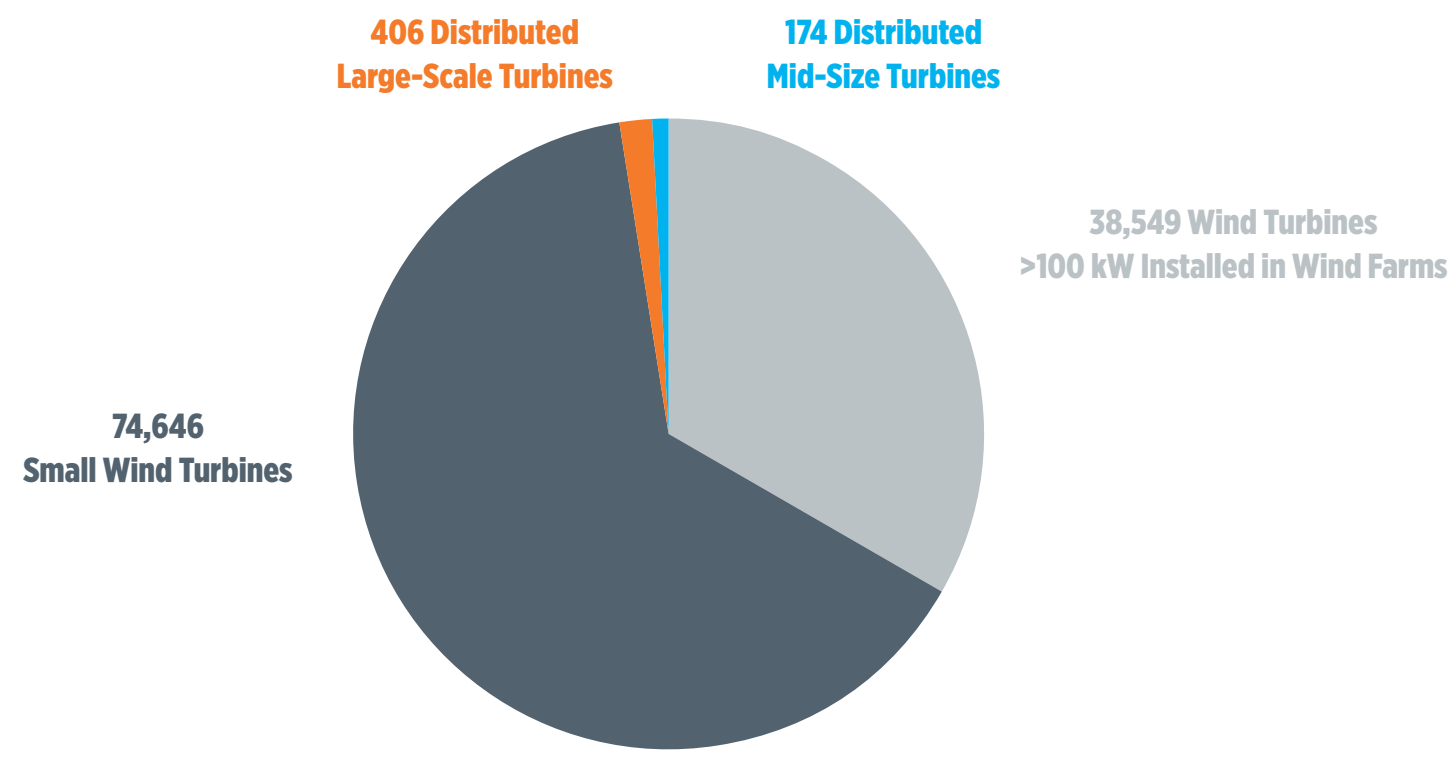

Figure 24. Cumulative Wind Farm and Distributed Wind Turbine Units, 2003-2015 ${ }^{20}$

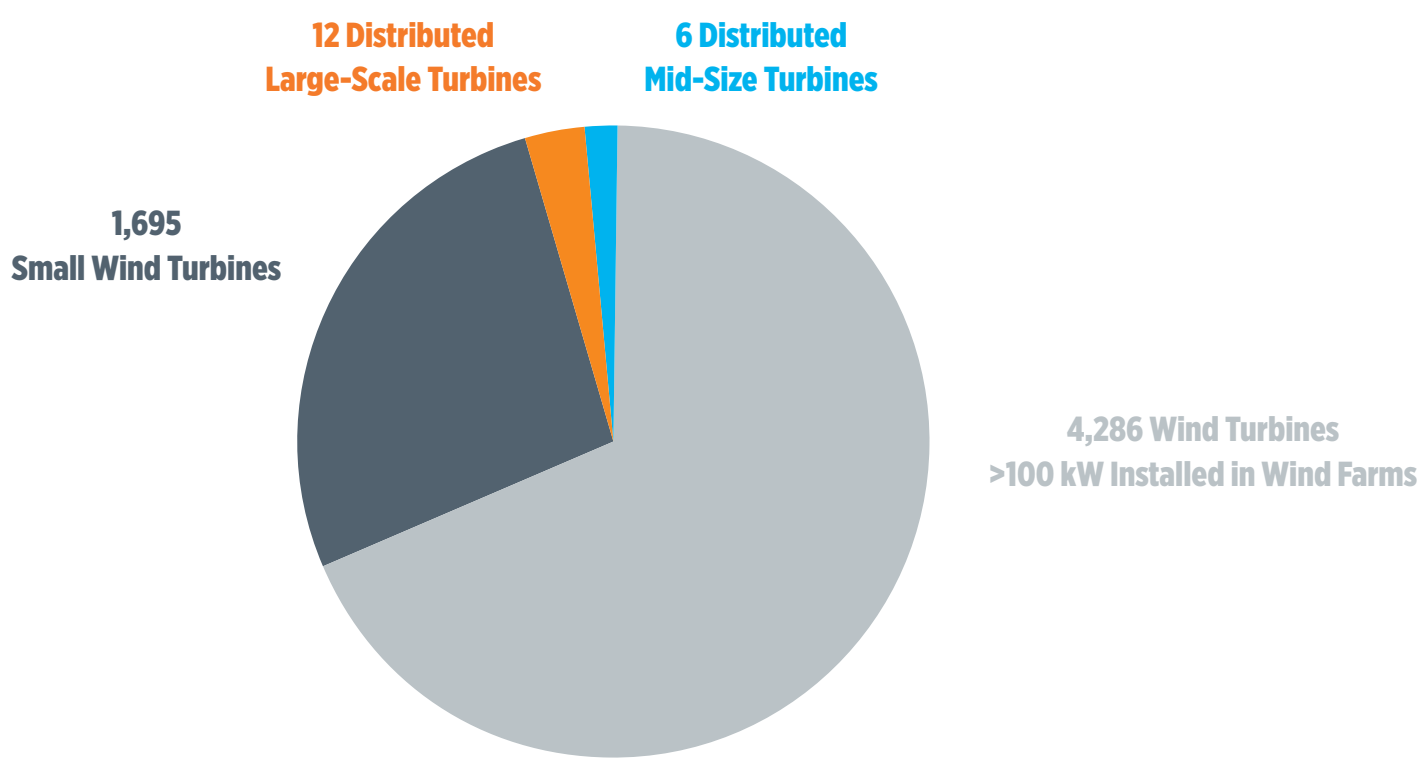

Figure 25. 2015 Wind Farm and Distributed Wind Turbine Units

\subsection{Corporate and Industrial Purchases}

Commercial and industrial ("C\&I"), non-utility purchases of wind energy have become a new source of demand driving the overall wind market. In many cases these C\&I purchases meet the definition of distributed wind. Universities, businesses, government agencies, and the manufacturing industry are using wind energy to power their operations. These purchases are through PPAs or direct investments in projects, both for on-site projects and projects near their facilities on the local distribution grid. C\&I projects accounted for $57 \%$ of the 2015 distributed wind installed capacity. For example, in 2015, One Energy LLC installed 7.5 MW of capacity to offset the power consumption of nearby Ball Corporation and Whirlpool Corporation facilities in Ohio; Method, the soap manufacturer, installed a $600 \mathrm{~kW}$ turbine at its manufacturing plant in Chicago; and an $850 \mathrm{~kW}$ turbine was installed at the Stafford County Flour Mills in Hudson, Kansas.

\footnotetext{
${ }^{20}$ The cumulative number of wind turbines greater than $100 \mathrm{~kW}$ installed in wind farms has been updated in this report to account for decommissioned wind turbines per AWEA records and a reporting error made in 2014
} 


\subsection{Manufacturing, Domestic Supply Chain, and Jobs}

U.S.-based small wind turbine manufacturers continued to favor U.S. supply chain vendors for most of their wind turbine components. Self-reported domestic content levels for 2015 ranged from $66 \%$ to $100 \%$. For parts not supplied within the United States, China was the primary source.

The U.S. distributed wind market is represented across the country. U.S. and international small wind manufacturers, O\&M providers, installers, and developers interviewed for this report support jobs in at least 23 states. Many manufacturers work with dealers and installers in most states.

One significant difference between small wind and solar PV in the United States is that U.S.-based small wind turbine manufacturers dominate the domestic small wind market while non-U.S.-based manufacturers dominate the solar PV market. Based on a survey of 28 solar panel manufacturers, 9 are U.S.-based companies with $30 \%$ of the U.S. market share and 19 are non-U.S.-based companies with $70 \%$ of the U.S. market share (Kann 2013).
The Sustainable Manufacturing, Advanced Research \& Technology (SMART) Wind Consortium was formed to aid distributed wind industry growth and adoption of innovative manufacturing techniques. As a final product, SMART Wind Consortium leaders developed a consensus-based, shared-vision Distributed Wind Technology Roadmap that captures feedback from industry stakeholders to help move the U.S. distributed wind industry into a more globally competitive stance.

The SMART Wind Consortium included 14 distributed wind original equipment manufacturers (OEMs) based in ten states and Canada. According to the SMART Wind Roadmap (DWEA 2016), these OEMs identified 29 toptier and dominant supply chain vendors in the United States for mechanical parts, electrical parts, composites, and support structures located in 12 states, with a strong presence of mechanical parts vendors in the northeastern United States.

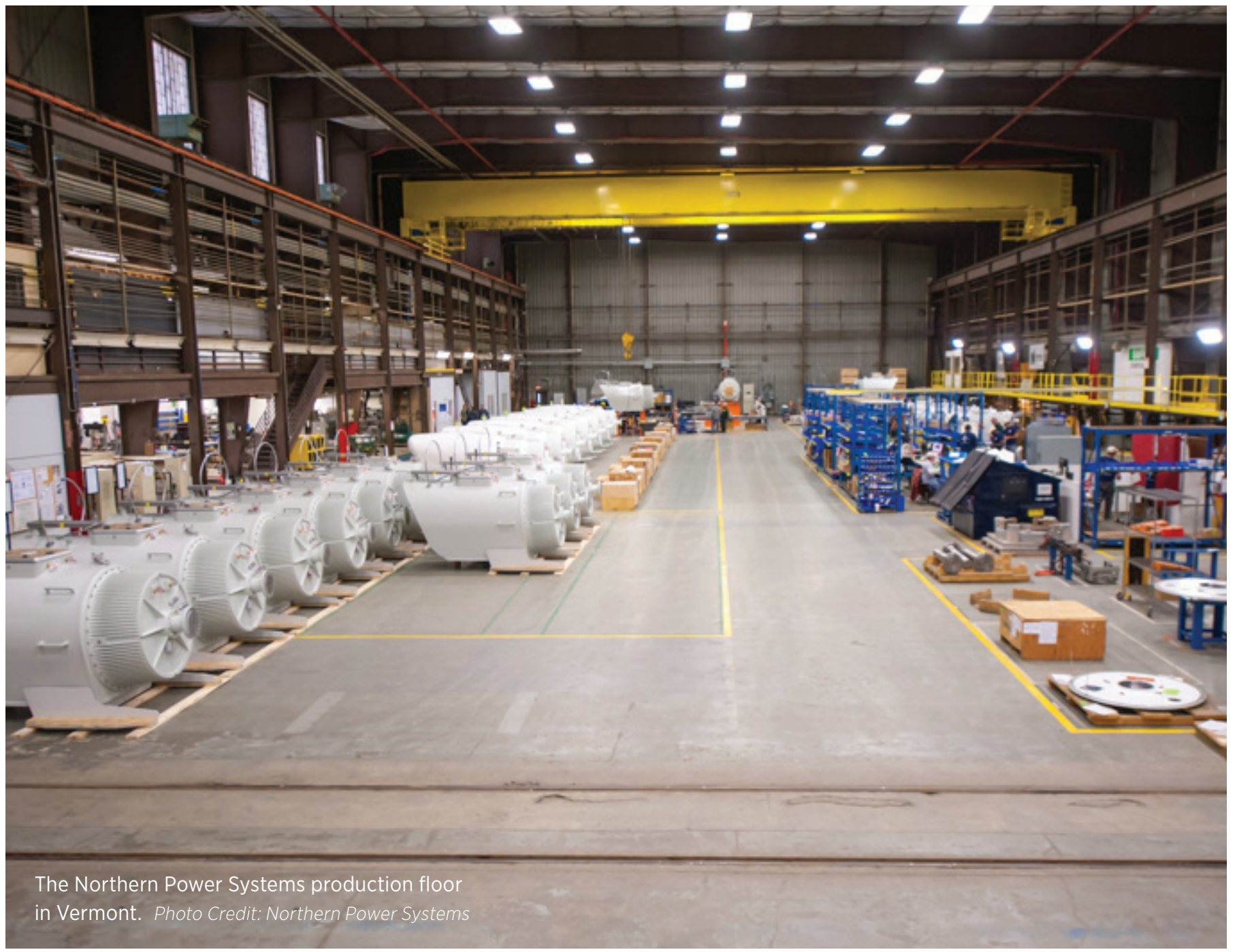




\subsection{Outlook}

The U.S. distributed wind market has reached a plateau. U.S. small wind sales and mid-size installations have been relatively flat for the past three years. With the exception of two large projects using turbines greater than $1 \mathrm{MW}$ in 2014 that accounted for almost $35 \mathrm{MW}$, the large-scale sector has also been flat in recent years.

The impact of the recent ITC (and PTC) changes will be felt in the coming years. The pending expiration of the Residential Renewable Energy Tax Credit for small wind at the end of 2016 could create a sense of urgency, pushing sales up in 2016, but then result in another boom/bust cycle with lower sales in 2017 and beyond. How or if the small wind certification requirement has affected the market will be more clear after 2016. Manufacturers with pending certification applications may have to consider the value of continuing to pursue certification in light of the residential ITC's planned expiration for small wind.

A general downward trend in state and federal incentive funding levels and programs; the relatively low cost of electricity, driven by low natural gas prices; and competition from other technologies, such as solar photovoltaics, are leading to a further market contraction on the supplier side. However, wind lease programs, first adopted by the solar PV industry, are an emerging market driver as more companies adopt this business model.

At the same time, U.S. manufacturers of small wind turbines have posted another record year of exports in 2015, doubling capacity sent abroad to important markets, such as Italy, the United Kingdom, and Japan. This trend of strong exports is expected to continue.

The global outlook for small wind has been researched by multiple organizations. The World Wind Energy Association, Navigant Research, and GlobalData have published projections for the global small wind market based on different compound annual growth rate (CAGR) and existing global capacity assumptions as shown in Table 6 (Gsänger and Pitteloud 2016; Gauntlett and Asmus 2014; GlobalData 2015). Navigant Research includes 101 through $500 \mathrm{~kW}$ wind turbines in its projection and does not separate these turbines from small wind.

The projections largely agree that roughly $300 \mathrm{MW}$ of global small wind capacity will be installed in 2020. According to the World Wind Energy Association, $82 \mathrm{MW}$ of capacity was installed in 2014 (Gsänger and Pitteloud 2016). Based on the numbers reported by countries surveyed for this report, at least $122 \mathrm{MW}$ of small wind was installed in 2014. Based on these 2014 capacity values, in order to achieve an installed capacity of $300 \mathrm{MW}$ in 2020, global growth rates would have to exceed 16\% for 2015 through 2020 , which is mostly in line with the CAGRs shown in Table 7.

However, given the stagnant Chinese market, the modest growth in the United States over the past three years, and the reduced funding levels for the United Kingdom's FIT, achieving $300 \mathrm{MW}$ of annual additions by 2020 appears to be a highly ambitious target - considering these three countries are the major global markets that have driven past growth in global installations.

Table 6. Global Small ${ }^{21}$ Wind Projections

$\begin{array}{lccc} & \begin{array}{c}\text { World Wind Energy } \\ \text { Association }\end{array} & \begin{array}{c}\text { Navigant } \\ \text { Research }\end{array} & \text { GlobalDatac }^{\text {a }} \\ \begin{array}{l}\text { Annual Global Capacity Addition } \\ \text { Projection for } 2020 \text { (MW) }\end{array} & 300 & 330 & 265\end{array}$

\footnotetext{
${ }^{a}$ CAGR of 11\% for 2015-2016 and 20\% for 2016-2020; March 2016 publication date

${ }^{b}$ CAGR of 9.7\% for 2014-2023; December 2014 publication date

${ }^{c}$ CAGR of $16.4 \%$ for 2015-2025; December 2015 publication date
}

\footnotetext{
${ }^{21}$ Navigant's reporting and projections are for wind turbines up through $500 \mathrm{~kW}$ in size.
} 


\subsection{References}

ASSIEME (Associazone Italiana Energie Mini Eolica). 2014. Report Mini Eolico Italia 06/2014. Rome: ASSIEME. http:// www.assieme.eu/doc/report_mini_eolico_italia_062014.pdf.

ASSIEME (Associazone Italiana Energie Mini Eolica). 2016. Preview of 2015 Small Wind Report. Provided by Alessandro Giubilo, President of ASSIEME, via email to author on March 25, 2016.

AWEA (American Wind Energy Association). 2010. AWEA Small Wind Turbine Global Market Study Year Ending 2009. Washington, DC: AWEA.

AWEA (American Wind Energy Association). 2012. 2011

U.S. Small Wind Turbine Market Report Year Ending 2011. Washington, DC: AWEA.

AWEA (American Wind Energy Association). 2016. U.S. Wind Industry Annual Market Report Year Ending 2015. Washington, DC: AWEA.

Barbose, G. and N. Darghouth. 2015. "Tracking the Sun VIII, The Installed Price of Residential and Non-Residential Photovoltaic Systems in the United States." https:/emp.lbl. gov/sites/all/files/lbnl-188238_2.pdf.

CWEEA (Chinese Wind Energy Equipment Association). 2016. Annual statistics. Provided by Charlie Duo, Senior Advisor to the China Wind Energy Equipment Association, via email to the author on January 28, 2016.

DECC (Department of Energy and Climate Change). 2015a. Consultation on a review of the Feed-in Tariffs scheme. London: DECC. https://www.gov.uk/government/uploads/ system/uploads/attachment_data/file/469476/Consultation on_a_Review_of_feed-in_tariff_scheme.pdf.

DECC (Department of Energy and Climate Change). 2015b. Review of the Feed-in Tariffs Scheme. London: DECC. https:/www.gov.uk/government/uploads/system/uploads/ attachment_data/file/487300/fits_review_govt_response_ final.pdf.

DWEA (Distributed Wind Energy Association). 2015a. DWEA Distributed Wind Vision - 2015-2030, Strategies to reach 30 GW of "behind-the-meter" wind generation by 2030. Durango: DWEA. http://distributedwind.org/wp-content/ uploads/2012/08/DWEA-Distributed-Wind-Vision.pdf.

DWEA (Distributed Wind Energy Association). 2015b. IRS will require small wind turbines be certified. Durango: DWEA. http://distributedwind.org/irs-will-require-small-windturbines-be-certified/.
DWEA (Distributed Wind Energy Association). 2016. SMART Wind Roadmap: A Consensus-Based, SharedVision Sustainable Manufacturing, Advanced Research \& Technology Action Plan for Distributed Wind. Washington, DC: U.S. Department of Commerce. http://distributedwind. org/wp-content/uploads/2016/05/smart-wind-roadmap.pdf.

EC (European Commission). 2013. Italy's Second Progress Report under Directive2009/28/EC, p. 4. Brussels: EC. http:// www.eurobserv-er.org/pdf/res-policy/eurobserver-res-policyreport-article-22-italy-report-en.pdf.

EERE (U.S. Department of Energy, Office of Energy Efficiency and Renewable Energy). 2014. "Colorado 30-m Wind Map." Last modified May 1, 2014. http://apps2.eere.energy.gov/ wind/windexchange/windmaps/residential_scale_states. asp? stateab $=$ co.

EIA (U.S. Energy Information Administration). 2016. "Electric Power Monthly, Table 5.6.A, Average Retail Price of Electricity to Ultimate Customers by End-Use Sector, by State, March 2016 and 2015 (Cents per Kilowatthour)." Accessed June 2016. https://www.eia.gov/electricity/monthly/ epm_table_grapher.cfm?t=epmt_5_6_a.

EurObserv'ER. 2015. Country Policy Profile Italy. Paris. http:// www.eurobserv-er.org/pdf/res-policy/EurObservER-RESPolicy-Report-Country-Profile-2015-12-Italy.pdf.

Freeing the Grid. 2015. “Glossary.” Accessed March 2016. http://freeingthegrid.org/\#education-center/glossary/.

Gauntlett, D., and P. Asmus. 2014. Small and Medium Wind Power. Boulder, CO: Navigant Consulting, Inc.

GlobalData. 2015. Small Wind Turbine (up to $100 \mathrm{~kW}$ ) Market, Update 2015 - Market Size, Average Price, Competitive Landscape, Regulations and Key Country Analysis to 2025. Manchester, United Kingdom: GlobalData.

Gsänger, S., and J. Pitteloud. 2014. Small Wind World Report 2014 Update. Bonn, Germany: World Wind Energy Association.

Gsänger, S., and J. Pitteloud. 2016. Small Wind World Report 2016 Summary. Bonn, Germany: World Wind Energy Association.

HikaruWindLab. 2016. Small Wind Turbine Data under METI FIT. Provided by Hikaru Matsumiya, HikaruWindLab, via email to author on February, 2, 2016. 
IREC (Interstate Renewable Energy Council). 2016. "Certified Small Wind Turbines, Ratings of Certified Small Wind Turbine Models - May 2016." Accessed May 27, 2016. http://www. irecusa.org/credentialing/certified-small-wind-turbines/.

IRS (U.S. Internal Revenue Service). 2015. Property Qualifying for the Energy Credit under Section 48, Notice 2015-4. Washington, DC: IRS. http://www.irs.gov/pub/irs-drop/n-15-04.pdf.

IRS (U.S. Internal Revenue Service). 2016. Beginning of Construction for Sections 45 and 48, Notice 2016-31. Washington, DC: IRS. https://www.irs.gov/pub/irsdrop/n-16-31.pdf.

Jakovlev, P. 2016. "Northern Power Systems Announces Lease Facility for Distributed Generation Wind Financing." The NPS Blog, January 13. http://www.northernpower.com/npswind-power-lease/.

Kann, S. 2013. "U.S. Residential Solar PV Financing: The Vendor, Installer and Financier Landscape, 2013-2016." GTM Research. Last Modified February 2013. http://www. greentechmedia.com/research/report/u.s.-residential-solar-pvfinancing.

King, H. 2016. "REE - Rare Earth Elements and their Uses." Geology.com. Accessed June 2016. http://geology.com/ articles/rare-earth-elements/.

Magnier, M. 2016. “China's Economic Growth in 2015 Is Slowest in 25 Years." The Wall Street Journal, January 19. http://www.wsj.com/articles/china-economic-growth-slowsto-6-9-on-year-in-2015-1453169398.

METI (Ministry of Economy, Trade and Industry). 2015a. Longterm Energy Supply and Demand Outlook. http://www.meti. go.jp/english/press/2015/pdf/0716_01a.pdf

METI (Ministry of Economy, Trade and Industry). 2015b. Settlement of FY2015 Purchase Prices and FY2015 Surcharge Rates under the Feed-in Tariff Scheme for Renewable Energy. Accessed March 3, 2016. http://www.meti.go.jp/english/ press/2015/0319_01.html.

Milder, F. 2016. "Renewable energy tax credits: IRS provides new guidance for 'begun construction' test following 2015 tax legislation.” Accessed May 9, 2016. http://www. nixonpeabody.com/IRS-issues-new-guidance-for-renewableenergy-tax-credits.

NREL (National Renewable Energy Laboratory). 2016a. Texas Contributors. The Open PV Project. Accessed March 2016 at https://openpv.nrel.gov/search?state $=$ TX\&zipcode $=$.
NREL (National Renewable Energy Laboratory). 2016b. Deployment of Wind Turbines in the Built Environment: Risks, Lessons and Recommended Practices. Boulder, CO: NREL. http:/www.nrel.gov/docs/fy16osti/65622.pdf.

NREL (National Renewable Energy Laboratory). 2016c. Distributed Wind Resource Assessment: State of the Industry. Boulder, CO: NREL. http://www.nrel.gov/docs/ fy16osti/66419.pdf.

NREL (National Renewable Energy Laboratory). 2013. Figure of Merit - Cost of Energy for Distributed Wind $\left(200 \mathrm{~m}^{2}\right.$ to $1000 \mathrm{~m}^{2}$ ). Boulder, CO: NREL.

OFGEM (Office of Gas and Electricity Markets). 2016. Feed-in Tariff Generation \& Export Payment Rate Table-08 February -31 March 2016. London: OFGEM. https://www.ofgem.gov. uk/system/files/docs/2016/02/feed-in_tariff_generation_and export tables_08.02.2016_-_31.03.2016.pdf.

SEC (U.S. Securities and Exchange Commission). 2015. "Form 10-K for Xzeres Corp." Last modified June 24, 2015. https:// biz.yahoo.com/e/150624/xpwr10-k.html.

SEIA (Solar Energy Industries Association). 2015. "Solar Market Insight Q3 2015." https://www.seia.org/researchresources/solar-market-insight-2015-q3.

Stock, Y. 2016. "Decrease of renewable energy feed-in tariffs in China." Chinese European Energy News, January 11. http://ceenews.info/en/decrease-of-renewable-energy-feed-intariffs-in-china/.

Terna. 2014. Dati statistici sull'energia elettrica in Italia - 2014. Rome: Terna. http://download.terna.it/ terna/0000/0607/85.PDF.

Treasury (U.S. Department of Treasury). 2016. "List of Awards: Section 1603 - Payments for Specified Renewable Energy Property in Lieu of Tax Credits Awardees as of January 1, 2016." Last modified January 1, 2016. http://www.treasury. gov/initiatives/recovery/Pages/1603.aspx.

United Wind. 2016. "Forum Equity Partners and United Wind Announce \$200M Investment for Distributed Wind Projects." Last modified January 6, 2016. http://unitedwind.com/ forum-equity-partners-and-united-wind-announce-200minvestment-for-distributed-wind-projects-2/. 
USDA (United States Department of Agriculture). 2016.

FY2016 Budget Summary and Annual Performance Plan. Washington, DC: USDA. http://www.obpa.usda.gov/ budsum/fyl6budsum.pdf.

USDA (United States Department of Agriculture). 2014. 2014 Farm Bill Highlights. Washington, DC: USDA. https://www. usda.gov/documents/usda-2014-farm-bill-highlights.pdf.

Vermont Business Magazine. 2016. "The fix is in, $S 260$ renewable energy bill signed into law." June 13, 2016. http:// vermontbiz.com/news/june/fix-s260-renewable-energy-billsigned-law.
Vermont PSB (Public Service Board State of Vermont). 2014. "Investigation Into the Potential Establishment of Sound Standards (Docket 8167)." Accessed May 2016. http://psb. vermont.gov/docketsandprojects/electric/8167.

Wiser, R. and M. Bolinger. 2015. 2014 Wind Technologies Market Report. Berkeley, CA: Lawrence Berkeley National Laboratory. http://energy.gov/sites/prod/files/2015/08/ f25/2014-Wind-Technologies-Market-Report-8.7.pdf.

Xzeres. 2014. "New Lease Financing Eliminates the Upfront Costs for Small Wind Turbine Market." February 26, 2014. http://www.xzeres.com/news/xzeres-launches-powerleasefinancing-program/. 


\section{APPENDIX A WIND TURBINE MANUFACTURERS AND SUPPLIERS}

This report reflects 2015 sales and installations from the manufacturers and suppliers listed below. Others who provided information and/or who are non-U.S.-based and only had nonU.S. sales are recognized in the Acknowledgments section.

\begin{tabular}{|c|c|c|}
\hline Manufacturer & Model Names & Headquarters \\
\hline \multicolumn{3}{|c|}{ Small Wind Turbines (up through $100 \mathrm{~kW}$ ) } \\
\hline Bergey Windpower & XL.1, Excel 6, Excel R, Excel 10 & Oklahoma \\
\hline Dakota Turbines & DT-30 & North Dakota \\
\hline Gaia-Wind & Gaia-Wind 133 & United Kingdom \\
\hline Northern Power Systems & NPS 100C-24, NPS 60 & Vermont \\
\hline Ogin & Ogin & Massachusetts \\
\hline Pika Energy & T701 & Maine \\
\hline Primus Wind Power & AIR 30/AIR X Marine, AIR 40/AIR Breeze & Colorado \\
\hline Renewtech & WT100 & Minnesota \\
\hline Sonkyo Energy & Windspot & Spain \\
\hline UGE International & UGE-200, UGE-3M, UGE-5M, UGE-9M & New York \\
\hline XZERES (partial) & 442 & Oregon \\
\hline \multicolumn{3}{|c|}{ Wind Turbines Greater than $100 \mathrm{~kW}$ in U.S. Distributed Projects } \\
\hline Gamesa & G52-850 & Spain \\
\hline GE Renewable Energy & $1.7-103,2.85-103,1.85-87$ & United States \\
\hline Goldwind & GW87/1500 & China \\
\hline RockWind Venture Partners & Refurbished NEG Micon NM48 & United States \\
\hline Vergnet & GEV MP-R & France \\
\hline
\end{tabular}

\section{APPENDIX B METHODOLOGY}

The Pacific Northwest National Laboratory (PNNL) team issued data requests to more than 230 distributed wind manufacturers, suppliers, developers, installers, operations and maintenance (O\&M) providers, state and federal agencies, utilities, and other stakeholders, and compiled responses and information from the sources listed in the Acknowledgments section to tabulate the deployed United States and exported distributed wind generation capacity and associated statistics as of the end of 2015.

A project database was created to capture all known projects installed in 2015. For distributed wind projects using turbines greater than $100 \mathrm{~kW}$, the PNNL team reviewed the American Wind Energy Association's (AWEA's) database and assessed these projects on a per project basis to determine if they met the U.S. Department of Energy definition of distributed wind and should therefore be included in the distributed wind project database. Decommissioned and pending projects were not included in the cumulative tally, based on operational status noted in the AWEA database; however, the cumulative figures principally represent annual capacity additions rather than confirmed operating installations. For projects using small wind turbines (up through $100 \mathrm{~kW}$ ), project records were obtained directly from manufacturers and suppliers,
O\&M providers, utilities, and agencies through e-mail contact, phone interviews, or both.

All records were compiled in the project database with a row for each 2015 project reported. Sales and installation reports from manufacturers, dealers, and developers were crossreferenced with records provided by agencies and installers to identify and combine information from duplicate records. Notes were made in instances of conflicting information (e.g., incentive award amounts, installed costs, and installation dates) as to which sources were used. Small wind turbine sales for which there are project-specific records were added to the project database, but most of the 2015 small wind units sold were not tracked on a project basis.

The PNNL team also reviewed and cross-checked wind project listings published by Open Energy Information, Federal Aviation Administration, U.S. Geological Survey, U.S. Energy Information Administration, U.S. Environmental Protection Agency, and other sources. Installation dates for any projects identified that were not already in AWEA records or reported by manufacturers or agencies were verified and added to the project database. Projects reported for 2015 were cross-checked against previous records to avoid double counting. 
For small wind turbines, this study reports capacity figures for the same calendar year as the reported sales by the manufacturers and suppliers for the purpose of tallying annual deployed capacity. However, some installations occur after the calendar year in which the wind turbines were sold. U.S. sales presence is defined as manufacturers and suppliers documenting at least one sale in the United States in 2015. For turbines greater than $100 \mathrm{~kW}$, the annual deployed capacity is the sum of the distributed wind projects from the AWEA database for the calendar year.

The total number of small wind turbine units, total capacity deployed, and the estimated investment value were based on manufacturers' sales reports.

Cross-referencing data sources allows for greater certainty, but a data gap remains regarding the tally of units and capacity deployed per state compared to the small wind sales records because the majority of small wind units sold are not tracked on a project basis. All project records are used to allocate capacity values across the states, and project records from agency reports were the primary source for the state breakdowns of small wind turbine capacity.

The 2015 Distributed Wind Market Report is the DOE's fourth annual report. Project records from this and past years, along with other collected data, are being consolidated to produce a master database. When known, decommissioned turbines will be removed from the master database. Capacity figures and state allocations may be adjusted in the future as a result of this master database effort.

Incentive payments and reports can lag behind or pre-date sales reports. This report tallies and reports incentive payments for the year in which they were granted, regardless of time of installation, using the best information available at the time of publication. Projects that receive U.S. Department of Agriculture Rural Energy for America Program grants are recorded in the year the grant is awarded, although they may not be installed for up to two years after the grant.
The PNNL team used a variety of public (as listed in the Acknowledgments section) and some private sources of data to compile the installed costs. In some instances, installed cost figures are estimated based on reported incentive values.

Quantitative data requested for 2015 included the number of units sold of each model both in and out of the United States, capacity installed, project locations (city or county and coordinates), estimated installed costs and O\&M costs per year, production data or estimates, installer or developer, power purchaser/utility, tower heights and types, top export markets, application type, breakdowns of project and wind turbine cost components, and employment estimates.

Qualitative questions included details about funding available, project financing mechanisms, interconnection types, ownership structures, solar-specific incentives and installations, and remanufacturing. The level to which all of these questions were answered varied among responders, thus sample sizes are included with certain analysis presentations as needed.

Levelized cost of energy (LCOE) calculations in Section 7.0 used the following formula ${ }^{22}$ :

$$
\mathrm{LCOE}=\frac{(\mathrm{FCR} \times \mathrm{ICC})}{\mathrm{AEPnet}}+\mathrm{AOE}
$$

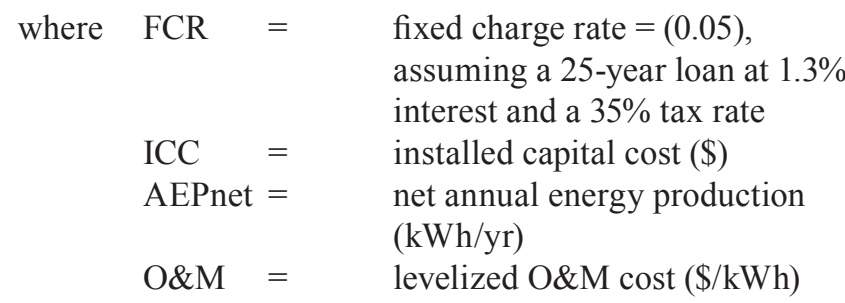

\footnotetext{
${ }^{22}$ NREL's LCOE formula includes a levelized replacement cost that is excluded here.
} 



\title{
RESOURCES
}

\author{
AMERICAN WIND ENERGY ASSOCIATION \\ awea.org
}

DATABASE OF STATE INCENTIVES FOR RENEWABLES \& EFFICIENCY

dsireusa.org

DISTRIBUTED WIND ENERGY ASSOCIATION

distributedwind.org

DISTRIBUTED WIND POLICY TOOL

windpolicytool.org

INTERSTATE TURBINE ADVISORY COUNCIL

cesa.org/projects/ITAC/itac-unified-list-of-wind-turbines/

INTERTEK SMALL WIND CERTIFICATION PROGRAM DIRECTORY

intertek.com/wind/small/directory/

JOBS AND ECONOMIC DEVELOPMENT IMPACT MODELS

nrel.gov/analysis/jedi/

LAWRENCE BERKELEY NATIONAL LABORATORY

Ibnl.gov

NATIONAL RENEWABLE ENERGY LABORATORY

nrel.gov

PACIFIC NORTHWEST NATIONAL LABORATORY

pnnl.gov

SMALL WIND CERTIFICATION COUNCIL

smallwindcertification.org

U.S. DEPARTMENT OF ENERGY WIND PROGRAM

energy.gov/eere/wind 